OLASOLO, Héctor; CANOSA, Jannluck. "La Responsabilidad del Superior en el Acuerdo de Paz en Colombia a la luz del Derecho Internacional".

Polít. crim. Vol. 13, No 25 (Julio 2018) Art. 12, pp. 444-500.

[http://www.politicacriminal.cl/Vol_13/n_25/Vol13N25A12.pdf]

\title{
La Responsabilidad del Superior en el Acuerdo de Paz en Colombia a la luz del Derecho Internacional ${ }^{\bullet}$
}

\section{Superior Responsibility in the Colombian Peace Agreement in light of International Law}

\author{
Héctor Olasolo •• \\ Universidad del Rosario (Colombia) \\ hectorolasolo@gmail.com \\ Jannluck Canosa Cantor ${ }^{\bullet \bullet}$ \\ Universidad del Rosario (Colombia) \\ Canosa.jannluck@gmail.com
}

\section{Resumen}

El presente trabajo compara la regulación de la Responsabilidad de los Superiores Jerárquicos en el Derecho Internacional, en particular en el Derecho Internacional Penal y Humanitario, y su tratamiento en el Derecho colombiano, con particular atención al Acuerdo de Paz entre el Gobierno de Colombia y las FARC y al Acto Legislativo 01/2017.

- El presente trabajo hace parte de los siguientes proyectos de investigación: (i) La función de los órganos judiciales y arbitrales internacionales en la ejecución de un eventual acuerdo de paz en Colombia fruto de la renegociación resultante del Referéndum del 2 de octubre de 2016; y (ii) Principios de armonización entre la función y alcance de la justicia y las demandas surgidas en los procesos políticos de transición. Ambos proyectos se encuentran adscritos a la línea de investigación Crítica al derecho internacional desde fundamentos filosóficos, del Grupo de Investigación de Derecho Internacional de la Facultad de Jurisprudencia de la Universidad del Rosario, Bogotá, Colombia. Los proyectos son financiados por la Dirección de Investigación e Innovación de la Universidad del Rosario y su Facultad de Jurisprudencia.

- Licenciado y doctor en Derecho por la Universidad de Salamanca (España); Maestría en Derecho por la Universidad de Columbia (EE.UU). El Prof. Olasolo Alonso es actualmente catedrático de Derecho internacional en la Universidad del Rosario (Colombia), donde dirige su Clínica Jurídica Internacional y el Anuario Iberoamericano de Derecho Internacional Penal (ANIDIP). Es profesor ad hoc de la Universidad de La Haya para las Ciencias Aplicadas (Holanda) y preside desde 2011 el Instituto Iberoamericano de la Haya para la Paz, los Derechos Humanos y la Justicia Internacional (Holanda). El Prof. Olasolo Alonso se ha desempeñado también como catedrático de Derecho Internacional Penal en la Universidad de Utrecht (Holanda, 2010-2012), magistrado auxiliar de la Corte Penal Internacional (2004-2010), miembro de la Fiscalía del Tribunal Internacional Penal para la ex Yugoslavia (2002-2004 y asesor jurídico de la delegación española en la Comisión Preparatoria de la Corte Penal Internacional (1999-2002). Ha sido también asesor externo del Tribunal Especial para el Líbano, miembro del Roster de Juristas de Reconocido Prestigio de la Organización de las Naciones Unidas para el Nombramiento de Magistrados Internacionales en las Salas Especiales de los Tribunales de Camboya, perito ante la Corte Inter-Americana de Derechos Humanos.

- Abogado de la Universidad del Rosario (Colombia). En la actualidad es Joven Investigador de la Facultad de Jurisprudencia de la Universidad del Rosario. 
Polít. crim. Vol. 13, No 25 (Julio 2018) Art. 12, pp. 444-500.

[http://www.politicacriminal.cl/Vol_13/n_25/Vol13N25A12.pdf]

Esta comparación permite identificar toda una serie de diferencias, que son especialmente significativas en lo que se refiere a su aplicación a los agentes del Estado, y que generan espacios de impunidad con respecto a los superiores militares y civiles que incumplen sus obligaciones de prevenir, reprimir o someter a la autoridad competente los crímenes internacionales por los que son responsables sus subordinados. Ante esta situación, se presentan un conjunto de propuestas relativas a las fuentes normativas, el ámbito de aplicación y los elementos de la Responsabilidad del Superior, que se dirigen a reducir estos espacios de impunidad, en el entendido de que, de no abordarse adecuadamente los problemas identificados, corresponderá a la Fiscalía de la Corte Penal Internacional determinar si procede a la apertura de una investigación sobre la situación en Colombia, cuyo fin sería adelantar actuaciones penales contra aquellos agentes estatales que sean considerados "máximos responsables" de crímenes de la jurisdicción material de la CPI, y en particular de aquellas ejecuciones extrajudiciales denominadas "falsos positivos".

Palabras clave: Derecho Internacional Penal, Corte Penal Internacional, Jurisdicción Especial para la Paz, Responsabilidad del Superior, Acuerdo de Paz en Colombia, FARC, Falsos Positivos.

\begin{abstract}
This article compares the regulation of Superior Responsibility in International Law and its treatment under Colombian Law, with particular attention to the Peace Agreement between the Colombian Government and the FARC, and Legislative Act 01/2017, which implements the Peace Agreement. This comparison shows a whole series of differences, which are especially significant for the application of Superior Responsibility to State agents. They are likely to generate significant impunity gaps for military and civilian superiors, who failed to comply with their obligations to prevent, suppress or submit to the competent authority the international crimes for which their subordinates are responsible. In light of this situation, a set of proposals regarding the normative sources, the scope of application and the elements of Superior Responsibility are put forward. They aim at reducing the impunity gaps, in the understanding that, if the problems identified are not properly addressed, the Prosecutor of the International Criminal Court will have to decide whether to open an investigation into the situation in Colombia to investigate and prosecute the most responsible State agents for ICC crimes (in particular, for those extrajudicial killings referred to as "false positives").
\end{abstract}

Keywords: International Criminal Law, International Criminal Court, Special Jurisdiction for Peace, Superior Responsibility, Peace Agreement in Colombia, FARC, False Positives.

\title{
1. Introducción.
}

El 24 de noviembre de 2016 se firmó en el Teatro Colon de Bogotá el Acuerdo Final para la Terminación del Conflicto y la Construcción de una Paz Estable y Duradera (Acuerdo) entre el Gobierno de Colombia y el grupo armado conocido como Fuerzas Armadas 
OLASOLO, Héctor; CANOSA, Jannluck. "La Responsabilidad del Superior en el Acuerdo de Paz en Colombia a la luz del Derecho Internacional".

Revolucionarias de Colombia - Ejército del Pueblo (FARC-EP). ${ }^{1}$ Con este acto, en el cual se presentó un texto actualizado con varias correcciones al texto inicialmente firmado por las partes el 26 de septiembre del mismo año (Versión Inicial del Acuerdo), que había sido rechazado por un $50.2 \%$ de los votantes en el referendo del 2 de octubre de $2016,{ }^{2}$ se cerró la etapa de negociación que buscaba poner fin al conflicto armado entre el Gobierno de Colombia y las FARC-EP.

El Acuerdo creó el llamado "Sistema Integral de Verdad, Justicia, Reparación y No Repetición", que establece, entre otras instituciones, la Jurisdicción Especial para la Paz (JEP), entidad encargada de satisfacer el derecho de las víctimas a la justicia. ${ }^{3}$ La JEP tiene por objeto, por un lado, esclarecer y sancionar las conductas constitutivas de graves violaciones al Derechos Internacional de los Derechos Humanos (DIDH) o al Derecho Internacional Humanitario (DIH) cometidas "con ocasión, o en relación directa o indirecta con el conflicto armado"; y, por otro lado, decidir sobre la concesión de admitías, indultos y otros beneficios recogidos en el Acuerdo. ${ }^{4}$

El Acuerdo ${ }^{5}$ prevé también un trato "diferencial y equitativo" para los agentes del Estado, incluidos los miembros de las fuerzas armadas y de la policía de Colombia (Fuerza Pública), que se ha tratado de justificar sobre la base de que sus acciones "[...] se presumen legales. Por consiguiente, no se pueden equiparar con las de la guerrilla". ${ }^{6}$

Sin embargo, su incorporación al Acuerdo y al Acto Legislativo 01/2017 a través del cual se implementa normativamente el Acuerdo en Colombia, ${ }^{7}$ se debe en última instancia a que militares y policías han participado en numerosas infracciones del DIDH y el DIH. Como señala el Centro de Memoria Histórica, las violaciones de derechos y ataques contra la población civil realizadas directamente por miembros de la Fuerza Pública en el marco del conflicto armado se aproximan al $17 \%$ del total de los crímenes cometidos. ${ }^{8}$ Todo ello sin

${ }^{1}$ GOBIERNO DE COLOMBIA Y FARC-EP, Acuerdo Final para la Terminación del Conflicto de una Paz Estable y Duradera, firmado el 24 de noviembre de 2016. Disponible en: https://www.mesadeconversaciones.com.co/sites/default/files/acuerdo-final-1473286288.pdf [fecha de consulta 23/07/2017].

${ }^{2}$ Colombia: ganó el "NO" en el plebiscito por los acuerdos de paz con las FARC [en línea]. BBC Mundo. 2 de octubre de 2016. [Fecha de consulta: 23 de julio de 2017]. Disponible en http://www.bbc.com/mundo/noticias-america-latina-37537187.

${ }^{3}$ GOBIERNO DE COLOMBIA Y FARC-EP, Acuerdo de 24 de noviembre de 2016, cit. nota n ${ }^{\circ}$ 1, pp. 143.

${ }^{4}$ GOBIERNO DE COLOMBIA Y FARC-EP, Acuerdo de 24 de noviembre de 2016, cit. nota ${ }^{\circ}$ 1, pp. 145. Sobre la relación entre el Acuerdo y la lucha contra la impunidad ver: LOYO, Joana, "La justicia transicional en Colombia: ¿Un instrumento creado para erradicar la impunidad?" Anuario Iberoamericano de Derecho Internacional Penal, Vol. 5, (2017), pp. 32-61,p. 40 et seq.

${ }^{5}$ GOBIERNO DE COLOMBIA Y FARC-EP, Acuerdo de 24 de noviembre de 2016, cit. nota n ${ }^{\circ} 1$, pp. 149.

${ }^{6}$ GOBIERNO DE COLOMBIA, Aplicación de la Jurisdicción Especial para la Paz a los agentes del Estado. 19 de diciembre 2015.20 Disponible http://es.presidencia.gov.co/saladeprensa/Documents/JEP\%20para\%20agentes\%20del\%20Estado\%20.pdf. [Fecha de consulta: $14 / 08 / 2017$ ]

${ }^{7}$ Acto Legislativo 01/2017. Por medio del cual se crea un título de disposiciones transitorias de la Constitución para la terminación del conflicto armado y la construcción de una paz estable y duradera y se dictan otras disposiciones. Diario Oficial de la República de Colombia, No. 50196 de 4 de abril de 2017

${ }^{8}$ CENTRO NACIONAL DE MEMORIA HISTÓRICA, iBasta ya! Colombia: Memorias de guerra y dignidad resumen [en línea]. Colombia: Centro Nacional de Memoria Histórica, 2014 [fecha de consulta: 
Polít. crim. Vol. 13, № 25 (Julio 2018) Art. 12, pp. 444-500.

[http://www.politicacriminal.cl/Vol_13/n_25/Vol13N25A12.pdf]

incluir los múltiples hechos punibles producto de su connivencia con grupos paramilitares, tal y como ha afirmado en varias oportunidades la Corte Interamericana de Derechos Humanos (Corte IDH). ${ }^{9}$

Estrechamente relacionado con el trato diferenciado y equitativo previsto para los agentes del Estado, se encuentra el objeto del presente trabajo: la responsabilidad penal de los superiores jerárquicos por los crímenes internacionales cometidos por sus subordinados (Responsabilidad del Superior). De hecho, la regulación contenida en el Acuerdo sobre esta forma de responsabilidad no es la misma para los superiores jerárquicos de las FARC-EP que para los agentes del Estado, lo que es fruto de la "vital importancia" que para las Fuerzas Armadas y la Asociación Colombiana de Oficiales Retirados de las Fuerzas Militares (ACORE) tiene la misma, y a su exigencia, con el pretendido propósito de evitar una "cacería de brujas" contra los comandantes militares, de que se diera un trato diferenciado y cuidadosamente reglamentado en su aplicación a los miembros de la Fuerza Pública. ${ }^{10}$

En este contexto, y teniendo en cuenta el examen preliminar que la Fiscalía de la Corte Penal Internacional (CPI) ha venido realizando sobre la situación en Colombia desde $2005 .{ }^{11}$ y su reciente solicitud al gobierno de Colombia el 9 de julio de 2017 para que investigue y enjuicie a veintitrés generales y seis coroneles por presuntos falsos positivos cometidos por sus subordinados. ${ }^{12}$ el presente trabajo analiza el nivel de correspondencia entre la regulación de la Responsabilidad del Superior (RespSup) en el Derecho Internacional (DI), y en particular en el art. 28 del Estatuto de la Corte Penal Internacional (ECPI), y su tratamiento en el derecho interno Colombiano, especialmente en el Acuerdo y el Acto Legislativo 01/2017 de 4 de abril.

$14 / 08 / 2017]$

Disponible

en

https://www.centrodememoriahistorica.gov.co/descargas/informes2013/bastaYa/resumen-ejecutivo-basta-

ya.pdf. pp. 23-38

${ }^{9}$ Sentencia de fondo, reparaciones y costas, Serie C No. 325, Caso Yarce y otras vs. Colombia, Corte Interamericana de Derechos Humanos, 22 de noviembre de 2016; y Sentencia de fondo, reparaciones y costas, Serie C No. 148, Caso de la Masacre de Ituango vs. Colombia, Corte Interamericana de Derechos Humanos. 1 de julio de 2006.

${ }^{10}$ FUNDACIÓN IDEAS PARA LA PAZ, Especial: Los debates sobre justicia transicional [En línea], 2015, disponible en http://www.ideaspaz.org/especiales/justicia-transicional/farc/descargas/plantillaGuion1.pdf. [fecha de consulta: 14/08/2017]. pp. 5; y VIVANCO, José Miguel, Carta sobre "responsabilidad de mando" en la legislación de implementación del acuerdo de paz [En línea], 25 de enero de 2017, disponible en https://www.hrw.org/es/news/2017/01/25/carta-sobre-responsabilidad-de-mando-en-la-legislacion-deimplementacion-del-acuerdo [fecha de consulta: 14/08/2017]

${ }^{11}$ El examen preliminar de admisibilidad por parte de la Fiscalía de la CPI se encuentra abierto desde 2004.

${ }^{12}$ LEGMANN, Christof. ICC Chief Prosecutor Bensouda Threatens with Intervention in Colombia [en linea], NSNBC. 27 January 2017. [Fecha de consulta: 13 de agosto de 2017]. Disponible en https://nsnbc.me/2017/01/27/icc-chief-prosecutor-bensouda-threatens-intervention-in-colombia/ Vid. también 29 generales y coroneles, en la mira de la CPI por ejecuciones extrajudiciales [en linea], El Espectad or. 9 de Julio de 2017. [Fecha de consulta: 19 de julio de 2017]. Disponible en http://colombia2020.elespectador.com/jep/29-generales-y-coroneles-en-la-mira-de-la-cpi-por-ejecucionesextrajudiciales. Sobre el margen de actuación de la CPI en la lucha contra la impunidad ver: ABELLO, Ana, "El 'margen protector' de la Corte Penal Internacional", Anuario Iberoamericano de Derecho Internacional Penal, Vol. 4, (2015), pp. 124-144. 
OLASOLO, Héctor; CANOSA, Jannluck. "La Responsabilidad del Superior en el Acuerdo de Paz en Colombia a la luz del Derecho Internacional".

Para ello, comenzamos nuestra exposición en la sección II con el análisis de las fuentes, concepto, elementos y naturaleza de la RespSup en el DI. A continuación, en la sección III estudiamos el tratamiento que ha tenido en el Derecho colombiano, haciendo particular hincapié en la ausencia de un tratamiento legislativo autónomo y en los intentos jurisprudenciales de la Corte Constitucional de Colombia y la Sala de Casación Penal de la Corte Suprema de Justicia por equipararla a la comisión por omisión en algunos casos y a la autoría mediata a través de aparatos organizados de poder en otros. Así mismo, analizamos en esta sección la manera en que la RespSup ha sido recogida en la normatividad interna de las fuerzas armadas de Colombia.

Con base en estos precedentes internos, y a la luz de su regulación en el DI, abordamos en la sección IV la regulación de la RespSup en el Acuerdo y el Acto Legislativo 01/2017, dedicando particular atención al análisis de las diferencias identificadas frente al régimen jurídico internacional de esta figura, en particular en lo que se refiere a su aplicación a los agentes del Estado.

Finalmente, en la sección $\mathrm{V}$ presentamos las conclusiones del trabajo, donde se recogen un conjunto de propuestas para enfrentar los problemas identificados en las secciones anteriores, en el entendido de que, de no abordarse adecuadamente, corresponde a la Fiscalía de la CPI determinar si procede la apertura de una investigación sobre la situación en Colombia para, inter alia, adelantar actuaciones contra aquellos agentes del Estado que sean considerados "máximos responsables" de los crímenes internacionales cometidos por la Fuerza Pública en el conflicto armado, y en particular los falsos positivos.

\section{La Responsabilidad del Superior en el Derecho Internacional}

\subsection{Fuentes}

La RespSup tiene sus orígenes en el Derecho Internacional Penal (DIP) y el Derecho Internacional Humanitario. Debido a su estrecha relación con la sanción de crímenes internacionales como los crímenes de guerra o de lesa humanidad, ${ }^{13}$ en el momento de su creación al final de la segunda guerra mundial, no tenía equivalente en los sistemas nacionales. ${ }^{14}$

El caso contra el general japonés Tomoyuki Yamashita, comandante del Ejército Japonés en las Filipinas entre 1944 y 1945, es considerado como el primer precedente de esta figura. La Comisión Militar de los Estados Unidos que lo condenó a muerte justificó su condena por la "omisión en el cumplimiento de su obligación como comandante de controlar las operaciones de los miembros [del ejército] a su cargo, permitiéndoles cometer atrocidades brutales contra el pueblo de los Estados Unidos, sus aliados y dependencias, particularmente Filipinas". ${ }^{15}$

\footnotetext{
${ }^{13}$ PARKS, William, "Command Responsibility for War Crimes", Military Law Review, vol. 62 (1973), pp. 1274-1304; y BASSIOUNI, Mahmoud Cherif, International Criminal Law, Vol III, 3 ed, Leiden: Martinus Nijhoff Publishers, 2008,p. 459

${ }^{14}$ WERLE, Gerhard, Principles of international criminal law, La Haya: TMC Asser press, 2005. p. 368.

${ }^{15}$ Sentencia en el Caso Yamashita, 327 U.S, Corte Suprema de Justicia de los Estados Unidos, 4 de febrero de 1946, p. 14
} 
El caso contra el general Yamashita despertó una gran polémica por que el acusado había dado la orden de evacuar Manila y retirarse a las montañas del norte de Luzón (donde el mismo se instaló), que fue desobedecida por el contraalmirante Iwabuchi Sanji, lo que provocó duros combates en la capital filipina contra las fuerzas norteamericanas atacantes que generaron la muerte de cerca de cien mil civiles filipinos. ${ }^{16} \mathrm{Sin}$ embargo, fue a partir del mismo que comenzó a desarrollarse la RespSup como forma de responsabilidad penal por los crímenes internacionales cometidos por los subordinados, ${ }^{17}$ la cual sería posteriormente utilizada en 1947 y 1948 por el Tribunal Militar establecido en la zona de ocupación norteamericana para condenar a superiores jerárquicos civiles y militares del régimen nacional socialista alemán en los casos del Alto Mando, ${ }^{18}$ los Rehenes ${ }^{19}$ y el Personal Médico. ${ }^{20}$

Con base en estos precedentes, el DIH desarrolló en 1977 la RespSup a través del art. 86 (2) del Protocolo Adicional I a los Convenios de Ginebra. De acuerdo con esta disposición, "[e]l hecho de que la infracción de los Convenios o del presente Protocolo haya sido cometida por un subordinado no exime de responsabilidad penal o disciplinaria, según el caso, a sus superiores, si éstos sabían o poseían información que les permitiera concluir, en las circunstancias del momento, que ese subordinado estaba cometiendo o iba a cometer tal infracción y si no tomaron todas las medidas factibles que estuvieran a su alcance para impedir o reprimir esa infracción". ${ }^{21}$

Quince años más tarde, la RespSup sería expresamente recogida en los arts. 7(3) del Estatuto del Tribunal Internacional para la ex Yugoslavia (ETIPY) y 6(3) del Estatuto del Tribunal Internacional Penal para Ruanda (ETIPR). ${ }^{22}$ En estas disposiciones, así como en el art. 6(3) del Estatuto de la Corte Especial para Sierra Leona (ECESL) aprobado años después, se establece que "[e]l hecho de que cualquiera de los actos contemplados en los

\footnotetext{
${ }^{16}$ PRÉVOST, Ann Marie, "Race and War Crimes: The 1945 War Crimes Trial of General Tomoyuki Yamashita", Human Rights Quarterly, vol. 14(3), (1992), pp. 303-338, p. 309; y DOWER, John, War without Mercy: Race and Power in the Pacific War, New York: Pantheon Books, 2012.

${ }^{17}$ AMBOS, Kai, "Superior Responsibility”, en CASSESE, Antonio, GAETA, Paola y JONES, John (Eds.), The Rome Statute of The International Criminal Court: A Commentary, Vol. 3, Oxford: Oxford University Press, 2002, pp. 823-872.

${ }^{18}$ Sentencia en el caso contra Wilhelm Von Leeb et al. (conocido como el caso del Alto Mando), U.S Tribunales Militares de Nuremberg, 28 de octubre de 1948. En Trials of War Criminals Tomo X, Washington: Goverment Printing Office, 1950, pp. 3-1238, pp. 542 et seq

${ }^{19}$ Sentencia en el caso contra Wilhelm Von Leeb et al. (conocido como el caso del Alto Mando), U.S Tribunales Militares de Nuremberg, 28 de octubre de 1948. En Trials of War Criminals Tomo X, Washington: Goverment Printing Office, 1950, pp. 3-1238 pp. 1236 et seq.

${ }^{20}$ Sentencia en el caso contra Karl Brand et al. (conocido como el caso del Personal Médico), U.S Tribunales Militares de Nuremberg, 20 de agosto de 1947. En Trials of War Criminals Tomo II, Washington: Goverment Printing Office, 1950, pp. 1-354, pp. 187 et seq

21 PILlOUD, Claude; SANDOZ, Yves; SWINARSKI, Christoph; y ZIMMERMANN, Bruno (eds.), Commentary on the Additional Protocols: of 8 June 1977 to the Geneva Conventions of 12 August 1949, La Haya: ICRC/ Martinus Nijhoff Publishers (1987), párrs. 3543 et seq

${ }^{22}$ Resolución 827 del Consejo de Seguridad de la Organización de Naciones Unidas, Estatuto del Tribunal Internacional Penal para ex Yugoslavia, 25 de mayo de 1993; y Resolución 955 del Consejo de Seguridad de la Organización de Naciones Unidas, Estatuto del Tribunal Internacional Penal para Ruanda, 8 de noviembre de 1994.
} 
OLASOLO, Héctor; CANOSA, Jannluck. "La Responsabilidad del Superior en el Acuerdo de Paz en Colombia a la luz del Derecho Internacional”.

artículos 2 a 5 del presente Estatuto haya sido cometido por un subordinado, no libera a su superior de su responsabilidad penal si sabía o tenía razones para saber que el subordinado se aprestaba a cometer ese acto o ya lo hizo, y el superior no tomó las medidas necesarias y razonables para impedir que dicho acto no fuera cometido, o para castigar a los autores". Sin embargo, habría que esperar hasta la entrada en vigor el 1 de julio de 2002 del ECPI para obtener en su art. 28 la definición más elaborada que existe hasta el momento de esta forma de responsabilidad penal. ${ }^{23}$

Junto a su regulación convencional en el DIP y el DIH, la RespSup forma parte también del DI consuetudinario. Así, la norma 153 del estudio del Comité Internacional de la Cruz Roja (CICR) sobre el DIH consuetudinario señala que "los jefes y otros mandos superiores son penalmente responsables de los crímenes de guerra cometidos por sus subordinados [...]". ${ }^{24}$ El CICR llegó a esta conclusión con base en su aplicación práctica por el TIPY, el TIPR y diversos tribunales nacionales. ${ }^{25}$

La RespSup ha sido también recogida por la jurisprudencia del Tribunal Europeo de Derechos Humanos (TEDH), al señalar que, en el marco de la investigación de crímenes de guerra, para que una investigación resulte suficiente conforme al art. 2 de la Convención Europea de Derechos Humanos (que protege el derecho a la vida), se debe diferenciar entre las responsabilidades de los subordinados y las de los superiores, de acuerdo a la regulación que de las mismas realiza el DIP. ${ }^{26}$

En cuanto al Sistema Interamericano de Derechos Humanos (SIDH), si bien no existe un pronunciamiento expreso de sus órganos principales sobre la RespSup, lo cierto es que la Corte IDH, en virtud del análisis de las distintas obligaciones internacionales de los Estados parte del SIDH con el fin de interpretar el contenido de sus deberes conforme a la

\footnotetext{
${ }^{23}$ La RespSup es definida en el art. 28 del ECPI de la siguiente manera: “Además de otras causales de responsabilidad penal de conformidad con el presente Estatuto por crímenes de la competencia de la Corte:

a) El jefe militar o el que actúe efectivamente como jefe militar será penalmente responsable por los crímenes de la competencia de la Corte que hubieren sido cometidos por fuerzas bajo su mando y control efectivo, o su autoridad y control efectivo, según sea el caso, en razón de no haber ejercido un control apropiado sobre esas fuerzas cuando: i) Hubiere sabido o, en razón de las circunstancias del momento, hubiere debido saber que las fuerzas estaban cometiendo esos crímenes o se proponían cometerlos; y ii) No hubiere adoptado todas las medidas necesarias y razonables a su alcance para prevenir o reprimir su comisión o para poner el asunto en conocimiento de las autoridades competentes a los efectos de su investigación y enjuiciamiento.

b) En lo que respecta a las relaciones entre superior y subordinado distintas de las señaladas en el apartado a), el superior será penalmente responsable por los crímenes de la competencia de la Corte que hubieren sido cometidos por subordinados bajo su autoridad y control efectivo, en razón de no haber ejercido un control apropiado sobre esos subordinados, cuando: i) Hubiere tenido conocimiento o deliberadamente hubiere hecho caso omiso de información que indicase claramente que los subordinados estaban cometiendo esos crímenes o se proponían cometerlos; ii) Los crímenes guardaren relación con actividades bajo su responsabilidad y control efectivo; y iii) No hubiere adoptado todas las medidas necesarias y razonables a su alcance para prevenir o reprimir su comisión o para poner el asunto en conocimiento de las autoridades competentes a los efectos de su investigación y enjuiciamiento".

24 HENCKAERTS, Jean; DOSWALD-BECK, Louise (Dirs.), El derecho internacional humanitario consuetudinario, Ginebra: CICR, 2007, Regla 153, pp 623 et seq.

${ }^{25}$ HENCKAERTS, El derecho internacional, cit. nota ${ }^{\circ} 24$, pp. 663 y 664

${ }^{26}$ Sentencia de fondo en el caso Jelic c. Croacia, Aplicación no. 57856/11, Corte Europea de Derechos Humanos, 12 de Junio de 2014, párr. 88-90.
} 
Polít. crim. Vol. 13, № 25 (Julio 2018) Art. 12, pp. 444-500.

[http://www.politicacriminal.cl/Vol_13/n_25/Vol13N25A12.pdf]

Convención Americana de Derechos Humanos $(\mathrm{CADH}),{ }^{27}$ ha subrayado la utilidad de las normas del DIH, e incluso ha recurrido a ciertas disposiciones de los Protocolos Adicionales a los Convenios de Ginebra para determinar el alcance de la responsabilidad de los Estados en relación con los derechos de las víctimas de crímenes internacionales ocurridos durante los conflictos armados, ${ }^{28}$ Además, en su práctica hermenéutica, la Corte IDH ha seguido de cerca las interpretaciones del TEDH en materia de estándares de investigación judicial. $^{29}$ En consecuencia, es razonable interpretar que entre las obligaciones impuestas por la $\mathrm{CADH}$ a los Estados partes se encuentra el deber de investigar la RespSup en relación con las graves violaciones de la $\mathrm{CADH}$ cometidas en el contexto de un conflicto armado. ${ }^{30}$

\subsection{Concepto}

La RespSup se construye en torno al principio de responsabilidad penal por omisión cuando existe una obligación jurídica de actuar. ${ }^{31} \mathrm{Su}$ fundamento se encuentra en la obligación jurídica que, conforme al DIP y al DIH, tiene todo superior, civil o militar, en razón del control efectivo que despliega sobre sus subordinados, de adoptar las medidas necesarias y razonables a su disposición para prevenir, reprimir y someter a las autoridades competentes los crímenes internacionales cometidos por los mismos. ${ }^{32}$ Con ello se busca limitar la comisión de este tipo de crímenes. ${ }^{33}$

En relación con los superiores militares, este fundamento ha sido expuesto con claridad por el TIPY en el caso Hadzihasanovic et al., al afirmar que la RespSup se encuentra arraigada en el entendimiento de que "en virtud de la autoridad que portan, los comandantes están preparados para ejercer control sobre sus tropas y las armas que utilizan; más que cualquier

27 Opinión Consultiva OC-1/82 "Otros tratados", Corte Interamericana de Derechos Humanos, 24 de septiembre de 1982

${ }^{28}$ Sentencia de fondo, reparaciones y costas, Serie C No. 287, Caso Rodríguez Vera y otros (Desaparecidos del Palacio de Justicia) vs. Colombia, Corte Interamericana de Derechos Humanos, 14 de noviembre de 2014, párr. 39

${ }^{29}$ Sentencia de fondo, reparaciones y costas, Serie C No. 196, Caso Kawas Fernández vs. Honduras, Corte Interamericana de Derechos Humanos 3 de abril de 2009.

${ }^{30}$ APONTE, Alejandro, "El Sistema Interamericano de Derechos Humanos y el Derecho Internacional Humanitario: una relación problemática", en GRUPO LATINOAMERICANO DE ESTUDIOS SOBRE DERECHO PENAL INTERNACIONAL, Sistema Interamericano de Protección de los Derechos Humanos y Derecho Penal Internacional, Montevideo: Fundación Konrad-Adenauer, 2010, pp. 125-170, p.160.

${ }^{31}$ Decisión de confirmación de cargos, ICC-01/05-01/08-424, The Prosecutor v. Jean-Pierre Bemba Gombo, Sala de Cuestiones Preliminares II, Corte Penal Internacional, 3 de julio de 2009, párr. 405; Sentencia sala de primera instancia, IT-96-21, The prosecutor v. Mucic et al (Celebici case), Tribunal Penal Internacional para la Ex Yugoslavia, 20 de febrero de 2001, párr. 334; Sentencia sala de primera instancia, IT-01-47, The prosecutor v. Hadzihasanovic \& Kubura, Tribunal Penal Internacional para la Ex Yugoslavia, 15 de marzo de 2006, párr. 75; Sentencia Sala de Primera Instancia, IT-01-48, The Prosecutor v. Halilovic, Tribunal Penal Internacional para la Ex Yugoslavia, 16 de noviembre de 2005, párr. 54. Véase también PILLOUD, Commentary on, cit. nota ${ }^{\circ} 21$, párr. 3543 et seq.

${ }^{32}$ OLASOLO, Héctor, Tratado de Autoría y Participación en Derecho Penal Internacional, Valencia: Tirant lo Blanch, 2013, p. 767.

${ }^{33}$ ACEVEDO, Juan, “La Responsabilidad del Superior 'sensu estricto' por Crímenes de Guerra en el Derecho Internacional Contemporáneo” Revista International Law, Vol. 10 (2007), pp. 153-198. 
OLASOLO, Héctor; CANOSA, Jannluck. "La Responsabilidad del Superior en el Acuerdo de Paz en Colombia a la luz del Derecho Internacional".

otra persona pueden evitar infracciones creando el estado mental apropiado, asegurando el uso racional de los medios de combate y manteniendo disciplina". ${ }^{34}$

Conviene subrayar desde un principio que la construcción de la RespSup por la CPI varía con respecto a la que se puede encontrar en el TIPY, el TIPR y la CESL, en virtud de la diferente clasificación que realizan de las obligaciones que impone a los superiores el DIP y el DIH. Si bien se trata de una diferencia más nominal que material, es importante tenerla en consideración desde un primer momento para evitar confusiones.

De esta manera, los estatutos y jurisprudencia del TPIY, el TPIR y la CESL desarrollan la RespSup a la luz del contenido de las siguientes obligaciones jurídicas del superior: (i) prevenir la comisión de crímenes internacionales por sus subordinados (lo que incluye también el deber de poner fin a los que se estén cometiendo); y (ii) castigar a los subordinados que hayan estado involucrados en los mismos (lo que supone a su vez el deber de enviar la cuestión a las autoridades competentes cuando no se tenga la facultad jurídica para castigar). ${ }^{35}$

Por su parte, el art. 28 ECPI y la jurisprudencia de la CPI construyen la RespSup en torno al contenido de las obligaciones jurídicas del superior de: (i) prevenir la comisión de crímenes internacionales por sus subordinados, (ii) reprimir la comisión de dichos crímenes, en el sentido de poner fin a los que se estén cometiendo y castigar a los subordinados que hayan estado involucrados en los mismos; y (iii) enviar la cuestión a las autoridades competentes cuando no se tenga la facultad jurídica para castigar. ${ }^{36}$ Dada la mayor relevancia para Colombia del ECPI, del cual es parte desde el 1 de noviembre de 2002, seguimos en el presente trabajo esta última aproximación.

Las obligaciones jurídicas de prevenir, reprimir y enviar la cuestión a las autoridades competentes constituyen obligaciones jurídicas con autonomía propia, que surgen en distintos momentos y cuyo incumplimiento no puede resultar compensado por el cumplimiento de las demás. Esto significa, por ejemplo, que la responsabilidad penal por omitir el deber de prevenir no puede ser eximida por el cumplimiento de los deberes de reprimir y enviar la cuestión a la autoridad competente. ${ }^{37}$

\footnotetext{
${ }^{34}$ Sentencia sala de primera instancia, IT-01-47, The prosecutor v. Hadzihasanovic \& Kubura, Tribunal Penal Internacional para la Ex Yugoslavia, 15 de marzo de 2006, párr. 66; Sentencia Sala de Primera Instancia, IT01-48, The Prosecutor v. Halilovic, Tribunal Penal Internacional para la Ex Yugoslavia, 16 de noviembre de 2005, párr. 85.

${ }^{35}$ Sentencia de Primera Instancia, ICTR-98-44A, The Prosecutor v. Kajelijeli, Tribunal Penal Internacional para Ruanda, 1 de diciembre de 2003, párr. 740; Sentencia Sala de Primera Instancia, IT-01-48, The Prosecutor v. Halilovic, Tribunal Penal Internacional para la Ex Yugoslavia, 16 de noviembre de 2005, párr. 87; Sentencia sala de primera instancia, IT-01-47, The prosecutor v. Hadzihasanovic \& Kubura, Tribunal Penal Internacional para la Ex Yugoslavia, 15 de marzo de 2006, párr. 127. Vid. también, OLASOLO, Tratado de Autoría, cit. nota n ${ }^{\circ} 32$, pp. 768-769.

${ }^{36}$ Decisión de confirmación de cargos, ICC-01/05-01/08-424, The Prosecutor v. Jean-Pierre Bemba Gombo, Sala de Cuestiones Preliminares II, Corte Penal Internacional, 3 de julio de 2009, párrs. 436-442. Vid. también, OLASOLO, Tratado de Autoría, cit. nota n ${ }^{\circ}$ 32, pp. 768-769.

${ }_{37}$ Decisión de confirmación de cargos, ICC-01/05-01/08-424, The Prosecutor v. Jean-Pierre Bemba Gombo, Sala de Cuestiones Preliminares II, Corte Penal Internacional, 3 de julio de 2009, párr. 336. Vid. también, Sentencia de Primera Instancia, ICTR-95-1-T, The Prosecutor v. Kayishema, Tribunal Penal Internacional
} 
En cuanto al momento de su nacimiento, la obligación de prevenir surge con anterioridad a la comisión del crimen internacional por los subordinados y sólo puede verse satisfecha antes de que se produzca su consumación. ${ }^{38}$ Por su parte, la obligación de reprimir, en lo que se refiere al deber de poner fin a la comisión del delito, nace únicamente cuando el crimen internacional comienza a ser ejecutado, ${ }^{39}$ mientras que en lo que se refiere al deber de castigar surge una vez que se ha consumado. ${ }^{40}$ Finalmente, la obligación de enviar la cuestión a las autoridades competentes surge así mismo tras la consumación del crimen internacional. ${ }^{41}$

Dado que el DIP y el DIH imponen estas obligaciones jurídicas a todos los superiores civiles y militares, la responsabilidad penal por omisión en su cumplimiento no se atribuye únicamente al superior inmediato de los autores materiales de los crímenes internacionales, sino que puede extenderse a varios superiores, y llegar, siguiendo la cadena de mando, hasta los más altos dirigentes. ${ }^{42}$

\subsection{Elementos de la Responsabilidad del Superior}

Las diferencias analizadas en la sección anterior con respecto a la clasificación de las obligaciones jurídicas del superior son el origen de ciertas variaciones en los elementos de la RespSup en el TIPY, el TIPR y la CESL, por un lado, y en la CPI por otro. Así, el TIPY ha subrayado en el caso Oric que para que un superior incurra en responsabilidad penal conforme al art. 7(3) ETPIY: [...] además de establecerse más allá de toda duda razonable que su subordinado es penalmente responsable, deben probarse más allá de toda duda razonable los siguientes elementos: (i) la existencia de una relación superior-subordinado; (ii) que el superior sabía, o tenía razones para saber, que su subordinado iba a cometer un delito, o lo había cometido; y (iii) que el superior no tomó las medidas necesarias y razonables para evitar la conducta punible de su subordinado, o para castigarlo". ${ }^{43}$

para Ruanda, 21 de mayo de 1999; Sentencia de Primera Instancia, IT-95-15, The Prosecutor v. Blaskic, Tribunal Penal Internacional para la ex Yugoslavia, 3 de marzo de 2000, párr. 515; Sentencia sala de primera instancia, IT-01-47, The prosecutor v. Hadzihasanovic \& Kubura, Tribunal Penal Internacional para la Ex Yugoslavia, 15 de marzo de 2006, párr. 126.

${ }^{38}$ Sentencia de Primera Instancia, ICTY-01-42-T, The Prosecutor v. Strugar, Tribunal Penal Internacional para la ex Yugoslavia, 31 de enero de 2005; y Sentencia Sala de Primera Instancia, IT-01-47, The prosecutor v. Hadzihasanovic \& Kubura, Tribunal Penal Internacional para la Ex Yugoslavia, 15 de marzo de 2006, párr. 125.

${ }^{39}$ Decisión de confirmación de cargos, ICC-01/05-01/08-424, The Prosecutor v. Jean-Pierre Bemba Gombo, Sala de Cuestiones Preliminares II, Corte Penal Internacional, 3 de julio de 2009, párrs. 439 y 440.

${ }^{40}$ Decisión de confirmación de cargos, ICC-01/05-01/08-424, The Prosecutor v. Jean-Pierre Bemba Gombo, Sala de Cuestiones Preliminares II, Corte Penal Internacional, 3 de julio de 2009, párr. 442.

${ }^{41}$ Decisión de confirmación de cargos, ICC-01/05-01/08-424, The Prosecutor v. Jean-Pierre Bemba Gombo, Sala de Cuestiones Preliminares II, Corte Penal Internacional, 3 de julio de 2009, párr. 442.

${ }^{42}$ Decisión de confirmación de cargos, ICC-01/05-01/08-424, The Prosecutor v. Jean-Pierre Bemba Gombo, Sala de Cuestiones Preliminares II, Corte Penal Internacional, 3 de julio de 2009, párr. 410.

${ }^{43}$ Sentencia de la Sala de Apelación, IT-03-68, The Prosecutor v. Oric, Tribunal Penal Internacional para la ex Yugoslavia, 3 de julio de 2008, párr. 18; ECKHARDT, William, "Command Criminal Responsibility: A Plea for a Workable Standard”. Military Law Review, Vol. 97, (1982), pp. 1-58, pp. 4 y 5. 
OLASOLO, Héctor; CANOSA, Jannluck. "La Responsabilidad del Superior en el Acuerdo de Paz en Colombia a la luz del Derecho Internacional".

Por su parte, la CPI ha afirmado en el caso Bemba que los elementos que han de probarse para que un superior militar incurra en responsabilidad conforme al art. 28(a) ECPI son los siguientes: "[...] (a) el sospechoso debe ser un superior militar, o una persona que actúe efectivamente como tal; (b) el sospechoso debe tener un mando y control efectivo, o una autoridad y control efectivo sobre las fuerzas (subordinados) que cometieron uno o más delitos previstos en los artículos 6 a 8 del Estatuto; (c) los delitos cometidos por sus fuerzas (subordinados) resultaron de la omisión del sospechoso de ejercitar un adecuado control sobre las mismas; (d) el sospechoso conocía, o debido a las circunstancias vigentes al momento, hubiere debido saber, que las fuerzas (subordinados) estaban cometiendo o iban a cometer uno o más delitos previstos en los artículos 6 a 8 del Estatuto; y (e) el sospechoso no adoptó las medidas necesarias y razonables a su disposición para evitar o castigar la comisión de tales delitos, o dejó de informar sobre el asunto a las autoridades competentes para su investigación y enjuiciamiento". ${ }^{44}$

A pesar de las diferencias que parecen existir entre ambas listas de elementos, lo cierto es que un análisis más detallado muestra un alto grado de correspondencia entre los mismos. ${ }^{45}$ Así, los elementos (a) y (b) en Bemba se refieren a distintos aspectos del primer elemento en Oric: la relación superior-subordinado. Además, los elementos (d) y (e) en Bemba se refieren respectivamente al segundo y tercer elemento en Oric. En consecuencia, sólo el elemento (c) en Bemba no tiene correspondencia en Oric, lo que es debido al rechazo por la jurisprudencia del TPIY, el TPIR y la CESL de todo nexo de causalidad en la RespSup. ${ }^{46}$

En consecuencia, se puede afirmar que la RespSup requiere en el DIP la satisfacción de tres elementos principales: (a) la existencia de una relación superior-subordinado; (b) la omisión por el superior de su obligación jurídica de adoptar todas las medidas razonables y necesarias a su disposición para prevenir, reprimir o someter a la autoridad competente los crímenes internacionales de sus subordinados (elemento objetivo); y (c) el conocimiento que el superior tenía o debiera haber tenido de dichos crímenes internacionales (elemento subjetivo). ${ }^{47}$ Además, en el caso de omisiones del deber prevenir, el art. 28 ECPI exige un cuarto elemento consistente en la existencia de un nexo de causalidad entre la omisión del superior y los crímenes internacionales cometidos por sus subordinados. ${ }^{48}$ A continuación, analizaremos brevemente cada elemento.

\footnotetext{
${ }^{44}$ Decisión de confirmación de cargos, ICC-01/05-01/08-424, The Prosecutor v. Jean-Pierre Bemba Gombo, Sala de Cuestiones Preliminares II, Corte Penal Internacional, 3 de julio de 2009, párr. 407.

${ }^{45}$ OLASOLO, Tratado de Autoría, cit. nota n ${ }^{\circ}$ 32, pp. 770-772.

46 Sentencia de la Sala de Apelación, IT-97-25, The Prosecutor v. Krnojelac, Tribunal Penal Internacional para la ex Yugoslavia, 17 de septiembre de 2003, párrs. 170-172; Sentencia de Primera Instancia, IT-95-15, The Prosecutor v. Blaskic, Tribunal Penal Internacional para la ex Yugoslavia, 3 de marzo de 2000, párr. 77; Sentencia de la Sala de Apelación, IT-95-14/2, The Prosecutor v. Kordic \& Cerkez, Tribunal Penal Internacional para la ex Yugoslavia, 17 de diciembre de 2004, párr. 832; Sentencia de la Sala de Apelación, IT-01-47, The Prosecutor v. Hadzihasanovic, Tribunal Penal Internacional para la Ex Yugoslavia, 22 de abril de 2008, párrs. 38-42; Sentencia sala de primera instancia, IT-96-21, The prosecutor v. Mucic et al (Celebici case), Tribunal Penal Internacional para la Ex Yugoslavia, 20 de febrero de 2001, párr. 400; y Sentencia Sala de Primera Instancia, IT-01-48, The Prosecutor v. Halilovic, Tribunal Penal Internacional para la Ex Yugoslavia, 16 de noviembre de 2005, párrs. 75-78.

${ }^{47}$ WERLE, Gerhard, Tratado de Derecho Penal Internacional, 2ed, Valencia: Tirant lo Blanch, 2011, p. 316; BASSIOUNI, International Criminal Law, cit. nota n ${ }^{\circ} 13$, p. 471.

${ }^{48}$ OLASOLO, Tratado de Autoría, cit. nota n ${ }^{\circ} 32$, p. 793
} 


\subsubsection{La existencia de una relación superior-subordinado.}

El primer elemento de la RespSup es la existencia de una relación superior-subordinado entre el superior civil o militar de que se trate y quienes son penalmente responsables por la comisión de crímenes internacionales. ${ }^{49}$ No es necesario identificar individualmente a estos últimos, sino que es suficiente con especificar a qué grupo pertenecían en el momento en que incurrieron en responsabilidad por los hechos punibles, y demostrar la existencia de una relación superior-subordinado entre el superior y dicho grupo. ${ }^{50}$ Así mismo, tampoco es necesario que los subordinados sean autores materiales, autores mediatos o coautores del delito, sino que es suficiente con que sean penalmente responsables bajo cualquiera de las formas de responsabilidad previstas en el art. 25 ECPI $^{51}$ (o en los arts. 7(1) ETIPY, 6 (1) ETIPR o 6 (1) ECESL). En consecuencia, como el TIPY ha señalado en el caso Oric, "[...] se puede sostener la responsabilidad penal de un superior por el hecho de que sus subordinados planeen, instiguen, ordenen, cometan, o de cualquier otra manera cooperen en un delito". 52

La relación superior-subordinado es definida en relación con los superiores militares en el art. 28(a) ECPI de la siguiente manera: “[e]1 jefe militar o el que actúe efectivamente como jefe militar será penalmente responsable por los crímenes de la competencia de la Corte que hubieren sido cometidos por fuerzas bajo su mando y control efectivo, o su autoridad y control efectivo". Por su parte el apartado (b) de la misma disposición añade en relación con los superiores civiles que "[e]n lo que respecta a las relaciones entre superior y subordinado distintas de las señaladas en el apartado a), el superior será penalmente responsable por los crímenes de la competencia de la Corte que hubieren sido cometidos por subordinados bajo su autoridad y control efectivo [...]" siempre y cuando "(ii) [1] os crímenes guardaren relación con actividades bajo su responsabilidad y control efectivo".

En el caso Bemba, la CPI ha interpretado el término "jefe militar" como la persona que formal o legalmente está encargada de llevar a cabo funciones de comandante militar, de

49 VOLKER, Nerlich, "Superior Responsibility under Article 28 ICC Statute", Journal of International Criminal Justice, Vol. 5, Issue 3, (2007), pp. 665-682, p. 669.

${ }^{50}$ Sentencia de la Sala de Apelación, IT-97-25, The Prosecutor v. Krnojelac, Tribunal Penal Internacional para la ex Yugoslavia, 17 de septiembre de 2003, párrs. 170-172; Sentencia de Sala de Apelación, IT-95-15, The Prosecutor v. Blaskic, Tribunal Penal Internacional para la ex Yugoslavia, 29 de julio de 2004, párr. 77; Sentencia de la Sala de Apelación, IT-95-14/2, The Prosecutor v. Kordic \& Cerkez, Tribunal Penal Internacional para la ex Yugoslavia, 17 de diciembre de 2004, párr. 832; Sentencia de la Sala de Apelación, IT-01-47, The Prosecutor v. Hadzihasanovic, Tribunal Penal Internacional para la Ex Yugoslavia, 22 de abril de 2008, párrs. 38-42; Sentencia Sala de Primera Instancia, IT-96-21, The prosecutor v. Mucic et al (Celebici case), Tribunal Penal Internacional para la Ex Yugoslavia, 20 de febrero de 2001, párr. 400; Sentencia Sala de Primera Instancia, IT-01-48, The Prosecutor v. Halilovic, Tribunal Penal Internacional para la Ex Yugoslavia, 16 de noviembre de 2005, párrs. 75-78.

${ }^{51}$ CPI, sentencia de primera instancia en el caso Bemba, párr. 697. Vid. también, Decisión de confirmación de cargos, ICC-01/05-01/08-424, The Prosecutor v. Jean-Pierre Bemba Gombo, Sala de Cuestiones Preliminares II, Corte Penal Internacional, 3 de julio de 2009, párr. 407.

${ }^{52}$ Sentencia de la Sala de Apelación, IT-03-68, The Prosecutor v. Oric, Tribunal Penal Internacional para la ex Yugoslavia, 3 de julio de 2008, párr. 21. Vid también Blagojevic, párrs. 280, 282; Sentencia de Primera Instancia, ICTR-99-52-T, The Prosecutor v. Nahimana, Tribunal Penal Internacional para Ruanda, 3 de diciembre de 2003, párrs. 485, 486. 
OLASOLO, Héctor; CANOSA, Jannluck. "La Responsabilidad del Superior en el Acuerdo de Paz en Colombia a la luz del Derecho Internacional".

acuerdo con la legislación, los procedimientos y la práctica del Estado de que se trate (lo que tradicionalmente se ha designado con la expresión "superior militar de jure"). ${ }^{53}$ Esta condición no sólo es aplicable al comandante inmediato de quien es penalmente responsable por un crimen internacional, sino a todos los superiores militares con independencia del nivel en que se encuentren. ${ }^{54}$ Además, según el caso Bemba, la condición de "jefe militar" es también predicable a quienes, según sus propias regulaciones, ostenten la condición de superiores militares de los grupos armados organizados no gubernamentales. ${ }^{55}$

Junto a los superiores militares de jure, el art. 28 (a) ECPI se refiere a quienes, sin estar formal o legalmente reconocidos como superiores militares, y sin que tengan por qué dedicarse exclusivamente a funciones militares, actúan efectivamente como tales. ${ }^{56} \mathrm{La}$ capacidad para emitir órdenes, hacer seguimiento sobre su grado de cumplimiento y exigir su ejecución son indicios que reflejan esta situación de facto. ${ }^{57}$

La existencia de una relación superior-subordinado exige en todo caso que los superiores militares cuenten con un "mando y control efectivo" (de jure) o "autoridad y control efectivo" (de facto) sobre los subordinados que son responsables por los crímenes internacionales de que se trate. ${ }^{58}$ Según el caso Bemba, la expresión "mando" y "autoridad" son análogas porque solo denotan la diferente naturaleza, modalidad y forma en la que los superiores militares de jure y de facto ejercen el control efectivo sobre sus subordinados. ${ }^{59}$ Esto significa que el grado de "control efectivo" requerido para ambos tipos de superiores militares es el mismo. ${ }^{60}$

El art. 28 (b) ECPI, así como la jurisprudencia del TIPY, el TIPR y la CESL, ${ }^{61}$ establecen que la RespSup se extiende también a quienes se encuentren de jure o de facto en la

\footnotetext{
${ }^{53}$ Sentencia de Primera Instancia, ICC-01/05-01/08-3343, The Prosecutor v. Jean-Pierre Bemba Gombo, Sala de Primera Instancia III, Corte Penal Internacional, 21 de marzo de 2016, párr. 176.

${ }^{54}$ Sentencia de Primera Instancia, ICC-01/05-01/08-3343, The Prosecutor v. Jean-Pierre Bemba Gombo, Sala de Primera Instancia III, Corte Penal Internacional, 21 de marzo de 2016, párr. 179.

${ }^{55}$ Sentencia de Primera Instancia, ICC-01/05-01/08-3343, The Prosecutor v. Jean-Pierre Bemba Gombo, Sala de Primera Instancia III, Corte Penal Internacional, 21 de marzo de 2016, párr. 176.

${ }^{56}$ Sentencia de Primera Instancia, ICC-01/05-01/08-3343, The Prosecutor v. Jean-Pierre Bemba Gombo, Sala de Primera Instancia III, Corte Penal Internacional, 21 de marzo de 2016, párr. 177.

${ }^{57}$ TIPR, Prosecutor vs. Serushago, caso ICTR-98-39, sentencia del 5 de mayo de 1999, párr. 29.

${ }^{58}$ Sentencia de Primera Instancia, ICC-01/05-01/08-3343, The Prosecutor v. Jean-Pierre Bemba Gombo, Sala de Primera Instancia III, Corte Penal Internacional, 21 de marzo de 2016, párr. 184.

${ }^{59}$ Sentencia de Primera Instancia, ICC-01/05-01/08-3343, The Prosecutor v. Jean-Pierre Bemba Gombo, Sala de Primera Instancia III, Corte Penal Internacional, 21 de marzo de 2016, párr. 181. Vid. tampion, Decisión de confirmación de cargos, ICC-01/05-01/08-424, The Prosecutor v. Jean-Pierre Bemba Gombo, Sala de Cuestiones Preliminares II, Corte Penal Internacional, 3 de julio de 2009, párrs. 413-416.

${ }^{60}$ Sentencia de Primera Instancia, ICC-01/05-01/08-3343, The Prosecutor v. Jean-Pierre Bemba Gombo, Sala de Primera Instancia III, Corte Penal Internacional, 21 de marzo de 2016, párr. 181. Vid. tampion, Decisión de confirmación de cargos, ICC-01/05-01/08-424, The Prosecutor v. Jean-Pierre Bemba Gombo, Sala de Cuestiones Preliminares II, Corte Penal Internacional, 3 de julio de 2009, 413-416.

${ }^{61}$ TPIR, sentencia de primera instancia en el caso Akayesu, párr. 702); Sentencia de Primera Instancia, ICTR95-1-T, The Prosecutor v. Kayishema, Tribunal Penal Internacional para Ruanda, 21 de mayo de 1999, párr. 703); Sentencia Sala de Primera Instancia, IT-96-21, The prosecutor v. Mucic et al (Celebici case), Tribunal Penal Internacional para la Ex Yugoslavia, 20 de febrero de 2001, párr. 707.
} 
Polít. crim. Vol. 13, № 25 (Julio 2018) Art. 12, pp. 444-500.

[http://www.politicacriminal.cl/Vol_13/n_25/Vol13N25A12.pdf]

posición de superiores civiles o no militares. ${ }^{62}$ En ambos casos, se exige que el superior de que se trate tenga "autoridad y control efectivo" sobre los subordinados que son responsables de crímenes internacionales. La ausencia de toda referencia a la expresión "mando" denota el reconocimiento de que un superior civil no cuenta con las mismas herramientas que un superior militar de jure para controlar a sus subordinados (en particular, una cadena de mando sometida al principio de obediencia y un sistema disciplinario para sancionar la desobediencia). ${ }^{63}$ En consecuencia, la estructura jerárquica de las organizaciones a través de las cuales operan los superiores civiles se entiende que no será similar a aquella de las organizaciones militares. ${ }^{64}$

En todo caso, ya sea que se trate de superiores militares o civiles, de jure o de facto, los párrafos (a) y (b) del art. 28 ECPI, y los arts. 7(3) ETIPY, 6(3) ETIPR y 6(3) ECESL, requieren el "control efectivo" de los subordinados que sean responsables de los crímenes internacionales. En cuanto a la definición de este concepto, la CPI ha subrayado en el caso Bemba que según el art. 28 (a) ECPI el "control efectivo" se refiere a la capacidad material de prevenir o reprimir la comisión de crímenes internacionales por los subordinados, o, en su caso, de enviar la cuestión a las autoridades competentes. ${ }^{65}$ Por su parte, el TIPY, el TIPR y la CESL han definido el control efectivo como la capacidad material de (i) prevenir la comisión de delitos por parte de los subordinados (lo que se deriva del control operativo sobre los mismos como consecuencia de la capacidad de emitir órdenes y hacer que se ejecuten); o (ii) castigarlos (lo que incluiría la facultad de iniciar una investigación, suspender a los sospechosos de sus funciones oficiales durante la misma, y, eventualmente, imponer sanciones). ${ }^{66}$ Conforme a ambas definiciones, el hecho de que existan autoridades

\footnotetext{
${ }^{62}$ No es pacífico, sin embargo, en la doctrina que la extensión de la RespSup a los superiores civiles haya adquirido naturaleza consuetudinaria. Así, si bien Henckaerts \& Doswald-Beck afirman su carácter consuetudinario, otros autores, como Ronen, rechazan el mismo sobre la base de los pocos casos en los que tanto a nivel nacional como internacional se ha condenado a superiores civiles bajo esta forma de responsabilidad. Vid. HENCKAERTS, El derecho internacional, cit. nota ${ }^{\circ} 24$, párr. 153sc. Vid. también RONEN, Yael, "Superior Responsibility of Civilians for International Crimes Committed in Civilian Settings [article]", Vanderbilt Journal Of Transnational Law, Vol. 43, Issue 2, pp. 313-356, (2010).

${ }^{63}$ KISS, Alejandro, "Command Responsibility under Article 28 of Rome Statute", en STAHN, Carsten (Ed.), The Law and Practice of the International Criminal Court, Oxford: Oxford University Press, 2014, pp. 608648, p. 612.

${ }^{64}$ Vid. Sentencia de Primera Instancia, ICTR-95-1-T, The Prosecutor v. Kayishema, Tribunal Penal Internacional para Ruanda, 21 de mayo de 1999, párr. 217, en relación con un prefecto; Sentencia de Primera Instancia, ICTR-97-23, The Prosecutor v. Kambanda, Tribunal Penal Internacional para Ruanda, 4 de septiembre de 1998, párr. 39, en relación con un primer ministro; Sentencia de Primera Instancia, ICTR-9613-A, The Prosecutor v. Musema, Tribunal Penal Internacional para Ruanda, 27 de enero de 2000, párr. 868, en relación con el director de una fábrica de té; Sentencia de Primera Instancia, ICTR-99-52-T, The Prosecutor v. Nahimana, Tribunal Penal Internacional para Ruanda, 3 de diciembre de 2003, párr. 970, en relación con la dirección de una estación de radio.

${ }^{65}$ Sentencia de Primera Instancia, ICC-01/05-01/08-3343, The Prosecutor v. Jean-Pierre Bemba Gombo, Sala de Primera Instancia III, Corte Penal Internacional, 21 de marzo de 2016, párr. 183, Decisión de confirmación de cargos, ICC-01/05-01/08-424, The Prosecutor v. Jean-Pierre Bemba Gombo, Sala de Cuestiones Preliminares II, Corte Penal Internacional, 3 de julio de 2009.

${ }^{66}$ Sentencia de la Sala de Apelación, IT-96-21, The prosecutor v. Mucic et al (Celebici case), Tribunal Penal Internacional para la Ex Yugoslavia, 8 de abril de 2003, párr. 198; Sentencia de Sala de Apelación, IT-95-15, The Prosecutor v. Blaskic, Tribunal Penal Internacional para la ex Yugoslavia, 29 de julio de 2004, párrs. 67, 69; Sentencia de Primera Instancia, ICTR-97-20, The Prosecutor v. Semanza, Tribunal Penal Internacional
} 
OLASOLO, Héctor; CANOSA, Jannluck. "La Responsabilidad del Superior en el Acuerdo de Paz en Colombia a la luz del Derecho Internacional".

intermedias es irrelevante, con tal de que el superior conserve la capacidad material requerida. ${ }^{67}$ Además, el grado de control exigido para afirmar la existencia de una relación superior-subordinado es similar para superiores militares y civiles, ya sean de jure o de facto.

El TPIY y el TIPR han sostenido la posibilidad de afirmar la existencia de un control efectivo incluso cuando el superior sólo cuenta con un control parcial operativo (su competencia se limita a adoptar ciertas medidas dirigidas a prevenir los crímenes) o disciplinario (su competencia se limita a remitir la cuestión a la autoridad competente). ${ }^{68}$ Sin embargo, la aceptación de un estándar de control parcial plantea la cuestión relativa a si cualquier persona que tenga, por ejemplo, la capacidad material de poner en conocimiento de la autoridad competente la comisión de un crimen internacional puede ser considerada como superior. La CPI ha respondido a esta pregunta en el caso Bemba de manera circular porque se ha limitado a afirmar que la mera influencia sobre los responsables de un crimen internacional no es suficiente para que se predique la existencia de control efectivo sobre los mismos, sino que debe existir, cuando menos, la capacidad material para remitir el asunto a la autoridad competente. ${ }^{69}$ Ante esta situación, conviene señalar que el establecimiento de un umbral tan poco exigente para afirmar la existencia de control efectivo hace realmente difícil distinguir entre los casos en que es aplicable la RespSup porque existe el mismo, y los supuestos en que no es aplicable porque solamente existe una mera capacidad de influencia en los responsables de crímenes internacionales. ${ }^{70}$

para Ruanda, 15 de mayo de 2003; Sentencia de Primera Instancia, ICTR-96-19, The Prosecutor v. Ntakirutimana, Tribunal Penal Internacional para Ruanda, 21 de febrero de 2003, párr. 819.

${ }^{67}$ Sentencia de Primera Instancia, ICC-01/05-01/08-3343, The Prosecutor v. Jean-Pierre Bemba Gombo, Sala de Primera Instancia III, Corte Penal Internacional, 21 de marzo de 2016, párr.184, Sentencia de la Sala de Apelación, IT-03-68, The Prosecutor v. Oric, Tribunal Penal Internacional para la ex Yugoslavia, 3 de julio de 2008, para. 20; Sentencia de Primera Instancia, IT-03-68, The Prosecutor v. Oric, Tribunal Penal Internacional para la ex-Yugoslavia, 30 de junio de 2006, para. 311; Sentencia de Primera Instancia, SCSL2004-16-A, The Prosecutor v. Brima et al, Corte Especial para Sierra Leona, 22 de febrero de 2008, parr. 786; Sentencia Sala de Primera Instancia, IT-01-48, The Prosecutor v. Halilovic, Tribunal Penal Internacional para la ex-Yugoslavia, 16 de noviembre de 2005, paras 62 to 63; Sentencia de Primera Instancia, ICTY-01-42-T, The Prosecutor v. Strugar, Tribunal Penal Internacional para la ex Yugoslavia, 31 de enero de 2005, parr. 363 - 366; Sentencia de Primera Instancia, IT-98-34, The Prosecutor v. Naletilić and Martinović, Tribunal Penal Internacional para la ex-Yugoslavia, 31 de marzo de 2003, párr, 69; Sentencia de Primera Instancia, IT-97-21, The Prosecutor v. Krnojelac, Tribunal Penal Internacional para ex-Yugoslavia, 15 de marzo de 2002, párr. 93; Sentencia de Primera Instancia, IT-95-15, The Prosecutor v. Blaskic, Tribunal Penal Internacional para la ex Yugoslavia, 3 de marzo de 2000, parr 296 y 303; Sentencia de Primera Instancia, IT-95-14/1, The Prosecutor v. Aleksovski, Tribunal Penal Internacional para ex-Yugoslavia, 25 de junio de 1999, párr. 106.

${ }^{68}$ Sentencia de la Sala de Apelación, IT-96-21, The prosecutor v. Mucic et al (Celebici case), Tribunal Penal Internacional para la Ex Yugoslavia, 8 de abril de 2003, párrs. 190 a 198, 256, 266; Sentencia de la Sala de Apelación, ICTR-95-1A, The Prosecutor v. Bagilishema, Tribunal Penal Internacional para Ruanda, 3 de julio de 2002, párr. 51

${ }^{69}$ Decisión de confirmación de cargos, ICC-01/05-01/08-424, The Prosecutor v. Jean-Pierre Bemba Gombo, Sala de Cuestiones Preliminares II, Corte Penal Internacional, 3 de julio de 2009, párr. 425. Vid En nuestra opinión, la mera posibilidad de poner en conocimiento de la autoridad competente la comisión de un crimen internacional, que posee en términos generales cualquier ciudadano, no puede equiparse a control efectivo, a menos que, en virtud de la capacidad material que detenta un superior, dicha remisión significara un ejercicio de los poderes disciplinarios, o bien un impulso procesal relevante para la investigación. De ahí que se deba realizar un análisis caso por caso.

${ }^{70}$ OLASOLO, Tratado de Autoría, cit. nota n ${ }^{\circ}$ 32, p. 785. 
De la definición del requisito del control efectivo como capacidad material se derivan algunas consecuencias, como el hecho de que el control efectivo no tiene que ser exclusivo, sino que puede ser compartido con otros superiores, de ahí que múltiples superiores puedan ser penalmente responsables por los crímenes internacionales cometidos por sus subordinados, ${ }^{71}$ e inclusive, dicha responsabilidad penal puede extenderse a los demás miembros de la cadena de mando, hasta llegar al Jefe de Estado y a su Ministro de Defensa, o al jefe del grupo armado organizado de que se trate. ${ }^{72}$ Así mismo, la proximidad del superior a la escena del crimen no es un requisito jurídico para afirmar la existencia de control efectivo, de manera que serán las circunstancias del caso concreto las que determinen si el superior, a pesar de su posible lejanía con respecto a los subordinados responsables, detenta un control efectivo sobre los mismos. ${ }^{73}$

Al no ser el nombramiento conforme a la normatividad del Estado o las regulaciones internas del grupo armado de que se trate, ni necesario, ni suficiente, para la existencia de control efectivo (la capacidad material que se requiere es de naturaleza fáctica y no jurídica, ${ }^{74}$ por lo que el nombramiento oficial es a lo sumo un mero indicio ${ }^{75}$ ), es necesario probar el control efectivo caso por caso. Para ello, la CPI ha señalado en el caso Bemba lo siguientes factores como constitutivos de indicios de control efectivo: “(i) La posición oficial como comandante dentro de una estructura militar, (ii) el poder para dar órdenes, (iii) la capacidad para asegurar el cumplimiento de las ordenes, (iv) la capacidad para hacer cambios en la estructura, (v) el poder para promover, remover o disciplinar a cualquier miembro de las fuerzas o para iniciar investigaciones, (vi) la autoridad para enviar fuerzas

\footnotetext{
${ }^{71}$ Sentencia de Primera Instancia, ICC-01/05-01/08-3343, The Prosecutor v. Jean-Pierre Bemba Gombo, Sala de Primera Instancia III, Corte Penal Internacional, 21 de marzo de 2016, párr. 185. SCSL; Taylor Trial Judgment, para. 6984

${ }^{72}$ Sentencia de Primera Instancia, ICC-01/05-01/08-3343, The Prosecutor v. Jean-Pierre Bemba Gombo, Sala de Primera Instancia III, Corte Penal Internacional, 21 de marzo de 2016, párr. 179; Sentencia de la Sala de Apelación, IT-03-68, The Prosecutor v. Oric, Tribunal Penal Internacional para la ex Yugoslavia, 3 de julio de 2008, párr. 20.

${ }^{73}$ Sentencia de la Sala de Apelación, IT-03-68, The Prosecutor v. Oric, Tribunal Penal Internacional para la ex Yugoslavia, 3 de julio de 2008, párr. 20. Sobre el test del control efectivo, vid. también: Sentencia de la Sala de Apelación, IT-96-21, The prosecutor v. Mucic et al (Celebici case), Tribunal Penal Internacional para la Ex Yugoslavia, 8 de abril de 2003, párrs. 197, 256; Sentencia de Sala de Apelación, IT-95-15, The Prosecutor v. Blaskic, Tribunal Penal Internacional para la ex Yugoslavia, 29 de julio de 2004, párr. 67; Sentencia Sala de Primera Instancia, IT-01-48, The Prosecutor v. Halilovic, Tribunal Penal Internacional para la Ex Yugoslavia, 16 de noviembre de 2005, párr. 58; Sentencia sala de primera instancia, IT-01-47, The prosecutor v. Hadzihasanovic \& Kubura, Tribunal Penal Internacional para la Ex Yugoslavia, 15 de marzo de 2006, párr. 76; Sentencia de Primera Instancia, ICTR-97-20, The Prosecutor v. Semanza, Tribunal Penal Internacional para Ruanda, 15 de mayo de 2003, párr. 402; Sentencia de Primera Instancia, ICTR-99-46-T, The Prosecutor v. Ntagerura, Tribunal Internacional para Ruanda, 25 de febrero de 2004, párr. 628.

${ }^{74}$ Sentencia de Primera Instancia, ICC-01/05-01/08-3343, The Prosecutor v. Jean-Pierre Bemba Gombo, Sala de Primera Instancia III, Corte Penal Internacional, 21 de marzo de 2016, párr. 189.

${ }^{75}$ Sentencia de la Sala de Apelación, IT-03-68, The Prosecutor v. Oric, Tribunal Penal Internacional para la ex Yugoslavia, 3 de julio de 2008, párrs. 90, 91, 92; Sentencia de la Sala de Apelación, IT-01-47, The Prosecutor v. Hadzihasanovic, Tribunal Penal Internacional para la Ex Yugoslavia, 22 de abril de 2008, párr. 21; Sentencia de la Sala de Apelación, IT-96-21, The prosecutor v. Mucic et al (Celebici case), Tribunal Penal Internacional para la Ex Yugoslavia, 8 de abril de 2003, párr. 266; Sentencia de la Sala de Apelación, IT-95$14 / 2$, The Prosecutor v. Kordic \& Cerkez, Tribunal Penal Internacional para la ex Yugoslavia, 17 de diciembre de 2004, párrs. 842, 849.
} 
OLASOLO, Héctor; CANOSA, Jannluck. "La Responsabilidad del Superior en el Acuerdo de Paz en Colombia a la luz del Derecho Internacional".

al lugar de las hostilidades y para removerlas, (vii) el acceso directo al equipo de la milicia, así como a sus medios de comunicación, (viii) el control sobre las finanzas, y (ix) la capacidad de representar externamente al grupo". ${ }^{76}$

El TIPY ha afirmado que existen además otros factores constitutivos de indicios de control efectivo como la conducción de operaciones de combate que involucren a las fuerzas que son responsables por los crímenes internacionales, o la participación en negociaciones que afecten a dichas fuerzas. ${ }^{77}$ Así mismo, en relación con la facultad de emitir órdenes, el TPIY ha subrayado que la misma "[...] no significa automáticamente establecer que un superior tuvo control efectivo sobre sus subordinados, pero es uno de los indicadores a ser tenidos en cuenta cuando se establece el control efectivo". ${ }^{78}$

Además de la "autoridad y control efectivo", el art. 28(b) ECPI exige también en relación con los superiores civiles que los crímenes internacionales por los que los subordinados son responsables guarden relación con las actividades bajo la "responsabilidad y control efectivo" del superior. ${ }^{79}$ Si bien esta disposición no ha sido aún interpretada por la CPI, ni se recoge tampoco en los estatutos y jurisprudencia del TIPY, el TIPR y la CESL, la doctrina ha ofrecido algunos criterios al respecto. Así, Karsten cree que la distinción entre superiores militares y civiles tiene que ver con la naturaleza de la unidad o entidad en la que el superior ejerce el control efectivo, de modo que se entiende que un sujeto es superior militar si se observa en dicha unidad la lógica y el propósito de actuar como parte en el conflicto armado. Por, el contrario, el superior será civil cuando la entidad que controla no pretenda participar en el conflicto. Esto tiene para Karsten una relación directa con la naturaleza del control que cada tipo de superior ejerce sobre sus subordinados. ${ }^{80}$ Por su parte, para Werle ${ }^{81}$ y Ambos, ${ }^{82}$ la cláusula final del art. 28 (b) ECPI significa que la aplicación de la RespSup a los superiores civiles se limita al control efectivo que puedan

\footnotetext{
${ }^{76}$ Decisión de confirmación de cargos, ICC-01/05-01/08-424, The Prosecutor v. Jean-Pierre Bemba Gombo, Sala de Cuestiones Preliminares II, Corte Penal Internacional, 3 de julio de 2009, párr. 188.

77 Sentencia Sala de Primera Instancia, IT-96-21, The prosecutor v. Mucic et al (Celebici case), Tribunal Penal Internacional para la Ex Yugoslavia, 20 de febrero de 2001, párr. 767; Sentencia de la Sala de Apelación, IT-95-14/2, The Prosecutor v. Kordic \& Cerkez, Tribunal Penal Internacional para la ex Yugoslavia, 17 de diciembre de 2004, párr. 421; Sentencia de Primera Instancia, ICTY-01-42-T, The Prosecutor v. Strugar, Tribunal Penal Internacional para la ex Yugoslavia, 31 de enero de 2005, párrs. 404413; Sentencia sala de primera instancia, IT-01-47, The prosecutor v. Hadzihasanovic \& Kubura, Tribunal Penal Internacional para la Ex Yugoslavia, 15 de marzo de 2006, párr. 83. El hecho de que la única medida al alcance del superior para prevenir la comisión del delito sea el uso de la fuerza no impide afirmar el control efectivo. Vid. Sentencia sala de primera instancia, IT-01-47, The prosecutor v. Hadzihasanovic \& Kubura, Tribunal Penal Internacional para la Ex Yugoslavia, 15 de marzo de 2006, párrs. 85-88. En los casos de acción conjunta durante el combate de diferentes unidades, la cooperación entre las diferentes unidades no es per se suficiente para concluir que el superior de cada unidad ejerce control efectivo sobre todas las fuerzas implicadas en el combate. Vid. Sentencia sala de primera instancia, IT-01-47, The prosecutor v. Hadzihasanovic \& Kubura, Tribunal Penal Internacional para la Ex Yugoslavia, 15 de marzo de 2006, párr. 84.

${ }^{78}$ Sentencia de la Sala de Apelación, ICTY-01-42-A, The Prosecutor v. Strugar, Tribunal Penal Internacional para ex Yugoslavia, 17 de julio de 2008, párrs. 253, 254.

${ }^{79}$ OLASOLO, Tratado de Autoría, cit. nota $\mathrm{n}^{\circ} 32$, p. 782.

${ }^{80}$ KARSTEN, Nora, "Distinguishing Military and Non-military Superiors: Reflections on the Bemba Case at the ICC", J Int Criminal Justice, Vol. 7(5) (2009), pp. 983-1004, p. 999.

${ }^{81}$ WERLE, Tratado de Derecho Penal Internacional, cit. nota n ${ }^{\circ} 47$, p. 319.

${ }^{82}$ AMBOS, "Superior", cit nota ${ }^{\circ} 17$, p. 847.
} 
Polít. crim. Vol. 13, № 25 (Julio 2018) Art. 12, pp. 444-500.

[http://www.politicacriminal.cl/Vol_13/n_25/Vol13N25A12.pdf]

tener sobre sus subordinados en los asuntos relacionados con las actividades bajo su responsabilidad, lo que no sería el caso, por ejemplo, con los crímenes internacionales cometidos fuera del ámbito laboral.

Para finalizar, es importante delimitar el ámbito temporal en el que es posible aplicar la RespSup por crímenes internacionales por los que los subordinados son penalmente responsables. El problema que se plantea es el relativo a si la RespSup es solo aplicable a los crímenes internacionales por los que los subordinados incurren en responsabilidad mientras se tiene la condición de superior, o si por el contrario es aplicable a todos los crímenes internacionales por los que los subordinados son responsables con independencia de cuando hayan incurrido en dicha responsabilidad.

Frente a esta disyuntiva, el TPIY ha afirmado en el caso Hadzihasanovic et al., que la aplicación de la RespSup requiere ostentar dicha posición en el momento en que los subordinados incurren en responsabilidad. ${ }^{83}$ Por su parte, la CPI ha adoptado una posición algo más amplia en el caso Bemba al afirmar que la posición de superior se debe detentar en el periodo relevante para la comisión de los crímenes, que comenzaría desde que los responsables se proponen su comisión. ${ }^{84}$

Ahora bien, esto no quiere decir que los superiores no puedan ser penalmente responsables a título de autor o partícipe conforme a otras formas de responsabilidad previstas en el art. 25(3) ECPI (o en los arts. 7 (1) ETPIY, 6(1) ETIPR y 6(1) ECESL) por los crímenes internacionales cometidos por sus nuevos subordinados antes de asumir frente a los mismos la posición de superior. ${ }^{85}$ Así, el TIPY en los casos Blaskic, ${ }^{86}$ Simic $^{87}$ y Blagogevic ${ }^{88}$ y el TIPR en el caso Ntagerura han subrayado que la falta de diligencia en sancionar dichos crímenes podría dar lugar a responsabilidad como partícipe a título de complicidad por asistencia y cooperación cuando dicha omisión tenga por efecto sustancial asegurar la impunidad de los responsables. ${ }^{89}$ Esta misma interpretación es también posible en el marco del art. 25(3) ECPI. ${ }^{90}$

Así mismo, la omisión en sancionar o remitir a las autoridades competentes los asuntos relativos a los crímenes cometidos previamente por sus nuevos subordinados, puede provocar un incremento del riesgo en la comisión de futuros crímenes, frente a los cuáles el nuevo superior podría ser también responsable como partícipe a título de complicidad por

\footnotetext{
${ }^{83}$ Sentencia sala de primera instancia, IT-01-47, The prosecutor v. Hadzihasanovic \& Kubura, Tribunal Penal Internacional para la Ex Yugoslavia, 15 de marzo de 2006, párr. 51.

${ }^{84}$ Decisión de confirmación de cargos, ICC-01/05-01/08-424, The Prosecutor v. Jean-Pierre Bemba Gombo, Sala de Cuestiones Preliminares II, Corte Penal Internacional, 3 de julio de 2009, párr. 419.

${ }^{85}$ OLASOLO, Tratado de Autoría, cit. nota n ${ }^{\circ} 32$, p. 775.

${ }^{86}$ Sentencia de Sala de Apelación, IT-95-15, The Prosecutor v. Blaskic, Tribunal Penal Internacional para la ex Yugoslavia, 29 de julio de 2004, párr. 48.

${ }^{87}$ Sentencia de la Sala de Apelación, IT-95-9, The Prosecutor v. Simic et al, Tribunal Penal Internacional para ex Yugoslavia, 28 de noviembre de 2006, párr. 85.

${ }^{88}$ Sentencia de la Sala de Apelación, IT-02-60, The Prosecutor v. Blagojevic \& Jokic, Tribunal Penal Internacional para ex Yugoslavia. 9 de mayo de 2007, párr. 127.

${ }^{89}$ Sentencia de Primera Instancia, ICTR-99-46-T, The Prosecutor v. Ntagerura, Tribunal Internacional para Ruanda, 25 de febrero de 2004, párr. 372.

${ }^{90}$ OLASOLO, Tratado de Autoría, cit. nota n ${ }^{\circ}$ 32, p. 776.
} 
OLASOLO, Héctor; CANOSA, Jannluck. "La Responsabilidad del Superior en el Acuerdo de Paz en Colombia a la luz del Derecho Internacional".

asistencia y colaboración. ${ }^{91}$ Este sería particularmente el caso si el nuevo superior no sólo deja de castigar, sino que además utiliza para sus nuevas operaciones militares fuerzas de combate que han cometido crímenes internacionales en el pasado. ${ }^{92}$ Esta situación, podría permitir así mismo la aplicación de la RespSup en caso de que se considerase que el nuevo superior ha incumplido la obligación de prevenir futuros crímenes internacionales por sus nuevos subordinados. ${ }^{93}$

2.3.2.La omisión de la obligación jurídica del superior de adoptar todas las medidas razonables y necesarias a su disposición para prevenir, reprimir o enviar a la autoridad competente los crímenes internacionales de sus subordinados

Una vez demostrada la relación superior-subordinado, incluyendo la capacidad material (total o parcial) del superior para prevenir, reprimir o enviar los crímenes internacionales de sus subordinados a las autoridades competentes, los arts. 28(a)(ii) y (b)(iii) ECPI, 7(3) ETPIY, 6(3) ETPIR, y 6(3) ECESL requieren que el superior no haya tomado todas aquellas medidas necesarias y razonables que se encuentran dentro de su capacidad material para cumplir con sus obligaciones de prevenir, reprimir y enviar los crímenes de sus subordinados a las autoridades competentes. ${ }^{94}$

El superior no está obligado a realizar lo imposible, y sólo puede ser considerado responsable por no tomar las medidas que están dentro de su capacidad material, ${ }^{95}$ con independencia de si tiene la "competencia jurídico-formal" para llevarlas a cabo. ${ }^{96} \mathrm{La}$ determinación de cuáles son las medidas al alcance del superior es una cuestión probatoria que tiene que ser valorada caso por caso. ${ }^{97}$ Ello requiere analizar el Derecho nacional

${ }^{91}$ OLASOLO, Tratado de Autoría, cit. nota n o 32, pp. 773-781.

92 Sentencia sala de primera instancia, IT-01-47, The prosecutor v. Hadzihasanovic \& Kubura, Tribunal Penal Internacional para la Ex Yugoslavia, 15 de marzo de 2006, párr. 89.

${ }^{93}$ Decisión de confirmación de cargos, ICC-01/05-01/08-424, The Prosecutor v. Jean-Pierre Bemba Gombo, Sala de Cuestiones Preliminares II, Corte Penal Internacional, 3 de julio de 2009, párrs. 425, 426

94 NYBONDAS, Maria, "Civilian Superior Responsibility in the Kordic Case", Netherlands International Law Review, Vol. 50, Issue 1, (2003), pp 59-82, p. 68; WILLIAMSON, Jamie, "Command Responsibility in the Case Law of the International Criminal Tribunal for Rwanda", Criminal Law Forum, Vol. 13, Issue 3, , (2002), pp. 365-384, p. 380.

95 Sentencia Sala de Primera Instancia, IT-96-21, The prosecutor v. Mucic et al (Celebici case), Tribunal Penal Internacional para la Ex Yugoslavia, 20 de febrero de 2001, párr. 395; Sentencia de Primera Instancia, ICTY-01-42-T, The Prosecutor v. Strugar, Tribunal Penal Internacional para la ex Yugoslavia, 31 de enero de 2005, párr. 73; Sentencia sala de primera instancia, IT-01-47, The prosecutor v. Hadzihasanovic \& Kubura, Tribunal Penal Internacional para la Ex Yugoslavia, 15 de marzo de 2006, párr. 122; Sentencia de Primera Instancia, ICTR-95-1-T, The Prosecutor v. Kayishema, Tribunal Penal Internacional para Ruanda, 21 de mayo de 1999, párr. 217.

${ }^{96}$ Sentencia de Primera Instancia, ICTR-99-54A, The Prosecutor v. Kamuhanda, Tribunal Penal Internacional para Ruanda, 22 de enero de 2004, párr. 601.

${ }^{97}$ Sentencia de Sala de Apelación, IT-95-15, The Prosecutor v. Blaskic, Tribunal Penal Internacional para la ex Yugoslavia, 29 de julio de 2004, párr. 72; Sentencia Sala de Primera Instancia, IT-96-21, The prosecutor v. Mucic et al (Celebici case), Tribunal Penal Internacional para la Ex Yugoslavia, 20 de febrero de 2001, párr. 394; Sentencia de Primera Instancia, ICTY-01-42-T, The Prosecutor v. Strugar, Tribunal Penal Internacional para la ex Yugoslavia, 31 de enero de 2005, párr. 73; Sentencia sala de primera instancia, IT-01-47, The prosecutor v. Hadzihasanovic \& Kubura, Tribunal Penal Internacional para la Ex Yugoslavia, 15 de marzo de 2006, párr. 124. 
Polít. crim. Vol. 13, No 25 (Julio 2018) Art. 12, pp. 444-500.

[http://www.politicacriminal.cl/Vol_13/n_25/Vol13N25A12.pdf]

porque en el mismo se regulan los deberes y facultades de los representantes civiles y militares del Estado. ${ }^{98}$

De todas las medidas que el superior tiene a su disposición, sólo está obligado a adoptar aquellas que sean necesarias (adecuadas para prevenir o reprimir el crimen) y razonables (proporcionales con el bien jurídico protegido o a las circunstancias existentes en el momento) para cumplir con sus obligaciones jurídicas. ${ }^{99}$ Según la CPI en el caso Bemba, esto debe determinarse a la luz de las circunstancias concretas de cada caso. ${ }^{100}$ El hecho de que, a pesar de que el superior adopte las medidas necesarias y razonables que le son exigidas, los subordinados cometan los crímenes o éstos queden impunes, es irrelevante y no genera ningún tipo de responsabilidad penal. ${ }^{101}$

Con respecto a la obligación de prevenir los crímenes internacionales que los subordinados se proponer cometer, la CPI ha identificado las siguientes medidas de prevención: (i) asegurarse de que los subordinados han sido entrenados en DIH; (ii) obtener informes sobre el cumplimiento de las acciones militares conforme al DIH; (iii) dictar órdenes para que la forma de actuar de las unidades se ajuste al DIH; (iv) emitir ordenes con la intención especifica de prevenir los crímenes de que se trate; (v) realizar discursos de rechazo de las conductas punibles; (vi) insistir ante autoridades superiores sobre la necesidad de tomar medidas inmediatas; (vii) posponer operaciones militares; (viii) suspender, excluir o remover a subordinados violentos; (ix) conducir operaciones militares de tal modo que se reduzca el riesgo de ciertos crímenes internacionales o se limiten las oportunidades para su comisión; y (x) adoptar medidas disciplinarias para prevenir la comisión de crímenes internacionales. $^{102}$

Por su parte, el TIPY ha afirmado la existencia de otras medidas de prevención tales como: (i) iniciar una investigación cuando hay información que indique que los subordinados pueden estar a punto de cometer crímenes internacionales; (ii) suspender a aquellos subordinados que presuntamente están planeando la comisión de este tipo de crímenes o tienen antecedentes penales violentos (o, al menos, excluirlos de las operaciones de

98 PILlOUD, Commentary on, cit. nota n o 21, párrs. 3543 et seq. Vid. también Sentencia de Sala de Apelación, IT-95-15, The Prosecutor v. Blaskic, Tribunal Penal Internacional para la ex Yugoslavia, 29 de julio de 2004, párr. 414, que se basó en las regulaciones sobre la aplicación del Derecho Internacional a las Fuerzas Armadas de la República Federal Socialista de Yugoslavia (RFSY) para establecer el deber del superior de informar a las autoridades competentes sobre los crímenes internacionales de sus subordinados. Así mismo, la sentencia de primera instancia en el caso Aleksovski ante el TIPY, párr. 91, 136, tomó en consideración el hecho de que el Derecho de Bosnia y Herzegovina impone un deber cívico sobre todos sus ciudadanos de informar a las autoridades judiciales sobre cualquier delito.

${ }^{99}$ OLASOLO, Tratado de Autoría, cit. nota n ${ }^{\circ} 32$, p. 789.

100 Sentencia de Primera Instancia, ICC-01/05-01/08-3343, The Prosecutor v. Jean-Pierre Bemba Gombo, Sala de Primera Instancia III, Corte Penal Internacional, 21 de marzo de 2016, párr. 197; Decisión de confirmación de cargos, ICC-01/05-01/08-424, The Prosecutor v. Jean-Pierre Bemba Gombo, Sala de Cuestiones Preliminares II, Corte Penal Internacional, 3 de julio de 2009, párr. 477.

${ }^{101}$ Sentencia de Primera Instancia, ICC-01/05-01/08-3343, The Prosecutor v. Jean-Pierre Bemba Gombo, Sala de Primera Instancia III, Corte Penal Internacional, 21 de marzo de 2016, párr. 200.

102 Sentencia de Primera Instancia, ICC-01/05-01/08-3343, The Prosecutor v. Jean-Pierre Bemba Gombo, Sala de Primera Instancia III, Corte Penal Internacional, 21 de marzo de 2016, párr. 204; Decisión de confirmación de cargos, ICC-01/05-01/08-424, The Prosecutor v. Jean-Pierre Bemba Gombo, Sala de Cuestiones Preliminares II, Corte Penal Internacional, 3 de julio de 2009, párr. 438. 
OLASOLO, Héctor; CANOSA, Jannluck. "La Responsabilidad del Superior en el Acuerdo de Paz en Colombia a la luz del Derecho Internacional".

combate, y limitar, en la mayor medida posible, su interacción con civiles y prisioneros de guerra enemigos); (iii) transmitir informes a las autoridades competentes advirtiendo sobre el riesgo de que podrían cometerse crímenes de guerra en la ejecución de ciertas operaciones militares, y proponer medidas para evitar dichos riesgos; y (iv) poner en conocimiento de las autoridades competentes las denuncias sobre crímenes de guerra presuntamente cometidos en el pasado por las unidades subordinadas. ${ }^{103}$

En cuanto a la obligación de reprimir los crímenes internacionales que los subordinados estén cometiendo, la CPI distingue entre las medidas adecuadas para: (i) poner fin, refrenar o contener la comisión de crímenes internacionales por los subordinados; y (ii) sancionar a estos últimos mediante la investigación y apertura de los correspondientes procesos disciplinarios y/o penales. ${ }^{104}$ En relación con estas últimas, el superior, ante la ausencia de la facultad para imponer una sanción, debe al menos (i) informar a sus propios superiores sobre la situación mediante la redacción de un informe; (ii) proponer una sanción al superior que tiene el poder disciplinario, o -en el caso de que detente el mismo ese poderejercerlo dentro de los límites de su competencia; y (iii) cuando sea necesario en virtud de la gravedad del caso, remitir el caso a la autoridad judicial competente con la mayor cantidad posible de elementos de prueba sobre los hechos. ${ }^{105}$

2.3.3. El conocimiento que el superior tenía o debiera haber tenido de los crímenes internacionales de sus subordinados.

El art. 28 ECPI distingue entre superiores militares y civiles a la hora de establecer el elemento subjetivo de la RespSup. Así, el apartado (a)(i) dispone que el superior militar será penalmente responsable por incumplir con sus obligaciones de prevenir, reprimir y no someter los crímenes internacionales de sus subordinados a las autoridades competentes cuando "[...] hubiere sabido o, en razón de las circunstancias del momento, hubiere debido saber [,,]" que sus subordinados los estaban cometiendo o se proponían hacerlo. Por su parte, el apartado (b)(i) prevé que el superior civil sólo será penalmente responsable por incumplir con las mencionadas obligaciones si "[...] hubiere tenido conocimiento o deliberadamente hubiere hecho caso omiso de información que indicase claramente que los subordinados estaban cometiendo esos crímenes o se proponían cometerlos".

\footnotetext{
${ }^{103}$ Sentencia de primera Instancia, IT-95-15, The Prosecutor v. Blaskic, Tribunal Penal Internacional para la ex Yugoslavia, 3 de marzo de 2000, párr. 285; Sentencia Sala de Primera Instancia, IT-01-48, The Prosecutor v. Halilovic, Tribunal Penal Internacional para la Ex Yugoslavia, 16 de noviembre de 2005, párr. 89; Sentencia de Primera Instancia, ICTY-01-42-T, The Prosecutor v. Strugar, Tribunal Penal Internacional para la ex Yugoslavia, 31 de enero de 2005, párr. 374.

${ }^{104}$ Sentencia de Primera Instancia, ICC-01/05-01/08-3343, The Prosecutor v. Jean-Pierre Bemba Gombo, Sala de Primera Instancia III, Corte Penal Internacional, 21 de marzo de 2016, párr. 207.

${ }^{105}$ PILLOUD, Commentary on, cit. nota n ${ }^{\circ}$ 21, párr. 3562. Vid. también, Decisión de confirmación de cargos, ICC-01/05-01/08-424, The Prosecutor v. Jean-Pierre Bemba Gombo, Sala de Cuestiones Preliminares II, Corte Penal Internacional, 3 de julio de 2009, párr. 443; Sentencia de Primera Instancia, ICTR-95-1-T, The Prosecutor v. Kayishema, Tribunal Penal Internacional para Ruanda, 21 de mayo de 1999, párr. 514; Sentencia sala de primera instancia, IT-01-47, The prosecutor v. Hadzihasanovic \& Kubura, Tribunal Penal Internacional para la Ex Yugoslavia, 15 de marzo de 2006, párr. 178; Sentencia de Primera Instancia, ICTY01-42-T, The Prosecutor v. Strugar, Tribunal Penal Internacional para la ex Yugoslavia, 31 de enero de 2005, párr. 376.
} 
Polít. crim. Vol. 13, No 25 (Julio 2018) Art. 12, pp. 444-500.

[http://www.politicacriminal.cl/Vol_13/n_25/Vol13N25A12.pdf]

Los apartados (a)(i) y (b)(i) del art. 28 ECPI, prevén dos elementos alternativos, uno de los cuales es en ambos casos el relativo al conocimiento actual de que los subordinados estaban cometiendo o iban a cometer los crímenes. ${ }^{106}$ La presencia de este conocimiento actual no se puede presumir. ${ }^{107}$ sino que es necesario probarlo mediante prueba directa - como el testimonio de quien informó personalmente al superior que sus fuerzas estaban involucradas en crímenes internacionales ${ }^{108}$ - o, a falta de prueba directa, mediante prueba circunstancial. ${ }^{109}$ Esta última solo se puede aceptar cuando el conocimiento directo del superior es la única conclusión razonable que se deriva de la misma. ${ }^{110}$

La CPI ha aceptado como prueba circunstancial en el caso Bemba los factores que según la jurisprudencia del TIPY, el TIPR y la CESL constituyen indicios del conocimiento del superior. ${ }^{111}$ Entre ellos cabe mencionar los siguientes: el número de hechos punibles cometidos por los subordinados, su alcance y desarrollo a gran escala, el periodo de tiempo durante el que los hechos punibles se desarrollaron, el tipo y número de unidades subordinadas involucradas en su ejecución, la forma de actuar en operaciones similares a aquellas en las que se cometieron los delitos, los medios de comunicación disponibles, la existencia de un sistema de información y seguimiento dentro de la organización, la naturaleza de la posición del superior y su ámbito de responsabilidad en la estructura jerárquica, y el lugar en el que se encontraba el superior cuando se produjeron los crímenes internacionales. ${ }^{12}$ Así mismo, la CPI ha subrayado que no se requiere que el superior

${ }^{106}$ Decisión de confirmación de cargos, ICC-01/05-01/08-424, The Prosecutor v. Jean-Pierre Bemba Gombo, Sala de Cuestiones Preliminares II, Corte Penal Internacional, 3 de julio de 2009, párrs. 429 y 430

${ }^{107}$ Sentencia de Primera Instancia, ICC-01/05-01/08-3343, The Prosecutor v. Jean-Pierre Bemba Gombo, Sala de Primera Instancia III, Corte Penal Internacional, 21 de marzo de 2016, párr. 191. Vid Sentencia de Primera Instancia, IT-04-83-7, The Prosecutor v. Delic, Tribunal Penal Internacional para la ex Yugoslavia, 15 de septiembre de 2008, párr. 64; Sentencia de Primera Instancia, IT-95-14/2, The Prosecutor v. Kordic \& Cerkez, Tribunal Penal Internacional para la ex Yugoslavia, 26 de febrero de 2001, párr. 427; Sentencia sala de primera instancia, IT-01-47, The prosecutor v. Hadzihasanovic \& Kubura, Tribunal Penal Internacional para la Ex Yugoslavia, 15 de marzo de 2006, párr. 94.

${ }^{108}$ Sentencia de Primera Instancia, ICC-01/05-01/08-3343, The Prosecutor v. Jean-Pierre Bemba Gombo, Sala de Primera Instancia III, Corte Penal Internacional, 21 de marzo de 2016, párr. 191.

${ }^{109}$ Sentencia de Primera Instancia, ICC-01/05-01/08-3343, The Prosecutor v. Jean-Pierre Bemba Gombo, Sala de Primera Instancia III, Corte Penal Internacional, 21 de marzo de 2016, párr. 191. Vid también Sentencia de Primera Instancia, IT-04-83-7, The Prosecutor v. Delic, Tribunal Penal Internacional para la ex Yugoslavia, 15 de septiembre de 2008, párr. 64; Sentencia de Primera Instancia, IT-95-14/2, The Prosecutor v. Kordic \& Cerkez, Tribunal Penal Internacional para la ex Yugoslavia, 26 de febrero de 2001, párr. 427; Sentencia de la Sala de Apelación, IT-01-47, The Prosecutor v. Hadzihasanovic, Tribunal Penal Internacional para la Ex Yugoslavia, 22 de abril de 2008, párr. 94.

110 Sentencia de Primera Instancia, ICC-01/05-01/08-3343, The Prosecutor v. Jean-Pierre Bemba Gombo, Sala de Primera Instancia III, Corte Penal Internacional, 21 de marzo de 2016, párr. 191.

${ }^{111}$ Sentencia de Primera Instancia, ICC-01/05-01/08-3343, The Prosecutor v. Jean-Pierre Bemba Gombo, Sala de Primera Instancia III, Corte Penal Internacional, 21 de marzo de 2016, párr. 193.

${ }^{112}$ Sentencia de Primera Instancia, ICC-01/05-01/08-3343, The Prosecutor v. Jean-Pierre Bemba Gombo, Sala de Primera Instancia III, Corte Penal Internacional, 21 de marzo de 2016, párr. 193; Decisión de confirmación de cargos, ICC-01/05-01/08-424, The Prosecutor v. Jean-Pierre Bemba Gombo, Sala de Cuestiones Preliminares II, Corte Penal Internacional, 3 de julio de 2009, párr. 431; Sentencia Sala de Primera Instancia, IT-96-21, The prosecutor v. Mucic et al (Celebici case), Tribunal Penal Internacional para la Ex Yugoslavia, 20 de febrero de 2001, párr. 386; Sentencia de Primera Instancia, IT-95-15, The Prosecutor v. Blaskic, Tribunal Penal Internacional para la ex Yugoslavia, 3 de marzo de 2000, párr. 307; Sentencia de Primera Instancia, ICTY-01-42-T, The Prosecutor v. Strugar, Tribunal Penal Internacional para la ex Yugoslavia, 31 de enero de 2005, párr. 368; Sentencia de la Sala de Apelación, IT-03-68, The Prosecutor v. Oric, Tribunal 
OLASOLO, Héctor; CANOSA, Jannluck. "La Responsabilidad del Superior en el Acuerdo de Paz en Colombia a la luz del Derecho Internacional".

conozca la identidad de los individuos que cometen los crímenes, o que esté al tanto de cada detalle de su comisión, porque esto se hace más difícil conforme se asciende en la cadena de mando. ${ }^{113}$

El segundo elemento alternativo de los apartados (a)(i) y (b)(i) del art. 28 ECPI es menos exigente que el conocimiento actual, y está conformado respectivamente por los estándares "hubiere debido saber" aplicable a los superiores militares, y "hubiere hecho caso omiso de información que indicase claramente" aplicable a los superiores civiles. Según la CPI en el caso Bemba, "el proceso de redacción de esta disposición revela que sus redactores optaron por un enfoque más estricto en relación con los superiores militares y sus asimilados en comparación con otros superiores previstos en el artículo 28(b) del Estatuto. Esto está justificado por la naturaleza y el tipo de responsabilidad asignada a esta categoría de superiores". 114

La interpretación del estándar "hubiere debido saber" es objeto de controversia en la doctrina. Para autores como Schabas, ${ }^{115}$ Bantekas $^{116}$ y Keith ${ }^{117}$ se trata de un estándar de imprudencia simple. Sin embargo, Van Sliedregt ${ }^{118}$ y Landrum $^{119}$ consideran que esta disposición recoge un estándar de imprudencia grave o temeridad. Como único punto en común se observa el rechazo a su construcción como un supuesto de responsabilidad objetiva. $^{120}$

La CPI ha señalado en el caso Bemba que la expresión "hubiere debido saber" introduce un estándar de imprudencia simple en relación con los superiores militares. ${ }^{121}$ En consecuencia, estos últimos incurren en responsabilidad penal si no se desempeñan con la diligencia esperada de un superior militar razonable actuando en similares circunstancias para: (i) obtener y valorar la información sobre el hecho de que sus subordinados se

Penal Internacional para la ex Yugoslavia, 3 de julio de 2008, párr. 319 Sentencia de Primera Instancia, ICTR-98-41, The Prosecutor v. Bagosora et al. (Military I), Tribunal Penal Internacional para Ruanda, 18 de diciembre de 2008, párr. 2014. En relación con el valor como prueba circunstancial del sistema de información y seguimiento dentro de las estructuras jerárquica dirigida por el superior, Sentencia de Primera Instancia, IT-01-47, The prosecutor v. Hadzihasanovic \& Kubura, Tribunal Penal Internacional para la Ex Yugoslavia, 15 de marzo de 2006, párr. 94.

${ }^{113}$ Decisión de confirmación de cargos, ICC-01/05-01/08-424, The Prosecutor v. Jean-Pierre Bemba Gombo, Sala de Cuestiones Preliminares II, Corte Penal Internacional, 3 de julio de 2009, párr. 434.

114 Decisión de confirmación de cargos, ICC-01/05-01/08-424, The Prosecutor v. Jean-Pierre Bemba Gombo, Sala de Cuestiones Preliminares II, Corte Penal Internacional, 3 de julio de 2009, párr. 433

115 SCHABAS, William, "General Principles of Criminal Law in the International Criminal Court Statute, Part III”, European Journal of Crime, Criminal Law and Criminal Justice, Vol. 6, Issue 4 (1988), pp. 84-112..

116 BANTEKAS, Illias, "The Contemporary Law of Superior Responsibility", American Journal of International Law, Vol. 93, No.3 (1999), pp. 573-595.

117 KEITH, Kirsten, "The Mens Rea of Superior Responsibility as Developed by ICTY Jurisprudence”, Leiden Journal of International Law, Vol. 14, Issue 3 (2001), pp. 617-634, p. 632.

${ }^{118}$ VAN SLIEDREGY, Elies, The Criminal Responsibility of Individuals for Violations of International Humanitarian Law, La Haya: TMC Asser Press, 2007, p. 54.

119 LANDRUM, Bruce, "The Yamashita War Crimes Trial: Command Responsibility Then and Now", Military Law Review, Vol. 149 (1995), pp. 293-301, p. 300.

120 JIA, Bing, "The Doctrine of Command Responsibility: Current Problems", Yearbook of International Humanitarian Law, Vol. 3 (2000), pp. 131-165, pp. 161 y 162.

${ }^{121}$ Decisión de confirmación de cargos, ICC-01/05-01/08-424, The Prosecutor v. Jean-Pierre Bemba Gombo, Sala de Cuestiones Preliminares II, Corte Penal Internacional, 3 de julio de 2009, párr. 433. 
Polít. crim. Vol. 13, № 25 (Julio 2018) Art. 12, pp. 444-500.

[http://www.politicacriminal.cl/Vol_13/n_25/Vol13N25A12.pdf]

proponen cometer crímenes internacionales o los están cometiendo; (imprudencia en tomar conocimiento de la situación que activa la obligación de intervención); (ii) valorar diligentemente las medidas a su disposición que son necesarias y razonables para prevenir, reprimir o, en su caso, enviar ante las autoridades competentes los crímenes internacionales cometidos por sus subordinados (imprudencia en la apreciación del alcance del poder de intervención); y (iii) aplicar las medidas a su alcance elegidas. ${ }^{122}$ Según la CPI en el caso Bemba, tanto los factores arriba mencionados en cuanto constitutivos de indicios del conocimiento actual del superior, como los acogidos por el TIPY y el TIPR como indicios de que el superior al menos "tenía razón para conocer", pueden ser utilizados para probar el estándar "hubiere debido saber". ${ }^{123}$

Con respecto al estándar "deliberadamente hubiere hecho caso omiso de información que indicase claramente", exigido por el art. 28(b)(1) ECPI en relación con los superiores civiles, la doctrina ha planteado también diversas interpretaciones. Por un lado, Schabas ${ }^{124}$ consideran que el mismo exige un "conocimiento" al que se llega por medio de la prueba circunstancial (constructive knowledge). Por otro lado, Werle entiende que nos encontramos más bien en el ámbito de la imprudencia grave propia de los sistemas romanogermánico $^{125}$. Si bien la CPI no ha abordado todavía esta cuestión, lo cierto es que la interpretación propuesta por Fenrick y Schabas eliminaría de hecho la alternativa entre los estándares de "conocimiento" y "deliberadamente hubiere hecho caso omiso de información que indicase claramente". En consecuencia, con el fin de dotar a este último estándar de un significado normativo propio, ${ }^{126}$ parece más adecuada la tesis de la imprudencia grave propuesta por Werle, o incluso su consideración como un supuesto de culpa consciente. ${ }^{127}$

A diferencia del art. 28 ECPI, los arts. 7(3) ETPIY, 6(3) ETPIR, y 6(3) ECESL establecen un mismo elemento subjetivo para la RespSup con independencia de su condición de militar o civil. Conforme al mismo, el superior sólo será penamente responsable si al incumplir sus obligaciones jurídicas de prevenir y castigar "conocía" o "tenía razones para saber" que sus subordinados habían cometido un crimen internacional o se proponían hacerlo. ${ }^{128}$ Se trata de nuevo de una formulación alternativa, cuya primera parte exige un estándar de conocimiento similar al que hemos analizado en relación con los apartados (a)(1) y (b)(1) del art. 28 ECPI. ${ }^{129}$

En cuanto al estándar "tenía razones para saber", el TIPY y el TIPR han rechazado su equiparación a un estándar de imprudencia simple similar al recogido en la expresión

122 OLASOLO, Tratado de Autoría, cit. nota n ${ }^{\circ} 32$, pp. 799, 800.

${ }^{123}$ Decisión de confirmación de cargos, ICC-01/05-01/08-424, The Prosecutor v. Jean-Pierre Bemba Gombo, Sala de Cuestiones Preliminares II, Corte Penal Internacional, 3 de julio de 2009, párr. 434.

124 SCHABAS, William, An Introduction to International Criminal Law 3ed, Cambridge: Cambridge University Press, 2007, p. 221.

${ }^{125}$ WERLE, Tratado de Derecho Penal Internacional, cit. nota n ${ }^{\circ} 47$, p. 321.

${ }^{126}$ AMBOS, "Superior", cit. nota ${ }^{\circ}$ 17, p. 852

${ }^{127}$ OLASOLO, Tratado de Autoría, cit. nota n ${ }^{\circ} 32$, p. 802.

128 TIPR 6(3), TPIY 7(3) y de la CESL 6(3)

${ }^{129}$ OLASOLO, Tratado de Autoría, cit. nota n ${ }^{\circ} 32$, p. 797 
OLASOLO, Héctor; CANOSA, Jannluck. "La Responsabilidad del Superior en el Acuerdo de Paz en Colombia a la luz del Derecho Internacional".

"hubiera debido saber" del art. 28 (a)(i) ECPI. ${ }^{130}$ Se trata, en todo caso, de un estándar más exigente porque no castiga la mera falta de diligencia del superior al cumplir con su deber de informarse sobre las actividades de sus subordinados. ${ }^{131}$ En consecuencia, se requiere que el superior haya tenido a su alcance información de carácter general que pudiera alertarlo de (i) los posibles crímenes internacionales que sus subordinados estuvieran cometiendo o se propusieran cometer; y (ii) la consiguiente necesidad de iniciar una investigación para clarificar esta situación. ${ }^{132}$

${ }^{130}$ La sentencia de primera instancia del TIPY en el caso Blaskic interpretó la la expresión "tenía razones para saber" como si se tratara de un estándar de imprudencia simple similar al recogido en la expresión "hubiera debido saber" del art. 28 (a)(i) ECPI. Las razones dadas en el párrafo 332 para justificar esta interpretación son las siguientes: "Si un comandante ha obrado con debida diligencia en el cumplimiento de sus deberes, pero carece sin embargo de conocimiento respecto de que los crímenes están por ser o fueron cometidos, esa falta de conocimiento no puede ser considerada en su contra. Sin embargo, teniendo en cuenta su posición particular de mando y las circunstancias imperantes en aquel momento, esa ignorancia no puede ser una defensa, cuando la ausencia de conocimiento es el resultado de la imprudencia en el cumplimiento de sus deberes: este comandante tenía razones para saber de conformidad con el Estatuto". Sin embargo, las Salas de Apelaciones del TIPY y el TIPR han rechazado sistemáticamente esta interpretación. Vid. Sentencia de la Sala de Apelación, ICTR-95-1A, The Prosecutor v. Bagilishema, Tribunal Penal Internacional para Ruanda, 3 de julio de 2002, párr. 35-42; Sentencia de la Sala de Apelación, IT-96-21, The prosecutor v. Mucic et al (Celebici case), Tribunal Penal Internacional para la Ex Yugoslavia, 8 de abril de 2003, párr. 241; Sentencia de la Sala de Apelación, IT-97-25, The Prosecutor v. Krnojelac, Tribunal Penal Internacional para la ex Yugoslavia, 17 de septiembre de 2003, párr. 15; Sentencia de Sala de Apelación, IT-95-15, The Prosecutor v. Blaskic, Tribunal Penal Internacional para la ex Yugoslavia, 29 de julio de 2004, párr. 62; Sentencia de la Sala de Apelación, IT-98-29, The Prosecutor v. Galic, Tribunal Penal Internacional para la ex Yugoslavia, 30 de noviembre de 2005, párr. 184; Sentencia Primera Instancia, IT-01-47, The prosecutor v. Hadzihasanovic \& Kubura, Tribunal Penal Internacional para la Ex Yugoslavia, 15 de marzo de 2006, párrs. 26-29; Sentencia de la Sala de Apelación, IT-03-68, The Prosecutor v. Oric, Tribunal Penal Internacional para la ex Yugoslavia, 3 de julio de 2008, párr. 5; Sentencia de Primera Instancia, ICTY-01-42-T, The Prosecutor v. Strugar, Tribunal Penal Internacional para la ex Yugoslavia, 31 de enero de 2005, párr. 297. Vid. también a este respecto, M.R. Lippman, "The Evolution and Scope of Command Responsibility" (2000) 13 Leiden Journal of International Law, p. 157; N. Keijzer y E. Van Sliedregt, "Commentary to Blaskic Judgment" en A. Klip y G. Sluiter, Annotated Leading Cases of International Criminal Tribunals (Vol. 4, Oxford, Hart Publishing, 2001), p. 656, 657; M.F. Tinta, "Commanders on Trial: The Blaskic Case and the Doctrine of Command Responsibility" (2000) 47 Netherlands International Law Review, pp. 293-322.

${ }^{131}$ Sentencia de la Sala de Apelación, IT-96-21, The prosecutor v. Mucic et al (Celebici case), Tribunal Penal Internacional para la Ex Yugoslavia, 8 de abril de 2003, párr. 226. Vid. también Sentencia de la Sala de Apelación, ICTR-95-1A, The Prosecutor v. Bagilishema, Tribunal Penal Internacional para Ruanda, 3 de julio de 2002, párr. 35, donde se subraya que "las referencias a la imprudencia en el contexto de la RespSup podrían conducir a una confusión de ideas".

132 Sentencia de la Sala de Apelación, ICTR-95-1A, The Prosecutor v. Bagilishema, Tribunal Penal Internacional para Ruanda, 3 de julio de 2002, párrs. 35-42; Sentencia de la Sala de Apelación, IT-96-21, The prosecutor v. Mucic et al (Celebici case), Tribunal Penal Internacional para la Ex Yugoslavia, 8 de abril de 2003, párr. 241; Sentencia de la Sala de Apelación, IT-97-25, The Prosecutor v. Krnojelac, Tribunal Penal Internacional para la ex Yugoslavia, 17 de septiembre de 2003, párr. 151; Sentencia de Sala de Apelación, IT95-15, The Prosecutor v. Blaskic, Tribunal Penal Internacional para la ex Yugoslavia, 29 de julio de 2004, párr. 62; Sentencia de la Sala de Apelación, IT-98-29, The Prosecutor v. Galic, Tribunal Penal Internacional para la ex Yugoslavia, 30 de noviembre de 2005, párr. 184; Sentencia sala de primera instancia, IT-01-47, The prosecutor v. Hadzihasanovic \& Kubura, Tribunal Penal Internacional para la Ex Yugoslavia, 15 de marzo de 2006, párrs. 26-29; Sentencia de la Sala de Apelación, IT-03-68, The Prosecutor v. Oric, Tribunal Penal Internacional para la ex Yugoslavia, 3 de julio de 2008, párr. 51; Sentencia de Primera Instancia, ICTY01-42-T, The Prosecutor v. Strugar, Tribunal Penal Internacional para la ex Yugoslavia, 31 de enero de 2005, párr. 297. Vid. también CARNERO, Enrique, "The Strugar Case before the International Criminal Tribunal 
Polít. crim. Vol. 13, № 25 (Julio 2018) Art. 12, pp. 444-500.

[http://www.politicacriminal.cl/Vol_13/n_25/Vol13N25A12.pdf]

Esto no significa, sin embargo, que la información al alcance de los superiores deba ser de tal naturaleza que por sí misma establezca que sus subordinados estén a punto de cometer los crímenes o los hayan cometido. ${ }^{133}$ Además, tampoco es necesario que la misma contenga detalles específicos sobre crímenes de que se trate. ${ }^{134}$

Ahora bien, dependiendo de las circunstancias del caso, el conocimiento del superior sobre los crímenes internacionales cometidos por sus subordinados en el pasado podría ser suficiente para alertarlo de que otros crímenes de naturaleza similar podrían ser llevados a cabo por el mismo "grupo identificable de subordinados" que opera en la misma área geográfica. ${ }^{135}$ Además, en relación con el deber de reprimir (castigar) en situaciones en las

for the Former Yugoslavia”, Journal of International Law of Peace and Armed Conflict, Vol. 2 (2005), pp. 139-145, pp. 140-142.

133 Sentencia de la Sala de Apelación, ICTR-95-1A, The Prosecutor v. Bagilishema, Tribunal Penal Internacional para Ruanda, 3 de julio de 2002, párr. 28; Sentencia de la Sala de Apelación, IT-96-21, The prosecutor v. Mucic et al (Celebici case), Tribunal Penal Internacional para la Ex Yugoslavia, 8 de abril de 2003, párr. 238; Sentencia de la Sala de Apelación, IT-97-25, The Prosecutor v. Krnojelac, Tribunal Penal Internacional para la ex Yugoslavia, 17 de septiembre de 2003, párrs. 154, 155; Sentencia de la Sala de Apelación, IT-98-29, The Prosecutor v. Galic, Tribunal Penal Internacional para la ex Yugoslavia, 30 de noviembre de 2005, párr. 184; Sentencia de la Sala de Apelación, ICTY-01-42-A, The Prosecutor v. Strugar, Tribunal Penal Internacional para ex Yugoslavia, 17 de julio de 2008, párr. 298; Sentencia de Primera Instancia, IT-95-14/2, The Prosecutor v. Kordic \& Cerkez, Tribunal Penal Internacional para la ex Yugoslavia, 26 de febrero de 2001, párrs. 436, 437; Sentencia sala de primera instancia, IT-01-47, The prosecutor v. Hadzihasanovic \& Kubura, Tribunal Penal Internacional para la Ex Yugoslavia, 15 de marzo de 2006, párr. 97

134 Sentencia de la Sala de Apelación, ICTR-95-1A, The Prosecutor v. Bagilishema, Tribunal Penal Internacional para Ruanda, 3 de julio de 2002, párr. 28; Sentencia de la Sala de Apelación, IT-96-21, The prosecutor v. Mucic et al (Celebici case), Tribunal Penal Internacional para la Ex Yugoslavia, 8 de abril de 2003, párr. 238; Sentencia de la Sala de Apelación, IT-97-25, The Prosecutor v. Krnojelac, Tribunal Penal Internacional para la ex Yugoslavia, 17 de septiembre de 2003, párrs. 154, 155; Sentencia de la Sala de Apelación, IT-98-29, The Prosecutor v. Galic, Tribunal Penal Internacional para la ex Yugoslavia, 30 de noviembre de 2005, párr. 184; Sentencia de la Sala de Apelación, ICTY-01-42-A, The Prosecutor v. Strugar, Tribunal Penal Internacional para ex Yugoslavia, 17 de julio de 2008, párr. 298; Sentencia de Primera Instancia, IT-95-14/2, The Prosecutor v. Kordic \& Cerkez, Tribunal Penal Internacional para la ex Yugoslavia, 26 de febrero de 2001, párrs. 436, 437; Sentencia sala de primera instancia, IT-01-47, The prosecutor v. Hadzihasanovic \& Kubura, Tribunal Penal Internacional para la Ex Yugoslavia, 15 de marzo de 2006, párr. 97. La información de naturaleza general que cumple con el estándar "tenía razones para saber" que los subordinados estaban por cometer crímenes internacionales, existe por ejemplo cuando: (i) un superior ha sido informado de que algunos soldados bajo su mando estaban bebiendo antes de ser enviados a una misión o se caracterizan por tener un temperamento violento o inestable (TIPY, sentencia de apelación en el caso Delalic et al., párr. 228); o (ii) un superior ha sido informado del bajo nivel de entrenamiento o los hábitos de algunos de sus subordinados (Sentencia de Primera Instancia, IT-95-14/2, The Prosecutor v. Kordic \& Cerkez, Tribunal Penal Internacional para la ex Yugoslavia, 26 de febrero de 2001, párr. 247). Así mismo, emitir órdenes para cumplir con el DIH no es per se suficiente para demostrar que un superior conocía o tenía razones para saber que sus subordinados iban a cometer delitos. Vid. a este respecto: Sentencia de la Sala de Apelación, IT-96-21, The prosecutor v. Mucic et al (Celebici case), Tribunal Penal Internacional para la Ex Yugoslavia, 8 de abril de 2003, párr. 238; Sentencia sala de primera instancia, IT-01-47, The prosecutor v. Hadzihasanovic \& Kubura, Tribunal Penal Internacional para la Ex Yugoslavia, 15 de marzo de 2006, párr. 100.

135 Sentencia de la Sala de Apelación, ICTY-01-42-A, The Prosecutor v. Strugar, Tribunal Penal Internacional para ex Yugoslavia, 17 de julio de 2008, párrs. 299-301; Sentencia de la Sala de Apelación, IT-97-25, The Prosecutor v. Krnojelac, Tribunal Penal Internacional para la ex Yugoslavia, 17 de septiembre de 2003, párr. 
OLASOLO, Héctor; CANOSA, Jannluck. "La Responsabilidad del Superior en el Acuerdo de Paz en Colombia a la luz del Derecho Internacional".

que se producen múltiples delitos de naturaleza similar, el conocimiento del superior de que sus subordinados han cometido un determinado tipo de crímenes internacionales es suficiente para alertarlo del hecho de que otros crímenes de similar naturaleza podrían haber sido cometidos previamente por dicho "grupo identificable de subordinados". ${ }^{136}$

\subsubsection{El nexo causal entre la omisión del superior y los delitos de sus subordinados.}

La diferencia más notoria entre el art. 28 ECPI por un lado, y los arts. 7(3) ETIPY, 6 (3) ETIPR y 6 (3) ECESL por otro, es la exigencia en el primero de un nexo causal entre la omisión del superior y los crímenes de sus subordinados. Este nexo causal, rechazado por la jurisprudencia del TIPY, el TIPY y la CESL, ${ }^{137}$ se recoge en la expresión "en razón de no haber ejercido un control apropiado sobre esas fuerzas [...]" contenida en el art. 28(a) y (b) ECPI.

El contenido literal de esta expresión, y la necesidad de proceder a una interpretación estricta de la misma conforme a lo exigido por el principio de legalidad previsto en el art. 22 (2) ECPI, ha llevado a la CPI a afirmar la exigencia de dicho nexo causal. ${ }^{138}$ Además, la propia CPI ha afirmado que la existencia de este nexo causal se justifica en el principio general del Derecho penal según el cual no puede haber responsabilidad penal por un crimen en ausencia de algún nexo personal con el mismo. ${ }^{139}$

La CPI ha definido el contenido de este nexo causal como "el incremento del riesgo" de que las fuerzas subordinadas al superior cometan los crímenes internacionales, como resultado del incumplimiento de las obligaciones jurídicas del superior. ${ }^{140}$ Esto no quiere

155; Sentencia de Primera Instancia, IT-01-47, The prosecutor v. Hadzihasanovic \& Kubura, Tribunal Penal Internacional para la Ex Yugoslavia, 15 de marzo de 2006, párrs. 115-117.

${ }^{136}$ Sentencia de Primera Instancia, IT-01-47, The prosecutor v. Hadzihasanovic \& Kubura, Tribunal Penal Internacional para la Ex Yugoslavia, 15 de marzo de 2006, párr. 185, Sentencia de la Sala de Apelación, IT97-25, The Prosecutor v. Krnojelac, Tribunal Penal Internacional para la ex Yugoslavia, 17 de septiembre de 2003, párrs. 156-169.

137 A pesar de que la sentencia de primera instancia del TIPY en el caso Delalic et al. exigió la existencia de un nexo causal entre la no omisión del deber de prevenir del superior y la comisión de los crímenes internacionales por los subordinados, la Sala de Apelaciones del TIPY ha rechazado esta interpretación en las sentencias de apelación en el caso Blaskic (párr. 77), Krnojelac (párrs. 170-172) y Hadzihasanovic et al. (párrs. 38-40). Esta misma solución ha sido adoptada en sistemas nacionales con tradiciones jurídicas tan diferentes, como Alemania y Estados Unidos. Con respecto a Alemania Vid. Ley de introducción del Código penal internacional VSyGB, Boletín Oficial de Leyes Federales de la República de Alemania (BGBI), 26 de junio de 2002, § 13(a) y (b). Con respecto a Estados Unidos, Vid. Sentencia en el caso Ford v. Garcia, No. 01-10357, Corte de Apelación de los Estados Unidos, Circuito Onceavo, 30 de abril de 2002, en especial, al rechazar el argumento de que la causa próxima es un elemento requerido por la doctrina de la responsabilidad de mando. En el mismo sentido, Sentencia en el caso Hilao v. Estate of Marcos, No. 95-15779, Corte de Apelación de los Estados Unidos, Circuito Noveno, 16 de junio de 1994.

${ }^{138}$ Sentencia de Primera Instancia, ICC-01/05-01/08-3343, The Prosecutor v. Jean-Pierre Bemba Gombo, Sala de Primera Instancia III, Corte Penal Internacional, 21 de marzo de 2016, párr. 213; Decisión de confirmación de cargos, ICC-01/05-01/08-424, The Prosecutor v. Jean-Pierre Bemba Gombo, Sala de Cuestiones Preliminares II, Corte Penal Internacional, 3 de julio de 2009, párrs. 422, 423.

${ }^{139}$ Sentencia de Primera Instancia, ICC-01/05-01/08-3343, The Prosecutor v. Jean-Pierre Bemba Gombo, Sala de Primera Instancia III, Corte Penal Internacional, 21 de marzo de 2016, párr. 213.

${ }^{140}$ Sentencia de Primera Instancia, ICC-01/05-01/08-3343, The Prosecutor v. Jean-Pierre Bemba Gombo, Sala de Primera Instancia III, Corte Penal Internacional, 21 de marzo de 2016, párr. 213; Decisión de confirmación 
Polít. crim. Vol. 13, № 25 (Julio 2018) Art. 12, pp. 444-500.

[http://www.politicacriminal.cl/Vol_13/n_25/Vol13N25A12.pdf]

decir, sin embargo, que el art. 28 ECPI requiera una causalidad but for propia del sistema del common law, ${ }^{141}$ o de equivalencia de las condiciones en el sistema romano-germánico, de acuerdo con la cual se requiere que la omisión jurídicamente reprochable no pueda ser eliminada mentalmente sin que desaparezca el resultado punible. ${ }^{142}$

Finalmente, es importante subrayar el debate existente en la doctrina sobre si este nexo de causalidad se puede predicar respecto del incumplimiento del superior con sus obligaciones de prevenir, reprimir y remitir a la autoridad competente los crímenes internacionales de sus subordinados; o si solo se puede predicar de la omisión del deber de prevenir, en la medida en que es el único que surge con anterioridad a la comisión de los crímenes. ${ }^{143}$

La SCP II de la CPI ha adoptado esta segunda posición al considerar "ilógico" que una violación de los deberes de reprimir y someter el asunto a las autoridades competentes pueda retroactivamente causar la comisión de los crímenes ya consumados. ${ }^{144}$ Otra cosa es que dicho incumplimiento pueda generar un incremento del riesgo de comisión de crímenes internacionales en el futuro. ${ }^{145}$

Sin embargo, esta posición tampoco es pacífica dentro de la CPI porque, si bien la Mayoría de la SPI III evitó pronunciarse sobre esta cuestión, ${ }^{146}$ la magistrada Sylvia Steiner, en su opinión separada a la sentencia de primera instancia, afirmo que dicho nexo de causalidad también debería extenderse al incumplimiento de estos otros deberes. ${ }^{147} \mathrm{Si}$ bien esta última posición nos resulta problemática al generar una especie de vínculo de causalidad automático de naturaleza normativa, ${ }^{148}$ lo cierto es que será necesario esperar a que la CPI ofrezca mayor claridad sobre esta cuestión en sus decisiones futuras.

de cargos, ICC-01/05-01/08-424, The Prosecutor v. Jean-Pierre Bemba Gombo, Sala de Cuestiones Preliminares II, Corte Penal Internacional, 3 de julio de 2009, párr. 426.

${ }^{141}$ Sentencia de Primera Instancia, ICC-01/05-01/08-3343, The Prosecutor v. Jean-Pierre Bemba Gombo, Sala de Primera Instancia III, Corte Penal Internacional, 21 de marzo de 2016, párr. 211; Decisión de confirmación de cargos, ICC-01/05-01/08-424, The Prosecutor v. Jean-Pierre Bemba Gombo, Sala de Cuestiones Preliminares II, Corte Penal Internacional, 3 de julio de 2009, párr. 425

142 OSPINA, Camila; CANOSA, Jannluck, "Situación en África Central, caso del Fiscal contra Jean Pierre Bemba Gombo, Sentencia conforme al artículo 74 del ECPI, ICC-01/05- 01/08, de 21 de marzo de 2016" [Reseña], Anuario Iberoamericano de Derecho Internacional Penal, Vol. 5 (2016), pp. 158-168, p. 167.

143 OLASOLO, Tratado de Autoría, cit. nota ${ }^{\circ}$ 32, p. 793

${ }^{144}$ Decisión de confirmación de cargos, ICC-01/05-01/08-424, The Prosecutor v. Jean-Pierre Bemba Gombo, Sala de Cuestiones Preliminares II, Corte Penal Internacional, 3 de julio de 2009, párr. 424.

${ }^{145} \mathrm{Ibid}$

${ }^{146}$ Sentencia de Primera Instancia, ICC-01/05-01/08-3343, The Prosecutor v. Jean-Pierre Bemba Gombo, Sala de Primera Instancia III, Corte Penal Internacional, 21 de marzo de 2016, párr. 213.

147 Opinión Separada de la Jueza Sylvia Steiner a la Sentencia de la Sala de Primera Instancia III, ICC-01/0501/08-3343-AnxI, The Prosecutor v. Jean Pierre Bemba Gombo, Corte Penal Internacional, 21 de marzo de 2016, párrs. 2, 14, 18.

${ }^{148}$ Para la jueza Steiner es necesario ahondar en la relación entre la obligación general de ejercer un control apropiado y las obligaciones específicas, de modo que se entienda que, cuando un superior falla en su obligación de prevenir, incumple con su obligación de ejercer control apropiado; y en el mismo sentido, si un superior falla en su obligación de reprimir, si bien esta surge posteriormente al crimen o mientras este se lleva acabo, se incumple con la obligación general de ejercer un control apropiado, de modo que persiste el vínculo omisivo entre esta obligación general y el crimen. Como consecuencia, desde esta aproximación es posible predicar un nexo causal entre la omisión de las obligaciones de reprimir y remitir la cuestión a la autoridad competente, en el entendimiento de que estas están vinculadas a una obligación previa de carácter general. 
OLASOLO, Héctor; CANOSA, Jannluck. "La Responsabilidad del Superior en el Acuerdo de Paz en Colombia a la luz del Derecho Internacional".

\subsection{Naturaleza jurídica de la Responsabilidad del Superior.}

\subsubsection{La naturaleza de la Responsabilidad del Superior en los arts. 7(3) ETIPY, 6 (3) ETIPR y 6 (3) ECESL.}

La característica más sobresaliente de la RespSup en los arts. 7 (3) ETPIY, 6(3) ETPIR y 6(3) ECESL es la ausencia de un nexo causal entre el incumplimiento del superior y los crímenes internacionales de sus subordinados. De esta manera, la responsabilidad penal del superior no resulta de haber contribuido por omisión a la comisión de dichos crímenes, sino que surge del incumplimiento del deber de adoptar las medidas que el DIP y el DIH le exigen para controlar a sus subordinados (omisión de la conducta esperada) ${ }^{149}$. En consecuencia, pareciera que la naturaleza jurídica de la RespSup en el TIPY, el TIPR y la CESL es la de un delito de omisión propia. ${ }^{150}$

Conforme a la dogmática de los sistemas nacionales romano-germánicos, el resultado de configurar la RespSup como un delito de omisión propia significaría excluir la responsabilidad de los superiores civiles y militares por los crímenes internacionales cometidos sus subordinados. ${ }^{151}$ Los superiores sólo serían responsables por incumplir sus deberes de prevenir, reprimir y enviar la cuestión a las autoridades competentes. En consecuencia, en aplicación del principio de culpabilidad (que requiere adecuar el castigo penal a las características del hecho punible del que surge la responsabilidad), las penas que corresponderían a los superiores deberían ser notablemente más leves que aquellas previstas para los subordinados que son responsables de crímenes internacionales. ${ }^{152}$

\footnotetext{
Esta concepción debe ir acompañada de una definición normativa, y no naturalista de la causalidad, que permita entender que dichas omisiones comportan una fuerza causal que incrementa el riesgo de comisión de crímenes internacionales por los subordinados. El inconveniente que surge con esta aproximación es que en realidad se estaría desarrollando un vínculo de causalidad automático, que desnaturalizaría el concepto de causalidad en los delitos de omisión, que es de entidad hipotética más que normativa. De ahí que, para desentrañar la relación causal no puede adelantarse un juicio de certeza, que se resuelva en términos concluyentes, sino un juicio de probabilidades. En otras palabras, la evaluación que se debe hacer es si la omisión aumentó o no, el riesgo de que se cometiera el ilícito; y en el mismo sentido, si la acción esperada se hubiere dado, se hubiera reducido o no dicho riesgo. Vid. a este respecto, KISS, Alejandro, "La responsabilidad penal del superior ante la Corte Penal Internacional", Zeitschrift fur Internationale Strafrechtsdogmatik, Vol, 2016-1, (2016), pp. 40-66, p. 58.

149 Sentencia de la Sala de Apelación, IT-97-25, The Prosecutor v. Krnojelac, Tribunal Penal Internacional para la ex Yugoslavia, 17 de septiembre de 2003, párr. 171; Sentencia Sala de Primera Instancia, IT-01-48, The Prosecutor v. Halilovic, Tribunal Penal Internacional para la Ex Yugoslavia, 16 de noviembre de 2005, párrs. 75-78; Sentencia sala de primera instancia, IT-01-47, The prosecutor v. Hadzihasanovic \& Kubura, Tribunal Penal Internacional para la Ex Yugoslavia, 15 de marzo de 2006, párrs. 38-42.

${ }^{150}$ GARROCHO, Ana, La Responsabilidad del Superior por Omisión en Derecho Penal Internacional, Navarra: Thomson Reuters 2016. p. 125; OLASOLO, Tratado de Autoría, cit. nota n ${ }^{\circ}$ 32, pp. 809-811

${ }^{151}$ ECKHARDT, “Command Criminal Responsibility”, cit. nota n ${ }^{\circ}$ 43, p. 4.

152 Por esta razón el Código Penal Internacional alemán $(\S \S 13,14)$ ha establecido escalas punitivas más bajas para el incumplimiento por los superiores de los deberes de evitar y castigar. En relación con las violaciones de los deberes de los superiores de castigar, el §14(1) del Código Penal Internacional alemán establece que: "un comandante militar o un superior civil que omite informar, de manera inmediata, cualquier hecho cometido por un subordinado de conformidad con esta ley a la autoridad responsable de su investigación y persecución penal, será castigado con prisión de hasta un máximo de cinco años". La violación de los deberes de los superiores de evitar la comisión de delitos por los subordinados es también considerada por el $\S 13$ (a) y
} 
Sin embargo, si bien la práctica del TPIY, el TPIR y la CESL muestra que las penas por RespSup son inferiores a las impuestas a título de autoría o participación a los subordinados involucrados en crímenes internacionales, lo cierto es que los títulos de imputación y condena cuando se aplica la RespSup siguen haciendo referencia a los crímenes cometidos por los subordinados. Esta práctica es incompatible con la caracterización de la RespSup como un delito de omisión propia. Ante esta situación, algunos autores ${ }^{153}$ han subrayado la necesidad de poner fin a la misma con el fin de que los títulos de imputación y condena por RespSup se limiten al mero incumplimiento de deberes. Esta parece ser también la posición adoptada por el TIPY en el caso Halilovic:

La Sala concluye que según el artículo 7(3) la responsabilidad de mando es responsabilidad por una omisión. El comandante es responsable por no realizar un acto requerido por el Derecho Internacional. Esta omisión es culpable porque el Derecho Internacional impone un deber positivo sobre los superiores de evitar y castigar los delitos cometidos por sus subordinados. Por lo tanto, "por los actos de sus subordinados", como generalmente se refiere en la jurisprudencia del tribunal, no significa que el comandante comparta la misma responsabilidad que los subordinados que cometieron los delitos; por el contrario, más que por los delitos cometidos por sus subordinados, el comandante deberá ser responsable por no actuar. La imposición a un comandante de responsabilidad por el incumplimiento de su deber ha de ser ponderada a luz de los delitos de sus subordinados; un comandante es responsable, no como si hubiera cometido tales delitos por sí mismo; por el contrario, su responsabilidad es considerada en proporción a la gravedad de los delitos cometidos. La Sala considera que esto guarda relación con la lógica de la importancia que el Derecho Internacional Humanitario asigna a los bienes jurídicos protegidos. ${ }^{154}$

Un segundo grupo de autores, afirman, sin embargo, que la naturaleza jurídica de la RespSup no es la de un delito de omisión propia porque no puede encuadrarse en ninguna de las categorías dogmáticas existentes en el Derecho penal comparado, al haber sido desarrollada por el DIP y el DIH al margen de las mismas. ${ }^{155}$ En consecuencia, para estos autores, su naturaleza jurídica, tal y como ha señalado el TIPY en los casos Krnojelac, ${ }^{156}$ Halilovic ${ }^{157}$ y Hadzihasanovic et al, ${ }^{158}$ es sui generis. Esto significaría que la RespSup no se rige por los principios generales del Derecho penal comparado, y que su principal característica es atribuir a los superiores civiles y militares responsabilidad penal por los

(b) del Código Penal Internacional alemán como un delito de omisión propia. De acuerdo con el $\S 13(d)$ : “la violación internacional del deber de supervisar será castigada con prisión hasta un máximo de cinco años, y la violación imprudente del deber de supervisar será castigada con prisión hasta un máximo de tres años".

${ }^{153}$ OLASOLO, Tratado de Autoría, cit. nota n ${ }^{\circ} 32$, pp. 812.

${ }^{154}$ Sentencia Sala de Primera Instancia, IT-01-48, The Prosecutor v. Halilovic, Tribunal Penal Internacional para la Ex Yugoslavia, 16 de noviembre de 2005, párr. 54. En el mismo sentido, Sentencia de Primera Instancia, IT-01-47, The prosecutor v. Hadzihasanovic \& Kubura, Tribunal Penal Internacional para la Ex Yugoslavia, 15 de marzo de 2006, párr. 75.

155 WERLE, Principles, cit. nota ${ }^{\circ}$ 14, p. 128; Sliedregt, E. v. (2012). Individual criminal responsibility in international law. Oxford New York Oxford University Press 2012, p. 206;

156 Sentencia de la Sala de Apelación, IT-97-25, The Prosecutor v. Krnojelac, Tribunal Penal Internacional para la ex Yugoslavia, 17 de septiembre de 2003, párr. 171.

157 Sentencia Sala de Primera Instancia, IT-01-48, The Prosecutor v. Halilovic, Tribunal Penal Internacional para la Ex Yugoslavia, 16 de noviembre de 2005, párr. 75-78.

158 Sentencia sala de primera instancia, IT-01-47, The prosecutor v. Hadzihasanovic \& Kubura, Tribunal Penal Internacional para la Ex Yugoslavia, 15 de marzo de 2006, párr. 38-42. 
OLASOLO, Héctor; CANOSA, Jannluck. "La Responsabilidad del Superior en el Acuerdo de Paz en Colombia a la luz del Derecho Internacional".

crímenes internacionales cometidos por sus subordinados a pesar de la ausencia de un vínculo de causalidad entre el incumplimiento de sus deberes y dichos crímenes. ${ }^{159}$

\subsubsection{La naturaleza jurídica de la Responsabilidad del Superior en el art. 28 ECPI.}

La principal novedad introducida por el art. 28 ECPI en la definición de la RespSup es la exigencia de un nexo de causalidad entre el incumplimiento de los superiores y los crímenes internacionales de sus subordinados. Sin embargo, como hemos visto, la SCP II de la CPI en el caso Bemba ha subrayado que este nexo de causalidad no es aplicable en relación con el incumplimiento de los deberes de reprimir y enviar la cuestión a las autoridades competentes. ${ }^{160}$ En consecuencia, de seguirse esta interpretación, que como hemos visto ha sido cuestionada por la jueza Sylvia Steiner. ${ }^{161}$ la naturaleza jurídica de la RespSup en estos casos sería la misma que la vista en la sección anterior con respecto a los arts. 7(3) ETPIY, 6(3) ETIPR y 6(3) ECESL.

En relación con el deber del superior de tomar todas las medidas necesarias y razonables a su disposición para prevenir la comisión de crímenes internacionales por sus subordinados, la CPI en el caso Bemba ha afirmado de manera inequívoca que la expresión "en razón de no haber ejercido un control apropiado sobre esas fuerzas", recogida en el art. 28(a) y (b) ECPI, introduce un nexo de causalidad entre la omisión del superior y los crímenes de sus subordinados. ${ }^{162}$ Esto significa que, en estos casos, el incumplimiento del superior debe tener un efecto favorecedor del hecho punible para ser penalmente relevante porque lo que se está realmente castigando no es la mera omisión de un deber jurídico, sino la contribución a través de la misma a los crímenes de los subordinados. ${ }^{163}$

Con base en lo anterior, se plantea la cuestión relativa a si la RespSup por omitir su deber de prevenir se configura en el art. 28 ECPI como un supuesto de autoría (comisión por omisión) o de participación (complicidad por omisión). La expresión "en razón de" parece indicar en una primera lectura que los superiores han de ser considerados como autores por comisión por omisión de los crímenes internacionales cometidos por sus subordinados. ${ }^{164}$ Sin embargo, esto exigiría también que los superiores cumplan con los elementos

\footnotetext{
159 ROBINSON, Darryl, "How Command Responsibility Got So Complicated: A Culpability Contradiction, Its Obfuscation, and a Simple Solution”, Melbourne Journal of International Law, Vol. 13, Issue 1 (2012), pp. $1-58$, p. 27.

${ }^{160}$ Decisión de confirmación de cargos, ICC-01/05-01/08-424, The Prosecutor v. Jean-Pierre Bemba Gombo, Sala de Cuestiones Preliminares II, Corte Penal Internacional, 3 de julio de 2009, párr. 424.

161 Opinión Separada de la Jueza Sylvia Steiner a la Sentencia de la Sala de Primera Instancia III, ICC-01/0501/08-3343-AnxI, The Prosecutor v. Jean Pierre Bemba Gombo, Corte Penal Internacional, 21 de marzo de 2016. pp. 2, 14, 18.

162 CPI, sentencia de primera instancia en el caso Bemba, párr. 213; Decisión de confirmación de cargos, ICC01/05-01/08-424, The Prosecutor v. Jean-Pierre Bemba Gombo, Sala de Cuestiones Preliminares II, Corte Penal Internacional, 3 de julio de 2009, párrs. 422, 423.

163 OLASOLO, Tratado de Autoría, cit. nota n ${ }^{\circ} 32$, p. 813.

164 ROXIN, Claus, Autoría y Dominio del hecho en Derecho Penal, Madrid: Marcial Pons, 2016, p. 699; Decisión de confirmación de cargos, ICC-01/05-01/08-424, The Prosecutor v. Jean-Pierre Bemba Gombo, Sala de Cuestiones Preliminares II, Corte Penal Internacional, 3 de julio de 2009, párrs. 425 y 426.
} 
Polít. crim. Vol. 13, № 25 (Julio 2018) Art. 12, pp. 444-500.

[http://www.politicacriminal.cl/Vol_13/n_25/Vol13N25A12.pdf]

subjetivos exigidos para la comisión activa de los crímenes, ${ }^{165}$ situación que no se presenta porque, como hemos visto, el elemento subjetivo del art. 28(a)(i) y (b)(i) ECPI, sólo requiere la imprudencia simple de los superiores militares y la imprudencia grave (o culpa consciente en el mejor de los casos) de los superiores civiles. En ningún caso, por tanto, se requiere que los superiores actúen con el elemento subjetivo general exigido por el art. 30 ECPI para los crímenes de la competencia de la CPI (dolo directo de segundo grado o dolo eventual, dependiendo de su interpretación), como tampoco se requiere que actúen con el dolo especial requerido para autores de ciertos delitos como el genocidio ${ }^{166}$ o el crimen de lesa humanidad de persecución, ${ }^{167}$ por poner sólo algunos ejemplos. ${ }^{168}$ En consecuencia, la naturaleza jurídica de la RespSup por omitir su deber de prevenir se corresponde mucho más con la de una participación punible a título de complicidad por omisión. ${ }^{169}$

\section{La Responsabilidad del Superior en el Derecho Colombiano anterior al Acuerdo y al Acto Legislativo 01/2017}

Hasta el Acuerdo y el Acto Legislativo 01/2017, que regulan entre otros mecanismos de justicia transicional la Jurisdicción Especial para la Paz (JEP), no aparece recogida en ninguna norma legislativa del ordenamiento jurídico colombiano la RespSup (solamente el Derecho operacional de las fuerzas armadas de Colombia se refieren a la misma). Tampoco por vía jurisprudencial se ha introducido en el ordenamiento interno la RespSup tal y como

165 MELONI, Chantal, "Command Responsibility: Mode of Liability for the Crimes of Subordinates or Separate Offence of the Superior?”, Journal of International Criminal Justice ,Vol. 5 (2007), pp. 616-637, pp. 636-637.

${ }^{166} \mathrm{Al}$ respecto, el ECPI establece que se entenderá como genocidio cualquiera de los actos mencionados en el art 6 del mismo, cuando sean "perpetrados con la intención de destruir total o parcialmente a un grupo nacional, étnico, racial, o religioso como tal".

${ }^{167} \mathrm{El}$ art (7)(1) (h) del ECPI establece que se comete el crimen de lesa humanidad de persecución, cuando esta se funde en "motivos políticos, raciales, nacionales, étnicos, culturales, religiosos, de genero [...], u otros motivos". En Los Elementos de los Crímenes del ECPI se señala además que la conducta contra la persona o personas debe haberse cometido \#en razón de la identidad de un grupo o colectividad o contra el grupo o la colectividad como tal".

${ }^{168}$ OLASOLO, Tratado de Autoría, cit. nota ${ }^{\circ}{ }^{32}$, pp. 814-815.

169 MELONI, "Command Responsibility: Mode of Liability", Cit. nota n ${ }^{\circ} 166$, pp. 636-637. De otro modo sería particularmente llamativo que el art. 28(a)(i) ECPI admitiera la comisión por omisión imprudente de los superiores militares como resultado de su omisión imprudente de prevenir que los subordinados cometan crímenes internacionales, cuando, como regla general, el art. 30 ECPI excluye la imprudencia del ámbito del elemento subjetivo general allí establecido. En otras palabras, ¿cómo puede la no evitación imprudente de un delito convertir a un superior en autor de este, si los autores materiales deben actuar, al menos, con dolo eventual para incurrir en responsabilidad penal? No creemos que una cláusula general de participación por omisión imprudente para los superiores militares, aplicable a todos los delitos previstos en el ECPI, esté realmente justificada. La explicación dada por la SCP II en el caso Bemba de que la particular naturaleza y tipo de responsabilidad atribuida a los superiores militares justificarían el castigo de aquellas omisiones imprudentes del deber de prevenir que faciliten la comisión de crímenes internacionales por sus subordinados, no acaba de ser, en nuestra opinión, completamente convincente en un sistema en el que no se prevé, por ejemplo, que esos mismos superiores puedan incurrir en responsabilidad penal a título de autor, o de partícipe, por acciones imprudentes que sean constitutivas de alguno de los elementos objetivos del tipo penal, o que contribuyan sustancialmente a la comisión de los crímenes. En el mismo sentido, DAMASKA, Mirjan, "The Shadow Side of Command Responsibility", The American Journal of Comparative Law, Vol. 49 (2001), pp. 455-496, p. 463, 464; SCHABAS, "General Principles of Criminal", cit. nota o 115, p. 417; AMBOS, "Superior", cit. nota ${ }^{\circ} 17$, p. 852. 
OLASOLO, Héctor; CANOSA, Jannluck. "La Responsabilidad del Superior en el Acuerdo de Paz en Colombia a la luz del Derecho Internacional".

ha sido desarrollada en el DI. De esta manera, lo que se ha venido haciendo es aplicar, particularmente a los superiores militares, las figuras de la comisión por omisión y la autoría mediata a través de aparatos organizados de poder. En consecuencia, todas aquellas omisiones de superiores militares y civiles que no han encontrado encajen en una de estas dos figuras, tal y como han sido aplicadas por la Corte Constitucional de Colombia (CCC) y la Sala de Casación Penal de la Corte Suprema Justicia (SCPCSJ), han sido consideradas como no punibles en Colombia, a pesar de entrar en el ámbito de aplicación de la RespSup conforme al DI. De hecho, algunos de los problemas más graves que presenta la regulación de la RespSup en el Acuerdo y el Acto Legislativo 01/2017 parecen ser consecuencia directa de su limitación jurisprudencial en Colombia a la comisión por omisión y la autoría mediata.

\subsection{La equiparación de la Responsabilidad del Superior a la autoría por comisión por omisión en la jurisprudencia de la Corte Constitucional de Colombia}

A través del Acto Legislativo 02 de 2001 se reformó la Constitución Política de Colombia de 1991 para dar lugar a la adopción del ECPI, de modo que se permitiera su inclusión en el ordenamiento nacional, a pesar de que algunas disposiciones de éste (como la posibilidad de imponer cadena perpetua y la imprescriptibilidad de la acción penal) fueran contrarias a la Constitución. Para abordar este problema, se dispuso en el Acto Legislativo 02/2001 que "[1]a admisión de un tratamiento diferente en materias sustanciales por parte del Estatuto de Roma con respecto a las garantías contenidas en la Constitución tendrá efectos exclusivamente dentro del ámbito de la materia regulada en él". De esta manera, se entiende que el ECPI no vulnera la Constitución de Colombia porque las disposiciones contrarias a esta última solo son aplicables por la CPI, y no por los jueces de la jurisdicción interna. $^{170}$

Posteriormente, con la Ley 742 de 2002, el Congreso de la República aprobó la adopción del ECPI. Esta ley fue objeto de examen de constitucionalidad por la CCC en la Sentencia C-578 de 2002, en la que consideró que, si bien no existe ninguna norma legislativa que recoja expresamente en Colombia la RespSup, el art. 28 ECPI se ajusta a la Constitución de Colombia, señalando que, en la jurisprudencia interna: (i) esta figura se aplica a los superiores militares de jure o de facto a través de la doctrina de la posición de garante (comisión por omisión); y (ii) la extensión de su ámbito de aplicación personal a los superiores civiles se considera un trato diferenciado aprobado por el Acto Legislativo 02/2001y por lo tanto no es aplicable por los jueces internos, sino sólo por la CPI. ${ }^{171}$

La aplicación de la comisión por omisión a los superiores militares ha sido justificada por la CCC por encontrarse los mismos en una posición de garante frente al riesgo de afectar los bienes jurídicos de civiles, que es generado por: (i) la conducta de sus subordinados; y (ii) la conducta de terceros (por ejemplo, miembros de la guerrilla o de grupos paramilitares) que actúan en su área de responsabilidad. ${ }^{172}$ En el mismo sentido, la

\footnotetext{
170 Sentencia C-290 de 2012, Corte Constitucional de Colombia, 18 de abril de 2012.

${ }^{171}$ Sentencia C-578 de 2002, Corte Constitucional de Colombia, 30 de julio de 2002, párr. 6. 2.

172 COTE, Gustavo, "Responsabilidad del superior jerárquico y responsabilidad penal por omisión de miembros de la fuerza pública en Colombia: ¿convergencia entre el derecho penal nacional e internacional?” Revista Colombiana de Derecho Internacional, Vol 28 (2016), pp. 49-112, p. 76.
} 
Polít. crim. Vol. 13, № 25 (Julio 2018) Art. 12, pp. 444-500.

[http://www.politicacriminal.cl/Vol_13/n_25/Vol13N25A12.pdf]

SCPCSJ, en el caso de la Masacre de Mapiripán. ${ }^{173}$ ha señalado que los superiores militares pueden ser responsables penalmente por los hechos de terceros, siempre y cuando ostenten la posición de garantes. En tales casos responderán como autores a título de comisión por omisión, de acuerdo con lo establecido en el art. 25 del Código Penal Colombiano. ${ }^{174}$

Para la CCC esta posición de garante puede surgir de dos fuentes: la primera, es la competencia organizacional, en la que se entiende que, en las sociedades modernas, los ciudadanos pueden crear riesgos jurídicamente tolerables, pero se les exige la adopción de medidas especiales para evitar que dicho riesgo se concrete en la producción de daños antijurídicos. ${ }^{175}$ En consecuencia, los superiores militares tienen la obligación de "tomar medidas especiales para evitar que se concrete el riesgo de afectación de los bienes jurídicos de los ciudadanos derivado de: (i) el tener bajo su control efectivo objetos que son potencialmente peligrosos para los mismos, como por ejemplo las armas; y (ii) la conducta de los subordinados bajo su control efectivo". ${ }^{176}$

Según la CCC, la segunda fuente de la posición de garante de los superiores militares es la competencia institucional, en la que se entiende que, en virtud de relaciones de especial importancia para la sociedad, se imponen deberes específicos a los ciudadanos para salvaguardar ciertos bienes jurídicos de riesgos que no necesariamente han sido creados por los mismos. ${ }^{177}$ De esta manera, como consecuencia del deber irrenunciable que les impone la Constitución de garantizar el orden constitucional y defender los derechos de los ciudadanos, los superiores militares tienen la obligación de tomar medidas especiales para salvaguardar a la población civil cuando un tercero ponga en riesgo sus bienes jurídicos, siempre y cuando esto recaiga dentro de su ámbito de competencia material, funcional y territorial. ${ }^{178}$

Ahora bien, como hemos visto, la comisión por omisión u omisión impropia no se ajusta a la auténtica naturaleza de la RespSup en el art. 28 ECPI, puesto que esta última se configura como (i) una complicidad por omisión en el caso del incumplimiento del deber de prevenir; y (ii) un delito de omisión propia en el caso del incumplimiento de los deberes de reprimir y enviar el asunto a las autoridades competentes. En consecuencia, la comisión por omisión, además de no ser aplicable con respecto al incumplimiento de estos dos últimos deberes, exige como forma de autoría unos requisitos objetivos y subjetivos que no se encuentran en la RespSup por omisión del deber de prevenir. Así, en el plano objetivo requiere un vínculo de causalidad con los delitos de los subordinados, consistente en una "cláusula de equiparación", según la cual la omisión del superior militar debe facilitar de tal

\footnotetext{
${ }^{173}$ En caso de la Masacre de Mapiripán se demostró ante la Corte IDH a través del reconocimiento parcial de responsabilidad del Estado Colombiano y de prueba testimonial que el grupo paramilitar que atacó a la población civil de Mapiripán actuó con la manifiesta colaboración del Ejército Colombiano. Vid. Sentencia de fondo, Serie C No. 134, Caso de la "Masacre de Mapiripán" vs. Colombia, Corte Interamericana de Derechos Humanos, 15 de septiembre de 2005.

${ }^{174}$ Sentencia de la Sala de Casación Penal, Radicación 35113, Caso del General del Ejército Jaime Humberto Uscátegui Ramírez, Corte Suprema de Justicia de Colombia, 5 de junio de 2014.

175 Sentencia SU-1184 de 2001, Corte Constitucional de Colombia, 13 de noviembre de 2001, en lo referente a posición de garante y fuerza pública.

176 Sentencia SU-1184 de 2001, Corte Constitucional de Colombia, 13 de noviembre de 2001.

177 Sentencia SU-1184 de 2001, Corte Constitucional de Colombia, 13 de noviembre de 2001.

${ }^{178}$ Sentencia SU-1184 de 2001, Corte Constitucional de Colombia, 13 de noviembre de 2001.
} 
OLASOLO, Héctor; CANOSA, Jannluck. "La Responsabilidad del Superior en el Acuerdo de Paz en Colombia a la luz del Derecho Internacional".

manera la comisión de los delitos por sus subordinados que el resultado antijurídico no hubiera podido ser alcanzado sin la misma. ${ }^{179}$ Por su parte, en el plano subjetivo, no basta con la omisión imprudente del superior militar a la que se refiere el art. 28 ECPI, sino que requiere que dicha omisión se lleve a cabo con el elemento subjetivo (normalmente dolo) exigido para la comisión activa de los delitos. ${ }^{180}$

En consecuencia, el intento de la CCC de equiparar la RespSup a la comisión por omisión hace que no sean penalmente relevantes la mayoría de las conductas incluidas en aquélla, tales como: (i) el incumplimiento por los superiores militares de su deber de prevenir, en tanto en cuanto (a) no cumpla con la cláusula de equiparación o (b) no se lleve a cabo con el elemento subjetivo exigido para la comisión activa del hecho punible; (ii) todo incumplimiento por los superiores militares de sus deberes de reprimir y someter los crímenes internacionales de sus subordinados a las autoridades competentes; y (iii) todo incumplimiento por los superiores civiles de sus obligaciones de prevenir, reprimir o enviar la cuestión a las autoridades competentes.

\subsection{Los intentos de la Jurisdicción de Justicia y Paz por aplicar la Responsabilidad del Superior y su equiparación por la Sala de Casación Penal de la Corte Suprema de Justicia a la autoría mediata por aparatos organizados de poder.}

El único intento previo al Acuerdo y al Acto Legislativo 01/2017 de aplicar en Colombia la RespSup tal y como ha sido desarrollada por el DIP se encuentra en la jurisdicción de justicia y paz. ${ }^{181}$ Así, en la legalización de cargos contra el jefe paramilitar José Gregorio Mangones Lugo, comandante de un frente del Bloque Norte de las Autodefensas Unidas de Colombia (AUC), la Sala de Justicia y Paz del Tribunal Superior de Bogotá reconoció que no era posible imputar al superior paramilitar los crímenes cometidos por sus subordinados a título de (i) coautoría, porque entre el superior y los subordinados no existía un plan común para cometer los mismos, ni una división de tareas para ejecutar el presunto plan común; o (ii) autoría mediata por aparatos organizados de poder, porque el jefe paramilitar no tenía el dominio del hecho, ni dio una orden para cometer los crímenes, sino que sus subordinados actuaron motu propio. ${ }^{182}$

En vista de lo anterior, la Sala de Conocimiento acudió al Protocolo Adicional II (PA II) para aplicar al superior paramilitar la RespSup, conforme a lo que entendió son sus tres

\footnotetext{
${ }^{179}$ COTE, "Responsabilidad del superior jerárquico", cit. nota $\mathrm{n}{ }^{\circ} 173, \mathrm{p} .76$.

${ }^{180} \mathrm{El}$ art. 21 del Código Penal Colombiano establece que por regla general los tipos contenidos en el mismo se cometen con dolo, y la culpa y la preter-intención solo son punibles en los casos taxativamente señalados por la ley. Vid. Ley 599 de 2000. Por la cual se expide el Código Penal. Diario Oficial de la República de Colombia, No. 44097, de 24 de julio de 2000.

${ }^{181}$ La Salas de Justicia y Paz se crearon en virtud de la ley 975 de 2005, que dispone el componente de justicia en el marco del proceso de Justicia Transicional con el grupo paramilitar "Autodefensas Unidas de Colombia", adelantado por el gobierno del ex presidente Álvaro Uribe Vélez. Para mayor información ver: CUERVO, Jorge; BECHARA, Eduardo; HINESTROZA, Verónica, Justicia transicional: modelos y experiencias internacionales. A propósito de la ley de justicia y paz, Bogotá: Universidad Externado de Colombia, 2007.

${ }^{182}$ Sentencia de Legalización de Cargos, Radicación 1215, Caso de José Gregorio Mangonez, Tribunal Superior de Bogotá (Colombia), Sala de Justicia y Paz, 5 de diciembre de 2011, párr. 572-603, p. 386 y 387.
} 
Polít. crim. Vol. 13, No 25 (Julio 2018) Art. 12, pp. 444-500.

[http://www.politicacriminal.cl/Vol_13/n_25/Vol13N25A12.pdf]

elementos característicos en el DI: (i) la existencia de una relación superior-subordinado; (ii) la omisión del superior de cumplir con su deber jurídico de tomar las medidas necesarias y razonables a su disposición para prevenir, reprimir y enviar la cuestión a las autoridades competentes; y (iii) el conocimiento del superior sobre los crímenes de sus subordinados paramilitares. ${ }^{183}$ Así mismo, la Sala constató que estos tres elementos concurrían en relación con el Sr. Mangones Lugo, por lo que legalizó los cargos que se le imputaban a título de RespSup. ${ }^{184}$

Sin embargo, la SCPCSJ, en su decisión de apelación, consideró que no existía en el ordenamiento jurídico colombiano la RespSup como tal, y que por tanto el modo de imputación debía ser la autoría mediada a través de aparatos organizados de poder. ${ }^{185}$ Según esta última teoría, el superior es responsable en la medida en que tiene el dominio del hecho, entendido como el control sobre la voluntad de sus subordinados, al ser estos últimos meros instrumentos fungibles o intercambiables del superior, que es quien en última instancia determina la realización de los crímenes por sus subordinados. ${ }^{186}$ De este modo, "los comandantes que no participan directamente en la ejecución material del delito no son coautores ni inductores, sino autores mediatos, debido al control o influencia que tuvieron sobre la organización criminal". ${ }^{187}$

Fruto de lo anterior, la SCPCSJ decidió modificar la decisión de la Sala de Justicia y Paz, legalizando los cargos imputados al Sr. Mangones Lugo como autor mediato y no en aplicación de la RespSup. ${ }^{188}$ A partir de esta decisión, las Salas de Justicia y Paz han seguido la doctrina de la SCPCSJ en esta materia, a pesar de continuar considerando que la responsabilidad por autoría mediata no se ajusta plenamente a aquellos casos en los que no está claro que el superior tenga el dominio del hecho sobre los crímenes cometidos por sus subordinados. ${ }^{189}$

El intento de la SCPCSJ de equiparar la RespSup con la autoría mediata por aparatos organizados de poder restringe de manera muy significa el ámbito de aplicación de la primera porque: (i) desde un plano objetivo, además de exigir el control efectivo que el superior ha de tener sobre sus subordinados para que se pueda afirmar la existencia de una relación superior-subordinado, se exige también el control efectivo del superior sobre la

\footnotetext{
183 Sentencia de Legalización de Cargos, Radicación 1215, Caso de José Gregorio Mangonez, Tribunal Superior de Bogotá (Colombia), Sala de Justicia y Paz, 5 de diciembre de 2011, párr. 388 y 389.

184 Sentencia de Legalización de Cargos, Radicación 1215, Caso de José Gregorio Mangonez, Tribunal Superior de Bogotá (Colombia), Sala de Justicia y Paz, 5 de diciembre de 2011, párr. 392 y 393.

${ }^{185}$ Sentencia de la Sala de Casación Penal, Radicación 38250, Caso de José Gregorio Mangonez Lugo y Otro, Corte Suprema de Justicia de Colombia, 26 de septiembre de 2012, p. 20.

${ }^{186}$ Sentencia de la Sala de Casación Penal, Radicación 38250, Caso de José Gregorio Mangonez Lugo y Otro, Corte Suprema de Justicia de Colombia, 26 de septiembre de 2012, p.21.

187 Sentencia de Única Instancia, Radicación 32805, Caso contra el ex senador Álvaro Alfonso García Romero, Corte Suprema de Justicia de Colombia, Sala de Casación Penal, 23 de febrero de 2010, p. 77 y 78.

188 Sentencia de la Sala de Casación Penal, Radicación 38250, Caso de José Gregorio Mangonez Lugo y Otro, Corte Suprema de Justicia de Colombia, 26 de septiembre de 2012, p. 155.

189 Sentencia de Legalización de Cargos, Radicación 1177, Caso de Indalecio José Sánchez Jaramillo, Tribunal Superior de Bogotá (Colombia), Sala de Justicia y Paz, 23 de mayo de 2017.
} 
OLASOLO, Héctor; CANOSA, Jannluck. "La Responsabilidad del Superior en el Acuerdo de Paz en Colombia a la luz del Derecho Internacional".

específica conducta punible de los mismos; ${ }^{190}$ y (ii) desde un plano subjetivo, no basta con la omisión imprudente del superior militar a la que se refiere el art. 28 ECPI, sino que requiere que su conducta se realice con el elemento subjetivo (normalmente dolo) exigido para la comisión activa de los crímenes. ${ }^{191}$ Además, dado el ámbito restringido de organizaciones en el que es aplicable la autoría mediata por aparatos organizados de poder, ${ }^{192}$ las omisiones de los superiores civiles quedan en gran medida fuera su ámbito de aplicación.

En consecuencia, el intento de la SCPCSJ de equiparar la RespSup a la autoría mediata por aparatos organizados de poder hace que no sean penalmente relevantes la mayoría de las conductas incluidas en aquélla, tales como: (i) el incumplimiento por los superiores militares de su deber de prevenir, en tanto en cuanto (a) no tenga el impacto necesario sobre la conducta punible del subordinado como para afirmar que el superior ejerció el control efectivo sobre la misma; o (b) no se lleve a cabo con el elemento subjetivo exigido para la comisión activa del hecho punible; (ii) todo incumplimiento por los superiores militares de sus deberes de reprimir y enviar los crímenes internacionales de sus subordinados a las autoridades competentes (la omisión del superior no puede generar impacto ninguno sobre los crímenes previamente consumados de sus subordinados); y (iii) todo incumplimiento por los superiores civiles de sus obligaciones de prevenir, reprimir o enviar la cuestión a las autoridades competentes, que se produzca en el seno de organizaciones que no cumplen con las característica necesarias para la aplicación de la autoría mediata a través de aparatos organizados de poder. Como veremos más adelante, este mismo problema se va a reproducir, en buena medida, en la regulación de la RespSup por el Acuerdo ${ }^{193}$ y el Acto Legislativo 01/2017 ${ }^{194}$ en relación con los agentes del Estado.

\subsection{El tratamiento de la Responsabilidad del Superior en el Derecho Operacional de las Fuerzas Armadas Colombianas.}

Hasta el Acuerdo y el Acto Legislativo 01/2017 la RespSup aparece únicamente recogida en Colombia en el Derecho operacional de las fuerzas armadas. Así, en el documento de 2007 sobre política integral de DDHH y DIH del Ministerio de Defensa, se hace énfasis en la necesidad de "desarrollar un verdadero derecho operacional", de modo que sus instrucciones sean más claras para las unidades militares, "al integrar los tratados, los convenios y la jurisprudencia internacional con la normativa nacional". ${ }^{195}$ Dentro de los aspectos más relevantes a que se refiere esta política integral se encuentra el relativo a la

\footnotetext{
190 Sentencia de la Sala de Casación Penal, Radicación 38250, Caso de José Gregorio Mangonez Lugo y Otro, Corte Suprema de Justicia de Colombia, 26 de septiembre de 2012, p. 42-47.

${ }^{191}$ Sentencia de la Sala de Casación Penal, Radicación 38250, Caso de José Gregorio Mangonez Lugo y Otro, Corte Suprema de Justicia de Colombia, 26 de septiembre de 2012, p. 44.

192 OLASOLO, Tratado de Autoría, cit. nota n ${ }^{\circ} 32$, pp. 300 et seq.

${ }^{193}$ GOBIERNO DE COLOMBIA Y FARC-EP, Acuerdo de 24 de noviembre de 2016, cit. nota n ${ }^{\circ} 1$, p. 152.

${ }^{194}$ Acto Legislativo 01/2017. Por medio del cual se crea un título de disposiciones transitorias de la Constitución para la terminación del conflicto armado y la construcción de una paz estable y duradera y se dictan otras disposiciones. Diario Oficial de la República de Colombia, No. 50196 de 4 de abril de 2017, art. 24.

195 MINISTERIO DE DEFENSA DE COLOMBIA, Política Integral de DDHH y DIH [En línea], 2008, disponible en https://www.fac.mil.co/sites/default/files/Politica_DDHH_MDN.pdf. [fecha de consulta: 14/08/2017], párr. 32 y 33.
} 
Polít. crim. Vol. 13, № 25 (Julio 2018) Art. 12, pp. 444-500.

[http://www.politicacriminal.cl/Vol_13/n_25/Vol13N25A12.pdf]

implementación de la RespSup, ya que los superiores militares deben tener suficiente claridad sobre el marco jurídico en el que operan y la disciplina operacional que deben imponer a sus subordinados, para lo cual es necesario integrar los estándares internacionales en la legislación nacional. ${ }^{196}$

Con este fin, la guía elaborada en 2009 bajo el título [l]os Derechos Humanos y el Derecho internacional humanitario: hoja de ruta del Ejercito Nacional desarrolla la RespSup. Para ello comienza señalando que "[a]1 interior de las Fuerzas Militares es frecuente escuchar que los comandantes no solo deben responde por sus actos, sino que también deben hacerlo por lo que hagan o dejen de hacer los hombres que se encuentran bajo su mando. Esta afirmación, extrema en apariencia, es real [...]". ${ }^{197}$ Tras afirmar la existencia de la RespSup, la guía procede a identificar a los superiores militares, limitando esta condición a aquellos que por mandato legal y en atención a su grado, jerarquía y cargo, ejercen, sobre una unidad militar, el mando y control (definido como la autoridad o el poder que se ejerce sobre un grupo de personas para instruir, conducir, dirigir, limitar y emplear de acuerdo al propio criterio dentro del marco legal). ${ }^{198}$

A continuación, la guía describe el tratamiento que tiene la RespSup en el Derecho colombiano, subrayando que los superiores militares pueden ser responsables por omisión bajo el art. 25 del Código Penal Colombiano por las acciones que dejan de tomar, cuando están jurídicamente obligados a adoptarlas. Según la guía, esta obligación se activa como consecuencia de la posición de garante en que se encuentran los superiores militares dentro de su "ámbito de dominio" (ámbito territorial de competencia). Además, prosigue la guía, para que incurran en responsabilidad es necesario que los superiores militares tengan conocimiento previo de que se van a cometer los crímenes (no es suficiente con la mera imprudencia) y contar con los medios necesarios para poder evitarlos. ${ }^{199}$

La guía da a entender también que la regulación de la RespSup en el DI abarca un ámbito más amplio de conductas, haciendo particular hincapié en que desde un punto de vista subjetivo es suficiente para incurrir en responsabilidad con que los superiores militares hayan omitido sus deberes habiendo tenido razones para saber que sus subordinados estaban cometiendo crímenes internacionales o se proponían cometerlos. ${ }^{200}$

La guía de 2009 presenta, por tanto, un entendimiento de la relación superior-subordinado y del requisito del control efectivo fuertemente determinado por el nombramiento formal o de

\footnotetext{
${ }^{196}$ MINISTERIO DE DEFENSA DE COLOMBIA, Política Integral de DDHH, cita. nota n ${ }^{\circ}$ 196, párr. 35.

197 EJÉRCITO NACIONAL DE COLOMBIA, Los derechos humanos y el derecho internacional humanitario. hoja de ruta del Ejército Nacional, Bogotá: Editorial Ejército Nacional de Colombia, 2009, p. 247.

${ }^{198}$ EJÉRCITO NACIONAL DE COLOMBIA, Los derechos humanos, cit. nota n ${ }^{\circ}$ 198, p. 249. Así mismo, se señala que el mando puede ser conjunto, cuando se otorga atribuciones al comandante de una organización militar conjunta; directo, cuando se reconoce autoridad para emitir órdenes a sus unidades subordinadas; operacional o delegado, cuando se autoriza a un superior para asignar misiones y reasignar fuerzas; y operacional funcional, que es un tipo especial de mando cuando se autorizan operaciones conjuntas para el desarrollo de la operación, primando la responsabilidad operacional principal. Vid. EJÉRCITO NACIONAL DE COLOMBIA, Los derechos humanos, cit. nota ${ }^{\circ}{ }^{\circ} 198$, p. 250.

${ }^{199}$ EJÉRCITO NACIONAL DE COLOMBIA, Los derechos humanos, cit. nota ${ }^{\circ}{ }^{\circ}$ 198, p. 252.

${ }^{200}$ EJÉRCITO NACIONAL DE COLOMBIA, Los derechos humanos, cit. nota ${ }^{\circ}{ }^{\circ} 198$, p. 253.
} 
OLASOLO, Héctor; CANOSA, Jannluck. "La Responsabilidad del Superior en el Acuerdo de Paz en Colombia a la luz del Derecho Internacional".

jure del superior militar, a pesar de que como hemos visto, dicha designación solo constituye un indicio de la existencia de la capacidad material para prevenir, reprimir o enviar la cuestión a las autoridades competentes. Además, la guía vincula la posición de garante al ámbito de competencia territorial del superior. Esta vinculación, si bien es entendible dentro de la doctrina de la posición de garante que ha sostenido la jurisprudencia de la CCC, no constituye un requisito conforme al art. 28 ECPI. Finalmente, en relación con el grado de conocimiento que debe tener el superior militar, la guía descarta el estándar de imprudencia simple "hubiere debido saber", limitando el elemento subjetivo al "conocimiento" o a la imprudencia grave recogida en la expresión "tener razones para saber".

En consecuencia, se puede afirmar que el Derecho operacional desarrollado entre 2007 y 2010, si bien supuso un primer paso en la introducción de la RespSup en el Derecho operacional de las fuerzas armadas de Colombia, no cumplió con el objetivo de la Política de DDHH y DIH de integrar la regulación internacional de dicha figura en la normativa nacional, para dotar así de mayor claridad a los superiores militares sobre su responsabilidad por los crímenes internacionales de sus subordinados.

Una vez avanzadas las negociaciones con las FARC-EP, el nuevo gobierno de Juan Manuel Santos diseñó la Estrategia Nacional para la Garantía de los Derechos Humanos 20142034. ${ }^{201}$ En este nuevo instrumento de política pública, se dispone la capacitación especializada de los superiores militares en la investigación, el juzgamiento y la sanción de las graves violaciones a los DDHH y al DIH. Así mismo, se prevé la elaboración de protocolos de investigación especializados, en cuyo desarrollo se pretende involucrar a las fuerzas armadas y a la justicia penal militar. ${ }^{202}$

Este proceso de actualización está relacionado con el Plan Minerva, que puso en marcha la reforma de la doctrina militar con un énfasis en la modernización y el mejoramiento táctico del Ejército de Colombia. ${ }^{203}$ En desarrollo de este plan se publicó el 7 de agosto de 2016 la nueva doctrina militar "Damasco", contenida en 17 manuales de operaciones, denominados Manuales Fundamentales del Ejercito (MFE). ${ }^{204}$ Entre los mismos, tiene particular relevancia para este trabajo el manual "MFE 6-27 Derecho Operacional Terrestre", ${ }^{205}$ donde se regula la RespSup en los siguientes términos:

${ }^{201}$ CONSEJERÍA PRESIDENCIAL PARA LOS DERECHOS HUMANOS, Estrategia Nacional para la Garantía de los Derechos Humanos 2014-2034, Bogotá: Imprenta Nacional, 2015.

${ }^{202}$ CONSEJERÍA, Estrategia Nacional para la Garantía, cita. nota ${ }^{0}$ 202, p. 120.

${ }^{203}$ Educación, en la base de nueva estrategia del Ejército. El tiempo. 11 de junio de 2015. [Fecha de consulta: 19 de julio de 2017]. Disponible en http://www.eltiempo.com/archivo/documento/CMS-15935355.

${ }^{204}$ EJÉRCITO NACIONAL DE COLOMBIA, Manuales Fundamentales de Ejército [En línea], 20 de diciembre de 2016. [Fecha de consulta: 13 de agosto de 2017]. Disponibles en https://ejercito.mil.co/centro_educacion_militar/examenes_competencia/manuales_fundamentales_ejercito_4 07139

${ }^{205}$ EJÉRCITO NACIONAL DE COLOMBIA, MFE 6-27 Derecho Operacional Terrestre [En línea], 20 de diciembre de 2016. [Fecha de consulta: 13 de agosto de 2017]. Disponibles en https://ejercito.mil.co/centro_educacion_militar/examenes_competencia/manuales_fundamentales_ejercito_4 07139 
Polít. crim. Vol. 13, No 25 (Julio 2018) Art. 12, pp. 444-500.

[http://www.politicacriminal.cl/Vol_13/n_25/Vol13N25A12.pdf]

"[4-2] Por otra parte, los comandantes militares son responsables como superiores cuando:1) El comandante sabe de la comisión de un ilícito y no toma las medidas necesarias y razonables para prevenirlo. 2) El comandante tiene razones para saber que se va a cometer un acto ilícito. 3) El comandante no sabe del ilícito, pero después de ocurrido no toma las medidas necesarias para garantizar su investigación, penal y disciplinaria.

[4-3] Para efectos de que se establezca responsabilidad del comandante, deben tenerse en cuenta los siguientes elementos: 1) El control efectivo. 2) El conocimiento del acto ilícito. 3) Las medidas razonables y necesarias para prevenir, investigar y sancionar.

[4-4] Se entiende por "control efectivo" la capacidad material que tiene el superior sobre los actos de sus subordinados y, en ese sentido, se trata de un poder de control real, como dar órdenes y hacerlas ejecutar, conducir operaciones que sean ejecutadas por sus subalternos, imponer sanciones y relevar del cargo a sus subalternos.

[4-5] El comandante debe emplear los medios disponibles en la doctrina, con el fin de prevenir de forma eficiente y efectiva la ocurrencia de actos ilícitos, de los cuales debe dejar registro; así mismo, aplicar el Mando Tipo Misión (MTM) para lograr el balance entre el arte del mando y la ciencia del control". ${ }^{206}$

Esta disposición constituye un paso adicional en el proceso de integración de la normativa internacional sobre la RespSup en el Derecho operacional de las fuerzas armadas de Colombia. Así, se observa una mayor coherencia con el DI en: (i) la definición de control efectivo, que ahora sí se fundamenta en la competencia material, y no se restringe al contorno legal y/o jurisdiccional; y (ii) la determinación con mayor claridad de las obligaciones de los superiores jerárquicos (prevenir, que incluye el poner fin a los crímenes de los subordinados, investigar y sancionar), cuyo incumplimiento da lugar a responsabilidad

Sin embargo, se observan todavía ciertas desviaciones del régimen jurídico de la RespSup previsto en el art. 28 ECPI. Así, en lo que tiene que ver con el elemento subjetivo se exige que el superior militar conozca, o al menos tenga razones para saber, pero se ignora una vez más el estándar de imprudencia simple "hubiere debido saber" contenido en el art. 28(a)(i) ECPI. Además, tampoco se recoge el efecto favorecedor que la omisión del deber de prevenir del superior militar debe tener en la comisión del hecho punible del subordinado. Finalmente, como no podía ser de otra manera en un manual de Derecho operacional de las fuerzas armadas, el mismo no aborda la RespSup en relación con los superiores civiles.

\section{La Responsabilidad del Superior en el Acuerdo y el Acto Legislativo 01/ 2017.}

\subsection{Primera aproximación al tratamiento de la Responsabilidad del Superior en el Acuerdo y el Acto Legislativo 01/2017}

El Gobierno de Colombia y las FARC-EP han establecido en el Acuerdo el llamado Sistema Integral de Verdad, Justicia, Reparación y No Repetición, que crea, entre otras instituciones de justicia transicional, la Jurisdicción Especial para la Paz. Como parte del Acuerdo han previsto expresamente la RespSup (referida en el mismo como "responsabilidad del mando") para quienes han ostentado la posición de superior en la

${ }^{206}$ EJÉRCITO NACIONAL DE COLOMBIA, MFE 6-27 Derecho Operacional, cit. nota. $\mathrm{n}^{0}$ 206, p. 14. 
OLASOLO, Héctor; CANOSA, Jannluck. "La Responsabilidad del Superior en el Acuerdo de Paz en Colombia a la luz del Derecho Internacional".

Fuerza Pública colombiana y en las FARC-EP. En relación con los primeros, el numeral 44 de la página 152 dispone:

"En concordancia con lo anterior, respecto a los agentes del Estado, se establece un tratamiento especial, simultáneo, equilibrado y equitativo basado en el DIH. Dicho tratamiento diferenciado valorará lo establecido en las reglas operacionales de la fuerza pública en relación con el DIH. En ningún caso la responsabilidad del mando podrá fundarse exclusivamente en el rango, la jerarquía o el ámbito de jurisdicción. La responsabilidad de los miembros de la fuerza pública por los actos de sus subordinados deberá fundarse en el control efectivo de la respectiva conducta, en el conocimiento basado en la información a su disposición antes, durante y después de la realización de la respectiva conducta, así como en los medios a su alcance para prevenir, y de haber ocurrido, promover las investigaciones procedentes."

La definición de la RespSup en relación con los mandos guerrilleros añade a lo anterior un párrafo final en el que se indica que "[s]e entiende por control efectivo de la respectiva conducta, la posibilidad real que el superior tenía de haber ejercido un control apropiado sobre sus subalternos, en relación con la ejecución de la conducta delictiva, tal y como se establece en el derecho internacional". ${ }^{207}$

Las diferencias en la definición de la RespSup para los miembros de la Fuerza Pública y las FARC-EP se debe a un cambio de última hora realizado unilateralmente por el presidente Juan Manuel Santos sobre el texto final del Acuerdo. ${ }^{208}$ Con respecto al mismo, Human Rights Watch ha subrayado que "el gobierno eliminó un párrafo que había sido agregado al nuevo texto y que acercaba el principio de "responsabilidad del mando" incluido en el acuerdo a la definición consagrada en el derecho internacional", ${ }^{209}$ luego de que "oficiales activos y retirados del Ejército presentaran quejas sobre esta disposición". ${ }^{210}$

La Fiscalía de la CPI también ha mostrado su inquietud ante la definición en el Acuerdo de la RespSup en relación con los agentes del Estado. En su Informe de noviembre de 2016 sobre la actividades de examen preliminar en la situación de Colombia, indica que dicha entidad no ha tomado todavía ninguna posición acerca del Acuerdo de Paz y mantiene bajo observación la posible existencia de lagunas sustantivas "en las leyes aplicadas por las autoridades competentes de la Jurisdicción Especial para la Paz, como las relativas a la Responsabilidad del Superior, que podría socavar su capacidad para proceder de manera genuina en relación con los casos potenciales que podrían surgir de una investigación en la

\footnotetext{
${ }^{207}$ GOBIERNO DE COLOMBIA Y FARC-EP, Acuerdo de 24 de noviembre de 2016, cit. nota ${ }^{\circ} 1$, P. 164.

${ }^{208}$ Un mico en el acuerdo [En línea]. La Patria. 27 de noviembre de 2016. [Fecha de consulta: 21 de agosto de 2017]. Disponible en http://www.lapatria.com/nacional/un-mico-en-el-acuerdo-332510; y Críticas de Human Rights Watch por cambios de última hora en el acuerdo [En línea]. El Espectador. 24 de noviembre de 2016. [Fecha de consulta: 21 de agosto de 2017]. Disponible en http://www.elespectador.com/noticias/paz/criticasde-human-rights-watch-cambios-de-ultima-hora-e-articulo-667296.

209 Vivanco está "decepcionado" por cambio en Acuerdo de Paz [En línea]. El Tiempo. 25 de noviembre de 2016. [Fecha de consulta: 4 de agosto de 2017]. Disponible en http://www.eltiempo.com/politica/proceso-depaz/vivanco-esta-decepcionado-por-cambio-en-acuerdo-final/16759214\#sthash.ZoWnDHKW.dpuf

${ }^{210}$ VIVANCO, Carta sobre “Responsabilidad de mando”, Cit. nota. $\mathrm{n}^{0} 10$.
} 
Polít. crim. Vol. 13, No 25 (Julio 2018) Art. 12, pp. 444-500.

[http://www.politicacriminal.cl/Vol_13/n_25/Vol13N25A12.pdf]

situación". 211 Posteriormente, en una carta enviada a la Revista Semana el 21 de enero de 2017, la Fiscal de la CPI observa con preocupación "que en la versión final del acuerdo de paz se ha eliminado toda referencia directa al correspondiente artículo 28 del estatuto". ${ }^{212}$ Sin embargo, muestra su esperanza de que la definición finalmente adoptada por los legisladores al implementar el Acuerdo en el ordenamiento jurídico colombiano se ajuste plenamente al ECPI. ${ }^{213}$

Sin embargo, ninguna de estas preocupaciones han sido atendidas por el poder legislativo colombiano. De esta manera, ni la regulación del elemento de control efectivo, ni la del elemento subjetivo (aspectos sobre los que la Fiscal de la CPI ha expresado una particular preocupación) han sido ajustados por el Acto Legislativo 01/2017 a su regulación en el DI. Así, el art. 24 transitorio de dicho Acto Legislativo dispone que "[p]ara la determinación de la responsabilidad del mando, la Jurisdicción Especial para la Paz aplicará, en el caso de los miembros de la Fuerza Pública, el Código Penal colombiano, el Derecho Internacional Humanitario como ley especial, y las reglas operacionales de la Fuerza Pública en relación con el DIH siempre que ellas no sean contrarias a la normatividad legal’. Así mismo, esta disposición, además de recordarnos que "[1]a determinación de la responsabilidad del mando no podrá fundarse exclusivamente en el rango, la jerarquía o el ámbito de jurisdicción”, establece que "[1]a responsabilidad de los miembros de la Fuerza Pública por los actos de sus subordinados deberá fundarse en el control efectivo de la respectiva conducta, en el conocimiento basado en la información a su disposición antes, durante, o después de la realización de la respectiva conducta, así como en los medios a su alcance para prevenir que se cometa o se siga cometiendo la conducta punible, siempre y cuando las condiciones fácticas lo permitan, y de haber ocurrido, promover las investigaciones procedentes". De esta manera, el control efectivo que se exige a los superiores de la Fuerza Pública para incurrir en RespSup, se extiende más allá de la capacidad material de control sobre los propios subordinados exigida por el DI, para abarcar también la específica conducta punible de los mismos.

El párrafo final del art. 24 transitorio del Acto Legislativo 01/2017, profundiza en este problema al definir lo que se entiende por "mando y control efectivo del superior militar o policial sobre los actos de sus subordinados". Según la definición allí recogida, éste sólo existirá cuando se puedan probar las siguientes condiciones concurrentes: a. Que la conducta o las conductas punibles hayan sido cometidas dentro del área de responsabilidad asignada a la unidad bajo su mando según el nivel correspondiente y que tengan relación con actividades bajo su responsabilidad; b. Que el superior tenga la capacidad legal y material de emitir órdenes, de modificarlas o de hacerlas cumplir; c. Que el: superior tenga la capacidad efectiva de desarrollar y ejecutar operaciones dentro del área donde se cometieron los hechos punibles, conforme al nivel de mando correspondiente; d. Que el superior tenga la capacidad material y directa de tomar las medidas adecuadas para evitar o

\footnotetext{
${ }^{211}$ OFICINA DE LA FISCAL DE LA CPI, Informe sobre Exámenes Preliminares, situación en Colombia [En línea], 2016, disponible en https://www.icc-cpi.int/iccdocs/otp/161114-otp-rep-PE-Colombia.pdf, [fecha de consulta: 14/08/2017], párr. 257.

212 BENSOUDA, Fatou, El acuerdo de paz de Colombia demanda respeto pero también responsabilidad [En línea], 21 de enero de 2017, disponible en: http://www.semana.com/nacion/articulo/deseo-corte-penalinternacional-justicia-transicional-en-colombia/512820. [fecha de consulta: 04/08/2017].

${ }^{213}$ BENSOUDA, El acuerdo de paz, Cit. nota. $\mathrm{n}^{\circ} 213$.
} 
OLASOLO, Héctor; CANOSA, Jannluck. "La Responsabilidad del Superior en el Acuerdo de Paz en Colombia a la luz del Derecho Internacional".

reprimir la conducta o las conductas punibles de sus subordinados, siempre y cuando haya de su parte conocimiento actual o actualizable de su comisión. ${ }^{214}$

En este contexto, la Fiscalía de la CPI envió el 9 de julio de 2017 una comunicación al Gobierno de Colombia en el que daba a conocer los nombres de 23 generales y 6 coroneles sobre los que existen indicios de su presunta responsabilidad por haber comandado unidades implicadas en 1228 hechos de ejecuciones extrajudiciales, denominadas falsos positivos. ${ }^{215}$ Así mismo, la Fiscalía subrayó que, si la justicia ordinaria o la Jurisdicción Especial para la Paz no hacen lo suficiente para investigar, enjuiciar y sancionar a los presuntos responsables, corresponderá a la CPI adelantar los procesos. ${ }^{216}$

\subsection{La cuestión relativa a las fuentes de la Responsabilidad del Superior.}

El chapeau del art. 24 transitorio del Acto Legislativo 01/2017 prevé que, para determinar la RespSup entre los mandos de la Fuerza Pública colombiana, la JEP deberá aplicar el Código penal, el DIH como ley especial, y las reglas operacionales de la Fuerza Pública siempre no sean contrarias a la normatividad legal. Como ya hemos visto, sin embargo, el Código penal de Colombia no recoge expresamente la RespSup y los intentos de la CCC y la SCPCSJ por equipararla con las figuras de la comisión por omisión y la autoría mediata por aparatos organizados de poder restringen de manera muy significativa su ámbito de aplicación.

En cuanto a la aplicación del DIH como ley especial, conviene subrayar que esta posición doctrinal, que excluye en los conflictos armados la aplicación del DIDH en tanto en cuanto pueda resultar contrario al DIH, se encuentra superada tanto en la jurisprudencia como en la doctrina. Así, la Corte IDH, entiende que el DIH es lex especialis no en el sentido de que este desplace la aplicación de las normas del DIDH que le sean contrarias (regla tradicional de resolución de anomias normativas), sino que, en vista de su carácter especializado, ofrece en determinadas situaciones mayor grado de protección que el DIDH, de modo que resulta útil para interpretar de forma más amplía las garantías de la $\mathrm{CADH}$ en el marco del conflicto armado. ${ }^{217}$

Por su parte, el TEDH ha llegado a rechazar la consideración del DIH como ley especial frente al DIDH, para indicar que, en algunos casos, como los que tienen que ver con el derecho a la vida, el DIDH se convierte en ley especial frente al DIH, de modo que este último se debe interpretar conforme al primero. ${ }^{218}$

\footnotetext{
${ }^{214}$ Acto Legislativo 01/2017. Por medio del cual se crea un título de disposiciones transitorias de la Constitución para la terminación del conflicto armado y la construcción de una paz estable y duradera y se dictan otras disposiciones. Diario Oficial de la República de Colombia, No. 50196 de 4 de abril de 2017, art. 24.

${ }^{215}$ El informe aún no se encuentra disponible al público. Vid Supra: cit. nota n. ${ }^{0} 12$.

${ }^{216}$ Supra: cit. nota n. $^{0} 12$.

${ }^{217}$ SALMON, Elizabeth, "Institutional Approach between IHL and IHRL: Current trends in the jurisprudence of the Inter-american Court of Human Rights" Journal of International Humanitarian Legal Studies, Vol. 5, Issue 1-2 (2014), pp. 152-185, pp. 165-168.

${ }^{218}$ CHEVALIER, Juliet, "Has human rights law become lex specialis for the European Court of Human Rights in right to life cases arising from internal armed conflicts", The International Journal Of Human Rights, Vol. 14, Issue 4 (2010), pp. 584-602
} 
En la misma línea se debe entender la jurisprudencia de la Corte Internacional de Justicia (CIJ) que, en sus Opiniones Consultivas sobre el Muro de en Palestina y Armas Nucleares, afirma que cuando se invoca la aplicación del DIH como lex especialis se debe entender más como una regla hermenéutica según la cual los tratados han de interpretarse a la luz de cualquier otra obligación que vincula a las partes, que como la aplicación de la regla lex especialis derogat legi generali. ${ }^{219}$

También en la doctrina se observa un paulatino abandono de la concepción del DIH como norma que desplaza al DIDH, en aras de su consideración como instrumento de interpretación del DIDH y viceversa. Conforme a esta última posición, ambos cuerpos normativos son complementarios y se aplican de modo confluyente. ${ }^{220}$

Finalmente, el chapeau del art. 24 transitorio del Acto Legislativo 01/2017 hace también referencia a la aplicación de las reglas operacionales de la Fuerza Pública siempre que no sean contrarias a la normatividad legal, lo que incluye también el Bloque de Constitucionalidad, en el cual se entienden integrados los tratados que conforman el DIDH y el DIH. ${ }^{221}$ Lo paradójico es que el Acto Legislativo 01/2017 dota de naturaleza constitucional al propio art. 24 transitorio, generando con ello un conflicto normativo entre las reglas del DI integradas en la Constitución a través del Bloque de Constitucionalidad y la norma en mención que resulta contraria a este en varios aspectos. Además, se impide aplicar aquellas normas del Derecho operacional que, como el Manual MFE 6-27 sobre Derecho Operacional Terrestre, contienen una definición de la RespSup notablemente más cercana a los estándares internacionales que lo dispuesto en el art. 24 transitorio.

\subsection{La relación superior-subordinado: la extensión del control efectivo sobre los subordinados al control efectivo sobre sus conductas punibles}

El art. 24 transitorio continua su elaboración de la RespSup señalando acertadamente que esta no podrá fundarse exclusivamente "en el rango, la jerarquía o el ámbito de jurisdicción", lo que resulta coherente con su regulación internacional, porque estos solo son factores indiciarios de la existencia de una relación de subordinación, pero no son suficientes para demostrarla, ni para desacreditarla. En última instancia, lo que se debe probar es la capacidad material del superior para prevenir, reprimir o remitir a la autoridad competente los crímenes internacionales de sus subordinados. ${ }^{222}$

\footnotetext{
219 BORELLI, Silvia, "The (Mis)-Use of General Principles of Law: Lex Specialis and the Relationship between International Human Rights Law and the Laws of Armed Conflict" en PINESCHI, Laura (Ed.), General Principles of Law - The Role of the Judiciary. Heildelberg: Springer, 2015, pp. 265-295..

${ }^{220}$ MILANOVIC, Marko, “The lost origins of lex specialis: rethinking the relationship between human rights and international humanitarian law" en OHLIN. Jens, Theoretical boundaries of armed conflict and human rights, Cambridge: Cambridge University Press, 2016, pp. 78-117.

221 SUELT, Vanessa, "El Bloque de Constitucionalidad como mecanismo de interpretación constitucional. Aproximación a los contenidos del Bloque en derechos en Colombia”, Vniversitas, Vol. 65, Núm. 133 (2016), pp. 302-381, pp. 327 y 328.

222 Vid supra: sección 2.3.1.
} 
OLASOLO, Héctor; CANOSA, Jannluck. "La Responsabilidad del Superior en el Acuerdo de Paz en Colombia a la luz del Derecho Internacional".

Los problemas comienzan cuando el texto define qué se entiende por "mando y control efectivo. En efecto, la norma señala que "[1]a responsabilidad de los miembros de la Fuerza Pública por los actos de sus subordinados deberá fundarse en el control efectivo de la respectiva conducta". Sin embargo, como hemos visto, la relación de subordinación se tiene que ejercer sobre las unidades subordinadas que planean o llevan a cabo los crímenes, no sobre la conducta punible como tal. De otro modo, al exigirse al superior el control efectivo de las específicas conductas punibles de sus subordinados, lo que se está haciendo es importar elementos propios de ciertas formas de autoría, como las que requieren el dominio del hecho (en particular, la autoría mediata), a la RespSup, que en el DI dista mucho de tener dicha naturaleza, al configurarse como un delito de omisión propia o, en el caso del incumplimiento de la obligación de prevenir, como una forma de participación por complicidad dolosa o imprudente. ${ }^{223}$

El art. 24 transitorio establece además cuatro condiciones concurrentes que se deben demostrar para que se entienda que el superior militar o policial tiene "mando y control efectivo". En primer lugar, se exige que la conducta punible haya sido cometida "dentro del área de responsabilidad asignada a la unidad bajo su mando" y "que tenga relación con actividades bajo su mando". Este último requisito extiende a los superiores militares una limitación de responsabilidad que el art. 28(b) ECPI recoge exclusivamente para los superiores civiles. Esta extensión no tiene, en nuestra opinión, ninguna justificación porque mientras el superior civil tiene sobre sus subordinados un grado de influencia limitado al ámbito de su actividad laboral, en el ámbito militar, el control del superior se extiende a todos los aspectos de la vida castrense. ${ }^{224}$ Además, la exigencia de que la conducta punible haya sido cometida dentro del área de responsabilidad asignada se olvida de que para el DIP lo relevante es la capacidad material del superior y no la atribución normativa.

Como segunda condición, se exige que el superior tenga la capacidad legal y material de emitir órdenes y de hacerlas cumplir, lo que excluiría la responsabilidad de los superiores de facto, quienes a pesar de no haber sido designados legalmente pueden contar con autoridad y control efectivo al tener la capacidad material para emitir ordenes, hacerles seguimiento y exigir su cumplimiento. ${ }^{225}$

Como tercera condición se establece que el superior militar debe tener la capacidad efectiva de desarrollar y ejecutar operaciones dentro del área donde se cometieron los hechos punibles, conforme al nivel de mando correspondiente. Con este requisito se adiciona al concepto de control efectivo, el control del superior sobre el área geográfica donde se cometieron los crímenes. Esta exigencia desfigura el concepto de control efectivo sobre las fuerzas o unidades militares, pues bien puede ocurrir que el superior pueda materialmente dar órdenes de desplazamiento a áreas fuera de su zona geográfica de influencia, y aun así conservar el control efectivo sobre sus subordinados. El caso Bemba es ilustrativo de esta situación, puesto que, según los hechos del caso, Bemba mantuvo control efectivo sobre las fuerzas del Movimiento para la Liberación del Congo mientras desarrollaban operaciones

\footnotetext{
${ }^{223}$ OLASOLO, Tratado de Autoría, cit. nota ${ }^{\circ}$ 32, p. 815.

${ }^{224}$ Vid supra: sección 2.3.1.

225 Decisión de confirmación de cargos, ICC-01/05-01/08-424, The Prosecutor v. Jean-Pierre Bemba Gombo, Sala de Cuestiones Preliminares II, Corte Penal Internacional, 3 de julio de 2009, párr. 184.
} 
Polít. crim. Vol. 13, No 25 (Julio 2018) Art. 12, pp. 444-500.

[http://www.politicacriminal.cl/Vol_13/n_25/Vol13N25A12.pdf]

fuera de la República Democrática del Congo, en la vecina República Centroafricana. Si bien el condenado no tenía el control sobre la zona donde tenían lugar las operaciones, si podía controlar a los soldados del MLC a través de la cadena de mando que cumplía con sus órdenes. ${ }^{226}$

Finalmente, se exige también como cuarta condición que el superior tenga la capacidad material y directa de tomar las medidas para cumplir con sus obligaciones jurídicas. Este requisito plantea la cuestión sobre si la exigencia de tener capacidad "material y directa" excluye a los superiores militares que sin ser los mandos inmediatos de quienes comenten los crímenes, cuentan, sin embargo, con la capacidad material para tomar algunas de las medidas exigidas por el art. 28 ECPI. Como hemos visto, el DIP permite que la RespSup se extienda verticalmente en la cadena de mando, con tal de que los superiores de mayor rango, y generalmente más alejados de la escena de crimen, conserven su capacidad material para prevenir, reprimir o remitir el asunto a la autoridad competente. ${ }^{227}$

\subsection{El elemento objetivo: La omisión de la obligación jurídica del superior de adoptar todas las medidas razonables y necesarias a su disposición para prevenir, reprimir o enviar a la autoridad competente los crímenes de sus subordinados.}

Como hemos visto, el art. 24 transitorio del Acto Legislativo 01/2017 establece que la RespSup se fundamenta en los medios al alcance del superior para "prevenir que se cometa o se siga cometiendo la conducta punible, siempre y cuando las condiciones fácticas lo permitan, y de haber ocurrido, promover las investigaciones procedentes". La referencia a aquellos crímenes que están en proceso de ser cometidos o se están cometiendo, incluye la obligación de reprimir, lo que es coherente con el art. 28 ECPI. ${ }^{228}$ Así mismo, la referencia al deber de promover las investigaciones pertinentes parece incluir el ejercicio de los propios poderes disciplinarios y la obligación de remitir a la autoridad competente (esto es, a quien cuente con la capacidad de investigar y sancionar a los autores y participes de los crímenes) el asunto para su conocimiento. ${ }^{229}$

Ahora bien, para que este elemento conserve su coherencia con el DI, será necesario interpretar la expresión "medios a su alcance" como sinónimo de "todas las medidas necesarias y razonables", en el entendido de que, entre todas las medidas a su disposición, el superior debe adoptar aquellas que resulten idóneas para prevenir o reprimir la comisión de los crímenes y sean proporcionales a la amenaza que se pretende repeler. ${ }^{230}$

\subsection{El elemento subjetivo: la exclusión de la imprudencia simple del ámbito de aplicación de la Responsabilidad del Superior}

Respecto del elemento subjetivo, el art. 24 transitorio del Acto Legislativo 01/2017 dispone en su párrafo segundo, y en la última condición concurrente exigida para el control

\footnotetext{
${ }^{226}$ OSPINA, "Situación en África Central” Cit. nota. $\mathrm{n}^{0} 147, \mathrm{p} .162$.

227 Vid supra: sección 2.3.1.

${ }^{228}$ Sentencia de Primera Instancia, ICC-01/05-01/08-3343, The Prosecutor v. Jean-Pierre Bemba Gombo, Sala de Primera Instancia III, Corte Penal Internacional, 21 de marzo de 2016, párr. 201.

${ }^{229}$ Vid supra: sección 2.3.2.

230 Vid supra: sección 2.3.2.
} 
OLASOLO, Héctor; CANOSA, Jannluck. "La Responsabilidad del Superior en el Acuerdo de Paz en Colombia a la luz del Derecho Internacional".

efectivo, que la RespSup se funde "en el conocimiento basado en la información a su disposición antes, durante o después de la realización de la respectiva conducta" y en "el conocimiento actual o actualizable" del que disponga el superior.

Este estándar se encuentra estrechamente relacionado con el recogido en la expresión "conocía o tenía razones para saber", que, como hemos visto, se incluye en los arts. 7(3) ETIPY, 6 (3) ETIPR y 6 (3) ECESL. Sin embargo, excluye el estándar de imprudencia simple recogido en la expresión "hubiere debido saber" que, según el art. 28(a)(i) ECPI, es aplicable a los superiores militares. Como hemos visto, este último estándar exige una actitud proactiva del superior militar para informarse acerca de las actividades de sus subordinados $\mathrm{y}$, en caso de que dicha información alerte objetivamente sobre la posibilidad de que los subordinados estén preparando, o cometiendo, crímees internacionales, adoptar las diligencias de investigación necesarias para esclarecer esta situación. ${ }^{231} \mathrm{Si}$ bien se podría argumentar que el estándar "tenía razones para saber" es parte de la DI consuetudinario, no es menos cierto que Colombia se ha obligado de manera voluntaria a implementar en su legislación interna el estándar de imprudencia simple previsto en el art. 28 ECPI. $^{232}$

\subsection{La inexistencia de un vínculo de causalidad entre la omisión de los superiores y los crímenes de los subordinados.}

El art. 24 transitorio del Acto Legislativo 01/2017 no recoge referencia alguna en la definición de la RespSup al vínculo de causalidad entre la omisión del superior y los crímenes de sus subordinados. De esta manera, parece que se ha optado por seguir lo dispuesto en los estatutos y jurisprudencia del TIPY, el TIPR y la CESL, en detrimento de la regulación contenida en el art. 28 ECPI. Como hemos visto, no es este el único elemento en el que el art. 24 transitorio acoge esta posición.

La ausencia de este vínculo de causalidad parece alejar la RespSup prevista en el art. 24 transitorio, de la comisión por omisión, la autoría mediata por aparatos organizados de poder e incluso la complicidad por omisión (que como hemos visto es la naturaleza del incumplimiento del deber de prevenir en el art. 28 ECPI). En consecuencia, se podría entender que la naturaleza jurídica de la RespSup en el art. 24 transitorio es aquella de los delitos de omisión propia, en línea con lo establecido por la jurisprudencia del TIPY en lo casos Krnojelac, ${ }^{233}$ Halilovic $^{234}$ y Hadzihasanovic et al. ${ }^{235}$

\footnotetext{
231 Decisión de confirmación de cargos, ICC-01/04-01/06-803-tEN, The Prosecutor v. Thomas Lubanga Dyilo, Sala de Cuestiones Preliminares I, Corte Penal Internacional, 7 de febrero de 2007, párr. 434.

${ }^{232}$ Ley 742 de 2002. Por medio de la cual se aprueba el Estatuto de Roma de La Corte Penal Internacional, hecho en Roma el día diecisiete (17) de julio de mil novecientos noventa y ocho (1998). Diario Oficial de la República de Colombia, No. 44826 de 7 de junio de 2002.

${ }^{233}$ Sentencia de la Sala de Apelación, IT-97-25, The Prosecutor v. Krnojelac, Tribunal Penal Internacional para la ex Yugoslavia, 17 de septiembre de 2003, párr. 171.

${ }^{234}$ Sentencia Sala de Primera Instancia, IT-01-48, The Prosecutor v. Halilovic, Tribunal Penal Internacional para la Ex Yugoslavia, 16 de noviembre de 2005, párrs. 75-78.

235 Sentencia de Primera Instancia, IT-01-47, The prosecutor v. Hadzihasanovic \& Kubura, Tribunal Penal Internacional para la Ex Yugoslavia, 15 de marzo de 2006, párr. 38-42.
} 
Polít. crim. Vol. 13, № 25 (Julio 2018) Art. 12, pp. 444-500.

[http://www.politicacriminal.cl/Vol_13/n_25/Vol13N25A12.pdf]

Por eso, resulta, cuando menos, desconcertante que al mismo tiempo que el legislador colombiano ha adoptado esta aproximación, exija elementos como el control efectivo del superior sobre la específica conducta punible del subordinado, que van exactamente en la dirección contraria, al tratarse de elementos propios de ciertas formas de autoría, que requerirían en todo caso la existencia de un vínculo de causalidad entre la omisión del superior y los crímenes de los subordinados.

\subsection{La ausencia de referencia a los superiores civiles.}

Para finalizar nuestro análisis del art. 24 transitorio del Acto Legislativo 01/2017, es importante subrayar que en el mismo se limita el ámbito de aplicación de la RespSup a quienes ostentan la condición de superiores de la Fuerza Pública, es decir militares o policiales. Con ello se deja por fuera uno de los elementos más importantes de la definición de la RespSup en los arts. 28 ECPI, 7(3) ETIPY, 6 (3) ETIPR y 6 (3) ECESL, como es la extensión de su ámbito de aplicación a los superiores civiles.

Esta omisión es particularmente más grave porque las pocas referencias existentes en el Derecho y la jurisprudencia colombianos a la RespSup limitan su aplicación a los superiores militares. En consecuencia, se corre el riesgo de generar un amplio espacio de impunidad con respecto a miles de autoridades civiles que, como reflejan las más de dieciséis mil solicitudes de investigación (compulsas de copia) emitidas por la jurisdicción de Justicia y Paz a la Fiscalía General de la Nación durante la última década, omitieron durante años el cumplimiento de sus deberes ante la comisión de crímenes internacionales por sus subordinados.

\section{Conclusiones}

La comparación realizada en el presente trabajo entre la regulación de la RespSup en el DI, en particular en el DIP, y su tratamiento en el Derecho colombiano, con particular atención al Acuerdo y al Acto Legislativo 01/2017, nos ha permitido identificar toda una serie de diferencias, que son especialmente significativas en lo que se refiere a su aplicación a los agentes del Estado. Varias de estas diferencias son idóneas para generar importantes espacios de impunidad con respecto a los superiores militares y civiles que incumplen sus obligaciones de prevenir, reprimir o someter a la autoridad competente los crímenes internacionales por los que son responsables sus subordinados.

Ante esta situación, presentamos en esta sección final de conclusiones un conjunto de propuestas dirigidas a reducir estos espacios de impunidad, en el entendido de que, de no abordarse adecuadamente los problemas identificados, corresponderá a la Fiscalía de la CPI determinar si procede la apertura de una investigación sobre la situación en Colombia cuyo fin seria adelantar actuaciones penales contra aquellos agentes del Estado que sean considerados "máximos responsables" de genocidio, crímenes de lesa humanidad y crímenes de guerra, y en especial, como la Fiscal de la CPI reiteraba el 9 de julio de 2017, de aquellas ejecuciones extrajudiciales denominadas "falsos positivos".

Las propuestas presentadas se pueden clasificar en tres grupos, según se refieren a las fuentes normativas de la RespSup, sus elementos y su ámbito de aplicación. En cuanto a las 
OLASOLO, Héctor; CANOSA, Jannluck. "La Responsabilidad del Superior en el Acuerdo de Paz en Colombia a la luz del Derecho Internacional".

primeras, es importante tener en cuenta que la naturaleza constitucional atribuida al art. 24 transitorio del Acto Legislativo 01/2017 genera un conflicto normativo entre las reglas del DI integradas en la Constitución de Colombia a través del Bloque de Constitucionalidad y la norma en mención que se desvía del mismo en varios aspectos sustanciales. Sólo la resolución de este conflicto de manera que se faculte a la JEP para aplicar la normativa internacional, y en particular el art. 28 ECPI, permitiría resolver los problemas identificados en este trabajo sin necesidad de recurrir a reformas legislativas. Con ello, además, se superarían los problemas generados por la prohibición de aplicar las reglas operacionales de la Fuerza Pública que sean contrarias a la "normatividad legal", cuando estas se ajusten al tratamiento internacional de la RespSup, como es, en buena medida, el caso del Manual MFE 6-27 sobre Derecho Operacional Terrestre. De no acogerse esta interpretación, las reformas legislativas serán imprescindibles.

Como hemos visto, el chapeau del art. 24 transitorio prevé que, para determinar la RespSup entre los mandos de la Fuerza Pública colombiana, la JEP deberá aplicar el Código penal. Sin embargo, este último no recoge la RespSup, y los intentos de la CCC y la SCPCSJ por equipararla con la comisión por omisión y la autoría mediata por aparatos organizados de poder restringen de manera muy significativa su ámbito de aplicación. En consecuencia, el legislador debería regular expresamente en el Código penal colombiano la RespSup, tal y como se define en el art. 28 ECPI, incluyendo su extensión a los superiores civiles. A falta de esta medida, la propia jurisprudencia de la JEP debería afirmar la naturaleza autónoma de la RespSup como forma de responsabilidad penal, y la imposibilidad de subsumir la misma en las figuras de la comisión por omisión o la autoría mediata por aparatos organizados de poder.

Por su parte, en lo que se refiere a la aplicación del DIH como ley especial, la JEP debería interpretar esta remisión en el sentido de recurrir al DIH, no para desplazar al DIDH, sino para incrementar su grado de protección en determinadas situaciones dentro del conflicto armado.

Nuestro segundo grupo de propuestas se refiere a los elementos que configuran la RespSup, puesto que hemos identificado en el presente trabajo varios aspectos en que la regulación contenida en el Acuerdo y el Acto Legislativo 01/2017 se desvía significativamente de su tratamiento en el DI, y en particular en el art. 28 ECPI. En consecuencia, ya sea a través de las correspondientes reformas legislativas, ya sea por vía jurisprudencial apoyándose en la figura del Bloque de Constitucionalidad, es necesario corregir estas desviaciones, especialmente cuando restringen de manera muy notable el ámbito de aplicación de la RespSup y generan con ello importantes espacios de impunidad.

En primer lugar, el DIP es enfático en subrayar que la relación superior-subordinado sólo exige el control efectivo del superior sobre las unidades subordinadas que planean o llevan a cabo los crímenes, no sobre la conducta punible como tal. Este último tipo de control es propio de ciertas formas de autoría (como la autoría mediata), pero no de la RespSup que en el DI se configura como un delito de omisión propia o, en el caso del incumplimiento de la obligación de prevenir, como una forma de participación por complicidad dolosa o imprudente. De ahí, la necesidad de eliminar, o al menos inaplicar jurisprudencialmente, la referencia en el art. 24 transitorio al requisito del "control efectivo de la respectiva 
Polít. crim. Vol. 13, № 25 (Julio 2018) Art. 12, pp. 444-500.

[http://www.politicacriminal.cl/Vol_13/n_25/Vol13N25A12.pdf]

conducta", así como a las cuatro condiciones concurrentes que según dicha disposición deben darse para que pueda afirmarse la existencia de control efectivo.

En segundo lugar, con respecto al elemento objetivo de la RespSup, la expresión "medios a su alcance" recogida en el art. 24 transitorio, debe interpretarse como sinónimo de "todas las medidas necesarias y razonables", en el entendido de que, entre todas las medidas a su disposición, el superior sólo debe adoptar aquellas que resulten idóneas para prevenir o reprimir la comisión de los crímenes y sean proporcionales a la amenaza que se pretende repeler.

En tercer lugar, en relación con el elemento subjetivo de la RespSup, parece necesario incluir legislativa o jurisprudencialmente el estándar de imprudencia simple recogido en la expresión "hubiera debido saber" del art. 28 (a)(i) ECPI. Como hemos visto, este estándar castiga el incumplimiento por parte de los superiores militares de su obligación de mantener una actitud proactiva para informarse acerca de las actividades de sus subordinados y - en caso de que dicha información alerte objetivamente sobre la posibilidad de que sus subordinados estén preparando, o cometiendo, crímenes internacionales -, adoptar las diligencias de investigación necesarias para esclarecer dicha situación.

En cuarto lugar, el art. 24 transitorio no requiere un vínculo de causalidad entre la omisión del superior y los crímenes de sus subordinados, adoptando de esta manera la regulación prevista en los estatutos y jurisprudencia del TIPY, el TIPR y la CESL, en detrimento de la regulación contenida en el art. 28 ECPI. Como se trata de una aproximación más amplia a la RespSup, que tienen un fuerte anclaje en su actual regulación en el DIP, no parece problemático mantener la misma. Ahora bien, conviene no olvidar que su adopción supone renunciar a la configuración de la RespSup como un supuesto de complicidad por omisión dolosa o imprudente, puesto que esta última requiere que el incumplimiento del superior tenga un efecto favorecedor de la conducta punible de los subordinados. De esta manera, la RespSup en el art. 24 transitorio se presenta como un delito de omisión propia, en línea con lo establecido por la jurisprudencia del TIPY en los casos Krnojelac, ${ }^{236}$ Halilovic $^{237}$ y Hadzihasanovic et al. ${ }^{238}$

Finalmente, nuestro tercer grupo de propuestas se refiere a la necesidad de equiparar el ámbito de aplicación de la RespSup en el Acuerdo y el Acto Legislativo 01/2017 con el que presenta en los arts. 28 (b) ECPI, 7 (3) ETIPY, 6 (3) ETPIR y 6(3) ETIPR. Para ello es imprescindible que se extienda por vía legislativa o jurisprudencial su ámbito de aplicación a los superiores civiles. De lo contrario, se estaría preservando la impunidad de miles de superiores civiles, que como reflejan las más de dieciséis mil solicitudes de investigación emitidas por la Jurisdicción de Justicia y Paz a la Fiscalía General de la Nación en la última década, podrían ser responsables, conforme al tratamiento de la RespSup en el DIP, por los crímenes internacionales cometidos por sus subordinados.

\footnotetext{
${ }^{236}$ Sentencia de la Sala de Apelación, IT-97-25, The Prosecutor v. Krnojelac, Tribunal Penal Internacional para la ex Yugoslavia, 17 de septiembre de 2003, párr. 171.

${ }^{237}$ Sentencia Sala de Primera Instancia, IT-01-48, The Prosecutor v. Halilovic, Tribunal Penal Internacional para la Ex Yugoslavia, 16 de noviembre de 2005, párrs. 75-78.

238 Sentencia sala de primera instancia, IT-01-47, The prosecutor v. Hadzihasanovic \& Kubura, Tribunal Penal Internacional para la Ex Yugoslavia, 15 de marzo de 2006, párrs. 38-42.
} 
OLASOLO, Héctor; CANOSA, Jannluck. "La Responsabilidad del Superior en el Acuerdo de Paz en Colombia a la luz del Derecho Internacional".

\section{Bibliografía}

29 generales y coroneles, en la mira de la CPI por ejecuciones extrajudiciales [en línea], El Espectador. 9 de Julio de 2017. [Fecha de consulta: 19 de julio de 2017]. Disponible en_http://colombia2020.elespectador.com/jep/29-generales-y-coroneles-en-la-mirade-la-cpi-por-ejecuciones-extrajudiciales.

ABELLO, Ana, "El 'margen protector' de la Corte Penal Internacional", Anuario Iberoamericano de Derecho Internacional Penal, Vol. 4, (2015), pp. 124-144.

ACEVEDO, Juan, "La Responsabilidad del Superior 'sensu estricto' por Crímenes de Guerra en el Derecho Internacional Contemporáneo" Revista International Law, Vol. 10 (2007), pp. 153-198.

AMBOS, Kai, "Superior Responsibility", en CASSESE, Antonio, GAETA, Paola y JONES, John (Eds.), The Rome Statute of The International Criminal Court: A Commentary, Vol. 3, Oxford: Oxford University Press, 2002, pp. 823-872.

APONTE, Alejandro, "El Sistema Interamericano de Derechos Humanos y el Derecho Internacional Humanitario: una relación problemática", en GRUPO LATINOAMERICANO DE ESTUDIOS SOBRE DERECHO PENAL INTERNACIONAL, Sistema Interamericano de Protección de los Derechos Humanos y Derecho Penal Internacional, Montevideo: Fundación Konrad-Adenauer, 2010, pp. 125-170.

BANTEKAS, Illias, "The Contemporary Law of Superior Responsibility", American Journal of International Law, Vol. 93, No.3 (1999), pp. 573-595.

BASSIOUNI, Mahmoud Cherif, International Criminal Law, Vol III, 3 ed, Leiden: Martinus Nijhoff Publishers, 2008.

BENSOUDA, Fatou, El acuerdo de paz de Colombia demanda respeto pero también responsabilidad [En línea], 21 de enero de 2017, disponible en: 
Polít. crim. Vol. 13, № 25 (Julio 2018) Art. 12, pp. 444-500.

[http://www.politicacriminal.cl/Vol_13/n_25/Vol13N25A12.pdf]

http://www.semana.com/nacion/articulo/deseo-corte-penal-internacional-justiciatransicional-en-colombia/512820. [Fecha de consulta: 04/08/2017].

BORELLI, Silvia, "The (Mis)-Use of General Principles of Law: Lex Specialis and the Relationship between International Human Rights Law and the Laws of Armed Conflict" en PINESCHI, Laura (Ed.), General Principles of Law - The Role of the Judiciary. Heildelberg: Springer, 2015, pp. 265-295.

CARNERO, Enrique, “The Strugar Case before the International Criminal Tribunal for the Former Yugoslavia", Journal of International Law of Peace and Armed Conflict, Vol. 2 (2005), pp. 139-145, pp. 140-142.

CENTRO NACIONAL DE MEMORIA HISTÓRICA, ;Basta ya! Colombia: Memorias de guerra y dignidad resumen [en línea]. Colombia: Centro Nacional de Memoria Histórica, 2014 [fecha de consulta: 14/08/2017]. Disponible en https://www.centrodememoriahistorica.gov.co/descargas/informes2013/bastaYa/resu men-ejecutivo-basta-ya.pdf.

CHEVALIER, Juliet, "Has human rights law become lex specialis for the European Court of Human Rights in right to life cases arising from internal armed conflicts", The International Journal Of Human Rights, Vol. 14, Issue 4 (2010), pp. 584-602.

Colombia: ganó el "NO" en el plebiscito por los acuerdos de paz con las FARC [en línea]. BBC Mundo. 2 de octubre de 2016. [Fecha de consulta: 23 de julio de 2017]. Disponible en http://www.bbc.com/mundo/noticias-america-latina-37537187.

CONSEJERÍA PRESIDENCIAL PARA LOS DERECHOS HUMANOS, Estrategia Nacional para la Garantía de los Derechos Humanos 2014-2034, Bogotá: Imprenta Nacional, 2015.

COTE, Gustavo, "Responsabilidad del superior jerárquico y responsabilidad penal por omisión de miembros de la fuerza pública en Colombia: ¿convergencia entre el derecho penal nacional e internacional?" Revista Colombiana de Derecho Internacional, Vol 28 (2016), pp. 49-112.

Críticas de Human Rights Watch por cambios de última hora en el acuerdo [En línea]. El Espectador. 24 de noviembre de 2016. [Fecha de consulta: 21 de agosto de 2017]. Disponible en http://www.elespectador.com/noticias/paz/criticas-de-human-rightswatch-cambios-de-ultima-hora-e-articulo-667296.

CUERVO, Jorge; BECHARA, Eduardo; HINESTROZA, Verónica, Justicia transicional: modelos y experiencias internacionales. A propósito de la ley de justicia y paz, Bogota: Universidad Externado de Colombia, 2007.

DAMASKA, Mirjan, "The Shadow Side of Command Responsibility", The American Journal of Comparative Law, Vol. 49 (2001), pp. 455-496 
OLASOLO, Héctor; CANOSA, Jannluck. "La Responsabilidad del Superior en el Acuerdo de Paz en Colombia a la luz del Derecho Internacional".

DOWER, John, War without Mercy: Race and Power in the Pacific War, New York: Pantheon Books, 2012.

ECKHARDT, William, "Command Criminal Responsibility: A Plea for a Workable Standard”. Military Law Review, Vol. 97, (1982), pp. 1-58,

Educación, en la base de nueva estrategia del Ejército. El tiempo. 11 de junio de 2015. [Fecha de consulta: 19 de julio de 2017]. Disponible en http://www.eltiempo.com/archivo/documento/CMS-15935355.

EJÉRCITO NACIONAL DE COLOMBIA, Los derechos humanos y el derecho internacional humanitario. Hoja de ruta del Ejército Nacional, Bogotá: Editorial Ejército Nacional de Colombia, 2009.

EJÉRCITO NACIONAL DE COLOMBIA, Manuales Fundamentales de Ejército [En línea], 20 de diciembre de 2016. [Fecha de consulta: 13 de agosto de 2017]. Disponibles en https://ejercito.mil.co/centro_educacion_militar/examenes_competencia/manuales_fu ndamentales_ejercito_407139.

EJÉRCITO NACIONAL DE COLOMBIA, MFE 6-27 Derecho Operacional Terrestre [En línea], 20 de diciembre de 2016. [Fecha de consulta: 13 de agosto de 2017]. Disponibles https://ejercito.mil.co/centro_educacion_militar/examenes_competencia/manuales_fu ndamentales ejercito 407139.

FUNDACIÓN IDEAS PARA LA PAZ, Especial: Los debates sobre justicia transicional [En línea], 2015, disponible en http://www.ideaspaz.org/especiales/justiciatransicional/farc/descargas/plantillaGuion1.pdf. [Fecha de consulta: 14/08/2017].

GARROCHO, Ana, La Responsabilidad del Superior por Omisión en Derecho Penal Internacional, Navarra: Thomson Reuters, 2016.

GOBIERNO DE COLOMBIA Y FARC-EP, Acuerdo Final para la Terminación del Conflicto de una Paz Estable y Duradera, firmado el 24 de voviembre de 2016. Disponible en:https://www.mesadeconversaciones.com.co/sites/default/files/acuerdofinal-1473286288.pdf [Fecha de consulta: 23/07/2017].

GOBIERNO DE COLOMBIA, Aplicación de la Jurisdicción Especial para la Paz a los agentes del Estado. 19 de diciembre de 2015. Disponible en http://es.presidencia.gov.co/saladeprensa/Documents/JEP\%20para\%20agentes\%20del \%20Estado\%20.pdf. [Fecha de consulta: 14/08/2017].

HENCKAERTS, Jean; DOSWALD-BECK, Louise (Dirs.), El derecho internacional humanitario consuetudinario, Ginebra: CICR, 2007. 
Polít. crim. Vol. 13, № 25 (Julio 2018) Art. 12, pp. 444-500.

[http://www.politicacriminal.cl/Vol_13/n_25/Vol13N25A12.pdf]

JIA, Bing, "The Doctrine of Command Responsibility: Current Problems", Yearbook of International Humanitarian Law, Vol. 3 (2000), pp. 131-165.

KARSTEN, Nora, "Distinguishing Military and Non-military Superiors: Reflections on the Bemba Case at the ICC", J Int Criminal Justice, Vol. 7(5) (2009), pp. 983-1004.

KEITH, Kirsten, "The Mens Rea of Superior Responsibility as Developed by ICTY Jurisprudence", Leiden Journal of International Law, Vol. 14, Issue 3 (2001), pp. 617-634

KISS, Alejandro, "Command Responsibility under Article 28 of Rome Statute", en STAHN, Carsten (Ed.), The Law and Practice of the International Criminal Court, Oxford: Oxford University Press, 2014, pp. 608-648.

KISS, Alejandro, "La responsabilidad penal del superior ante la Corte Penal Internacional", Zeitschrift fur Internationale Strafrechtsdogmatik, Vol, 2016-1, (2016), pp. 40-66.

LANDRUM, Bruce, "The Yamashita War Crimes Trial: Command Responsibility Then and Now", Military Law Review, Vol. 149 (1995), pp. 293-301.

LEGMANN, Christof. ICC Chief Prosecutor Bensouda Threatens With Intervention in Colombia [en linea], NSNBC. 27 January 2017. [Fecha de consulta: 13 de agosto de 2017]. Disponible en https://nsnbc.me/2017/01/27/icc-chief-prosecutor-bensoudathreatens-intervention-in-colombia/.

LOYO, Joana, "La justicia transicional en Colombia: ¿Un instrumento creado para erradicar la impunidad?" Anuario Iberoamericano de Derecho Internacional Penal, Vol. 5, (2017), pp. 32-61.

MELONI, Chantal, "Command Responsibility: Mode of Liability for the Crimes of Subordinates or Separate Offence of the Superior?", Journal of International Criminal Justice,Vol. 5 (2007), pp. 616-637.

MILANOVIC, Marko, “The lost origins of lex specialis: rethinking the relationship between human rights and international humanitarian law" en OHLIN. Jens, Theoretical boundaries of armed conflict and human rights, Cambridge: Cambridge University Press, 2016, pp. 78-117.

MINISTERIO DE DEFENSA DE COLOMBIA, Política Integral de DDHH y DIH [En línea], 2008, disponible en https://www.fac.mil.co/sites/default/files/Politica DDHH MDN.pdf. [Fecha de consulta: 14/08/2017].

NYBONDAS, Maria, "Civilian Superior Responsibility in the Kordic Case", Netherlands International Law Review, Vol. 50, Issue 1, (2003), pp 59-82. 
OLASOLO, Héctor; CANOSA, Jannluck. "La Responsabilidad del Superior en el Acuerdo de Paz en Colombia a la luz del Derecho Internacional".

OFICINA DE LA FISCAL DE LA CPI, Informe sobre Exámenes Preliminares, situación en Colombia [En línea], 2016, disponible en https://www.icccpi.int/iccdocs/otp/161114-otp-rep-PE-Colombia.pdf, [fecha de consulta: 14/08/2017].

OLASOLO, Héctor, Tratado de Autoría y Participación en Derecho Penal Internacional, Valencia: Tirant lo Blanch, 2013.

OSPINA, Camila; CANOSA, Jannluck, "Situación en África Central, caso del Fiscal contra Jean Pierre Bemba Gombo, Sentencia conforme al artículo 74 del ECPI, ICC-01/0501/08, de 21 de marzo de 2016" [Reseña], Anuario Iberoamericano de Derecho Internacional Penal, Vol. 5 (2016), pp. 158-168.

PARKS, William, "Command Responsibility for War Crimes", Military Law Review, vol. 62 (1973), pp. 1274-1304

PILLOUD, Claude; SANDOZ, Yves; SWINARSKI, Christophe; y ZIMMERMANN, Bruno (eds.), Commentary on the Additional Protocols: of 8 June 1977 to the Geneva Conventions of 12 August 1949, La Haya: ICRC/ Martinus Nijhoff Publishers, 1987.

PRÉVOST, Ann Marie, "Race and War Crimes: The 1945 War Crimes Trial of General Tomoyuki Yamashita”, Human Rights Quarterly, vol. 14(3), (1992), pp. 303-338.

ROBINSON, Darryl, "How Command Responsibility Got So Complicated: A Culpability Contradiction, Its Obfuscation, and a Simple Solution", Melbourne Journal of International Law, Vol. 13, Issue 1 (2012), pp. 1-58

RONEN, Yael, "Superior Responsibility of Civilians for International Crimes Committed in Civilian Settings [article]", Vanderbilt Journal Of Transnational Law, Vol. 43, Issue 2 (2010). pp. 313-356.

ROXIN, Claus, Autoría y Dominio Del hecho en Derecho Penal, Madrid: Marcial Pons, 2016.

SALMON, Elizabeth, "Institutional Approach between IHL and IHRL: Current trends in the jurisprudence of the Inter-american Court of Human Rights" Journal of International Humanitarian Legal Studies, Vol. 5, Issue 1-2 (2014), pp. 152-185.

SCHABAS, William, "General Principles of Criminal Law in the International Criminal Court Statute, Part III", European Journal of Crime, Criminal Law and Criminal Justice, Vol. 6, Issue 4 (1988), pp. 84-112.

SCHABAS, William, An Introduction to International Criminal Law 3ed, Cambridge: Cambridge University Press, 2007.

SUELT, Vanessa, "El Bloque de Constitucionalidad como mecanismo de interpretación constitucional. Aproximación a los contenidos del Bloque en derechos en Colombia", Vniversitas, Vol. 65, Núm. 133 (2016), pp. 302-381 
Polít. crim. Vol. 13, № 25 (Julio 2018) Art. 12, pp. 444-500.

[http://www.politicacriminal.cl/Vol_13/n_25/Vol13N25A12.pdf]

Un mico en el acuerdo [En línea]. La Patria. 27 de noviembre de 2016. [Fecha de consulta: 21 de agosto de 2017]. Disponible en http://www.lapatria.com/nacional/un-mico-enel-acuerdo-332510.

VAN SLIEDREGY, Elies, The Criminal Responsibility of Individuals for Violations of International Humanitarian Law, La Haya: TMC Asser Press, 2007.

Vivanco está "decepcionado" por cambio en Acuerdo de Paz [En línea]. El Tiempo. 25 de noviembre de 2016. [Fecha de consulta: 4 de agosto de 2017]. Disponible en http://www.eltiempo.com/politica/proceso-de-paz/vivanco-esta-decepcionado-porcambio-en-acuerdo-final/16759214\#sthash.ZoWnDHKW.dpuf.

VIVANCO, Jose Miguel, Carta sobre "responsabilidad de mando" en la legislación de implementación del acuerdo de paz [En línea], 25 de enero de 2017, disponible en https://www.hrw.org/es/news/2017/01/25/carta-sobre-responsabilidad-de-mando-enla-legislacion-de-implementacion-del-acuerdo [fecha de consulta: 14/08/2017].

VOLKER, Nerlich, "Superior Responsibility under Article 28 ICC Statute", Journal of International Criminal Justice, Vol. 5, Issue 3, (2007), pp. 665-682.

WERLE, Gerhard, Principles of international criminal law, La Haya: TMC Asser press, 2005.

WERLE, Gerhard, Tratado de Derecho Penal Internacional, 2ed, Valencia: Tirant lo Blanch, 2011.

WILLIAMSON, Jamie, "Command Responsibility in the Case Law of the International Criminal Tribunal for Rwanda", Criminal Law Forum, Vol. 13, Issue 3 (2002), 